KaRen NogueIRA ChINOCA ZIZA

\title{
Determinação do genótipo RHD fetal no plasma materno: acurácia do teste semiautomatizado
}

Dissertação apresentada à Faculdade de Medicina da Universidade de São Paulo para a obtenção do título de Mestre em Ciências

Programa de Obstetrícia e Ginecologia

Orientador: Prof. Dr. Adolfo Wenjaw Liao

São Paulo 2015 


\section{Dados Internacionais de Catalogação na Publicação (CIP)}

Preparada pela Biblioteca da

Faculdade de Medicina da Universidade de São Paulo

Creprodução autorizada pelo autor

\section{Ziza, Karen Nogueira Chinoca}

Determinação do genótipo RHD fetal no plasma materno : acurácia do teste semi-automatizado / Karen Nogueira Chinoca Ziza. -- São Paulo, 2015.

Dissertação(mestrado)--Faculdade de Medicina da Universidade de São Paulo. Programa de Obstetrícia e Ginecologia.

Orientador: Adolfo Wenjaw Liao.

Descritores: 1.Técnicas de genotipagem 2.Sangue fetal 3.Sistema do grupo sanguíneo Rh-Hr 4.DNA/análise 5.Sensibilidade e especificidade 6.Diagnóstico pré-natal/métodos

USP/FM/DBD-391/15 
A Deus, meu Senhor e Salvador, que me concedeu saúde, garra e perseverança, e me ensina que pela Graça do AMOR é possível ultrapassar qualquer obstáculo.

A todas as mães $R h D$ negativo e seus filhos que, de forma generosa, participaram e acreditaram neste estudo. 
AGRADECIMENTOS 
A Deus, que nesta trajetória tão sonhada, me concedeu saúde física, emocional e espiritual. Que, com seu amor de PAI, me ensina que não há bem maior do que levar a esperança ao irmão.

A Minha Mãe, Nossa Senhora Aparecida, minha intercessora junto ao PAl, que me ensina com sua doçura, viver a obediência e a fidelidade da fé.

Aos meus amados pais, Maria Enedina Nogueira Chinoca e Nicolino Chinoca, os quais tiveram como missão gerar a minha vida e foram com grande êxito, meus primeiros professores, que sempre incentivaram meus estudos, pois acreditam que a educação é o melhor caminho.

Ao meu grande amor, João Paulo Ziza, que faz da minha vida uma alegria constante, pelo seu amor, companheirismo, paciência, sabedoria, generosidade e por me ensinar, a cada dia, que devemos levar a esperança em DEUS por meio de um sorriso, um olhar, uma palavra, um ouvir a todos que estão a nossa volta.

As minhas queridas irmãs, Deise Bilotti e Núbia Nogueira Chinoca, pela verdadeira amizade fraterna, que sempre me incentivaram a nunca desistir dos meus sonhos.

In memoriam, a minha vovó, Cecília Coelho Chinoca que, com sua doçura e alegria, sempre me incentivou a estudar. 
Aos meus sogros, Márcia e João Ziza, aos meus cunhados Cristiano Nunes, Fabiano Mello, Cláudia Ziza, ao meu primo Juliano Chinoca e a todos os meus familiares, que muito me apoiaram e incentivaram nesta trajetória.

Ao meu excelentíssimo Prof. Dr. Adolfo Wenjaw Liao, que me orientou neste estudo e, com muita paciência e sabedoria (científica e humana), me ensinou clinicamente a olhar e zelar por uma pequena vida, o qual fez grande diferença no meu desempenho laboratorial. Pela sua amizade e pelas suas palavras de conforto nos momentos mais difíceis.

Ao meu excelentíssimo Prof. Dr. José Eduardo Levi, que teve como missão me orientar na parte laboratorial, com seu amor incansável pela pesquisa, me ensinou a ter um olhar científico e crítico, o que me fez crescer como aluna. Pela sua amizade, e por acreditar e confiar no meu potencial como pesquisadora.

Ao digníssimo Prof. Dr. Marcelo Zugaib, Professor Titular de Obstetrícia do Departamento de Obstetrícia e Ginecologia da Faculdade de Medicina da Universidade de São Paulo, por abrir as portas da disciplina, e acreditar que a parte laboratorial pode contribuir grandemente para a Clínica Obstétrica.

À Profa. Dra. Maria de Lourdes Brizot, uma das grandes incentivadoras deste projeto que, com sua generosidade e conhecimento científico, me ensinou clinicamente a ter um cuidado e zelo com as gestantes aloimunizadas. Pelas suas palavras firmes e pontuais na 
qualificação, que efetivamente fez um diferencial para a conclusão deste estudo.

À Profa. Dra. Mariza Mota, pela sua disponibilidade, atenção e contribuições valiosas na fase de qualificação.

Ao Prof. Dr. Mário Henrique Burlacchini, pela atenção e apontamentos enriquecedores na fase de qualificação.

Ao Dr. Paulo Chinen, membro suplente na fase de qualificação, pela sua disponibilidade, generosidade e contribuição científica em relação ao tema, e apontamentos essenciais a este estudo.

À Dra. Lisandra Stein Bernardes Ciampi de Andrade, membro suplente na fase de qualificação, pela disponibilidade e atenção.

À Profa. Dra. Rossana Pulcineli Francisco, coordenadora da PósGraduação do Departamento de Obstetrícia, pela oportunidade de desenvolver este estudo na Clínica Obstétrica.

Às Dras. Renata Almeida de Assunção, Marcela Vieira Xavier Campos e Estela Naomi, por me acolherem, de forma carinhosa, no Ambulatório, pelos ensinamentos clínicos e pela agradável convivência e amizade.

Às Dras. Sandra Frankfurt Centofanti, Mariana Yumi Miyadahira, Sckarlet Biancolin, Ellen Beatriz A. Freire, pela amizade, incentivo e apoio.

A todos os professores e médicos assistentes da Clínica Obstétrica, pela generosidade, apoio e convivência. 
Às Sras. Evangelina Gomes, Josefa Marinho, Maria das Graças Silva e Maria do Carmo Neves, funcionárias do ambulatório da Clínica Obstétrica, pela amizade, carinho, incentivo e apoio na etapa da coleta.

Ao Sr. Amadeu Ferreira dos Santos, funcionário do Hospital das Clínicas, pela amizade, carinho, incentivo e apoio na etapa da coleta.

Às Sras. Lucinda Pereira, Soraia Silva, Raquel Cândido, Célia Nunes e Marina Silva, secretária e funcionárias administrativas da Clínica Obstétrica, pela acessibilidade e boa vontade.

Aos digníssimos Prof. Dr. Dalton de Alencar Fischer Chamone e Profa. Dra. Sandra Fatima Menosi Gualandro, do Departamento de Hematologia e Hemoterapia da Faculdade de Medicina da Universidade de São Paulo, pela oportunidade e apoio a este projeto.

Aos meus chefes do laboratório de Imuno-hematologia Clínica, Serviço de Hematologia e Hemoterapia do Hospital das Clínicas da Universidade de São Paulo, Eduardo Jens, Thiago Pagliarini e Anderson Carvalho, pela generosidade de permitirem minha ausência no setor para execução do trabalho, além do incentivo, apoio e amizade.

Aos meus companheiros do laboratório de Imuno-hematologia Clínica Marilene Pajzos, Lucélia Marques, Rosely Tokuho, William Medici, Gustavo Ricci, Maricea Mitsue e Mônica Ahmed, pelo incentivo, apoio, amizade, e agradável e alegre convivência diária.

Ao Dr. Alfredo Mendrone Junior, diretor técnico-científico da Fundação Pró-Sangue, pela oportunidade de utilizar as instalações da Fundação Pró-Sangue, pela motivação e apoio à pesquisa científica. 
À Dra. Carla Luana Dinardo, chefe da divisão de Imuno-hematologia da Fundação Pró-Sangue, por permitir livre acesso ao Laboratório de Controle de Qualidade, pelo seu incentivo, apoio e ensinamentos científicos que me auxiliaram diretamente neste estudo.

Aos funcionários do Laboratório de Controle de Qualidade da Fundação Pró-Sangue, Silvana Navarro, Silvia Leão, Antônio Gallucci, Vitor Medeiros e Gláucia Pancev, pela disponibilidade e boa vontade.

À Juliana V. dos Santos Bianchi, pela amizade verdadeira, por sempre me motivar na carreira acadêmica e por ser responsável por apresentar meus atuais professores.

À Márcia Dezan, pela sincera amizade, pelo apoio e incentivo à pesquisa científica e por toda a ajuda na etapa final deste estudo.

Às companheiras Suzete Lombardi, Anna Nishiya, Claúdia Barreto e Cecília Alencar pesquisadoras da Fundação Pró-Sangue, pelos ensinamentos científicos, apoio, incentivo e amizade.

Ao Enfermeiro Aparecido Braz, pela amizade, incentivo, apoio e por ser o responsável por me ensinar a coleta da punção venosa.

A todas as gestantes RhD negativo e seus filhos, que participaram efetivamente deste trabalho, pela sua generosidade e compreensão de que, ao participar deste estudo, estariam levando a esperança a futuras mães, de um dia poderem descobrir a genotipagem $\mathrm{RhD}$ de seus filhos, de forma precoce, para aliviar seus corações de preocupações e aflições. 
AGRADECIMENTO FINANCEIRO 
À Fundação de Amparo à Pesquisa do Estado de São Paulo (FAPESP), sob processo de número FAPESP: 2012/00401-2, que apoiou este estudo financeiramente e acreditou na potencialidade como contribuição científica nacional e internacional. 
"A minha vocação é me doar, e por amor darei o meu melhor, pois o Senhor um dia me chamou quer que eu seja luz para as nações."

Pitter di Laura 
Esta dissertação está de acordo as seguintes normas, em vigor no momento desta publicação:

Referências: adaptado de International Committee of Medical Journals Editors (Vancouver).

Universidade de São Paulo. Faculdade de Medicina. Divisão de Biblioteca e Documentação. Guia de apresentação de dissertações, teses e monografias. Elaborado por Anneliese Carneiro da Cunha, Maria Julia de A. L. Freddi, Maria F. Crestana, Marinalva de Souza Aragão, Suely Campos Cardoso, Valéria Vilhena. 3a ed. São Paulo: Divisão de Biblioteca e Documentação; 2011.

Abreviaturas dos títulos dos periódicos de acordo com List of Journals Indexed in Index Medicus. 
LISTAS

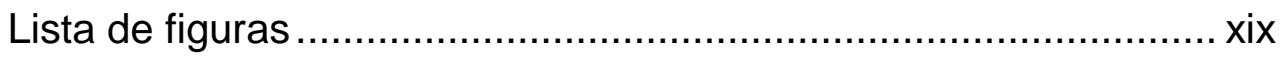

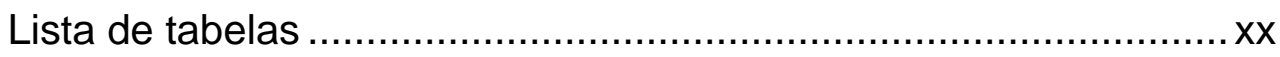

Lista de abreviaturas, símbolos e siglas...................................... Xxii

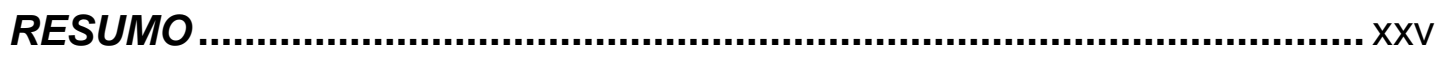

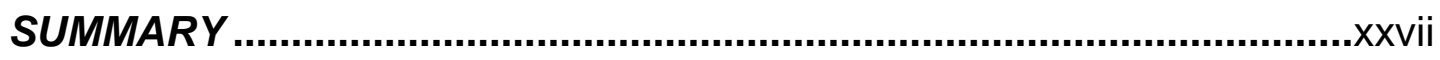

1 INTRODUÇÃO

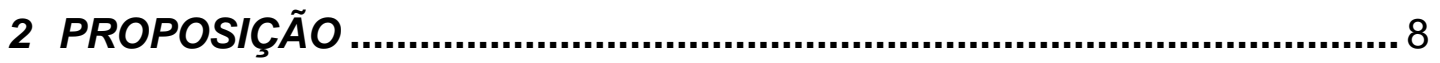

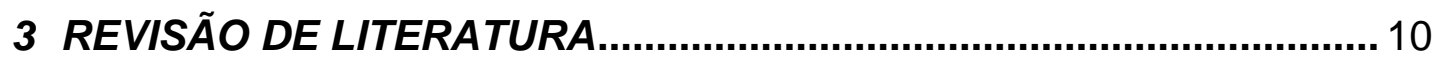

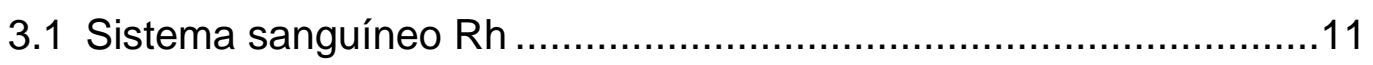

3.1.1 Estrutura molecular e proteica ........................................... 11

3.1.2 Antígeno RhD e principais alterações gênicas ................... 14

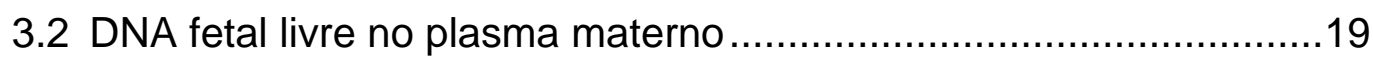

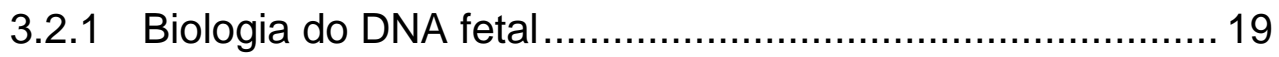

3.3 Teste de diagnóstico pré-natal não invasivo ...................................21

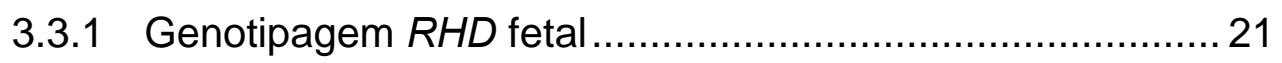

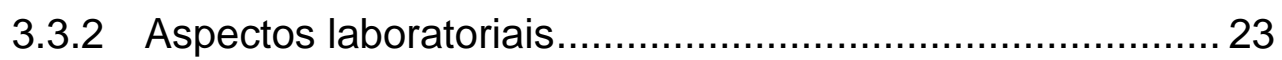

3.4 Acurácia do teste de genotipagem RHD fetal.................................31

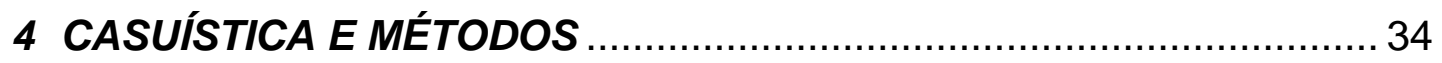

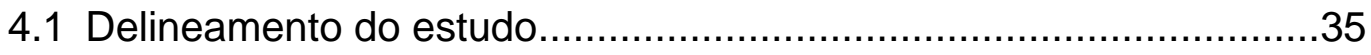

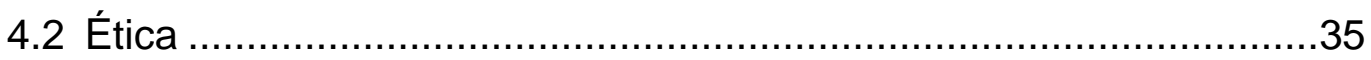

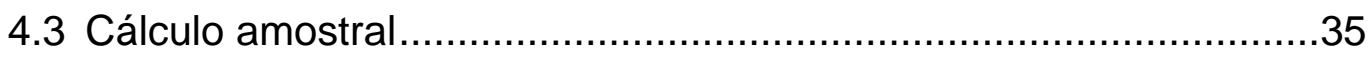

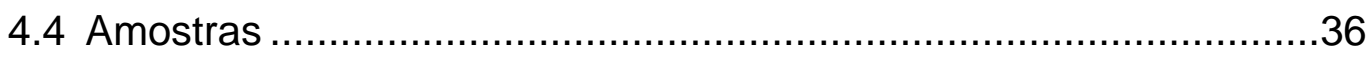

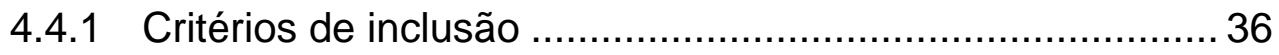

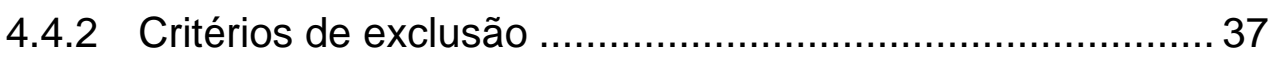

4.4.3 Recrutamento e identificação das gestantes ....................... 37

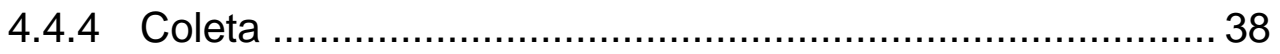

4.4.5 Processamento e Armazenamento ................................... 39

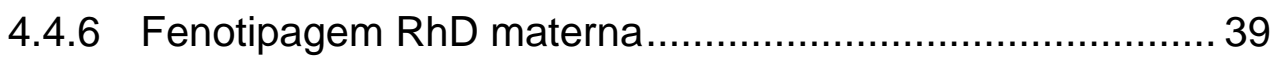

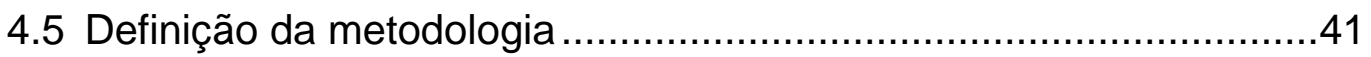

4.5.1 Método de extração ....................................................... 41 
4.5.2 Validação do equipamento ......................................42

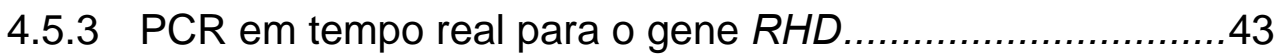

4.5.4 Controle de qualidade interno .....................................45

4.6 Desenho do estudo ............................................................46

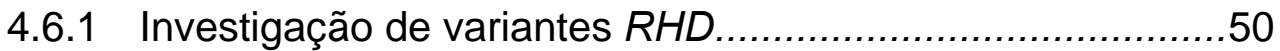

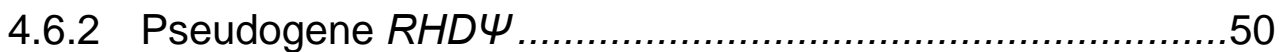

4.6.3 PCR multiplex $R H D$ parcial ......................................53

4.7 Fluxograma geral da metodologia ............................................5

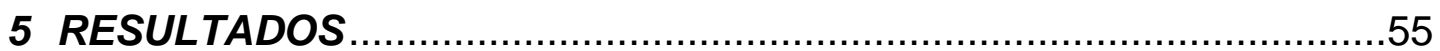

5.1 Características gerais da população ...........................................56

5.2 Resultados da PCR em tempo real para o gene RHD em comparação com o fenótipo RhD do recém-nascido.

5.3 Resultados das PCR em tempo real e PCR convencional para o gene $R H D$ nos casos inconclusivos

5.4 Custo do teste de genotipagem RHD fetal por método de extração automatizada .......................................................67

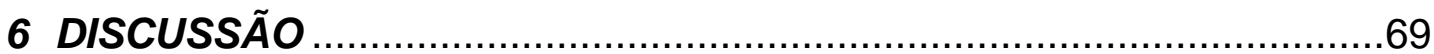

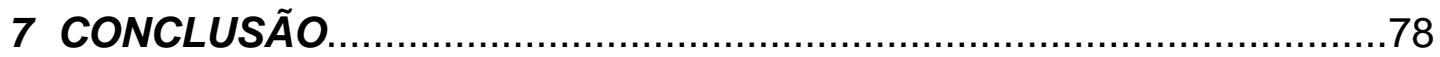

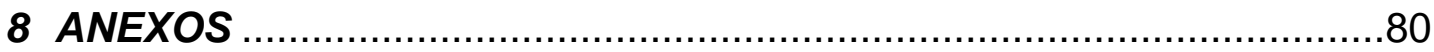

Anexo 1 - Aprovação da Comissão de Ética para Análise de Projetos de Pesquisa - CAPPesq ..................................................... 81

Anexo 2 - Termo de Consentimento Livre e Esclarecido .......................82

Anexo 3 - Ficha de Identificação ................................................. 85

Anexo 4 - Protocolo de reação..................................................... 86

Anexo 5 - Protocolo para exração de DNA - BRAZOL ...........................90

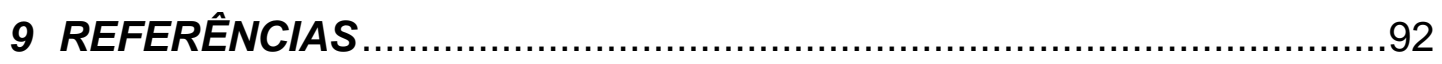

Apêndice 


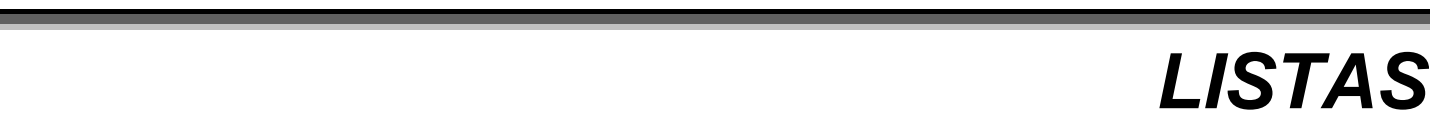




\section{LISTA DE FIGURAS}

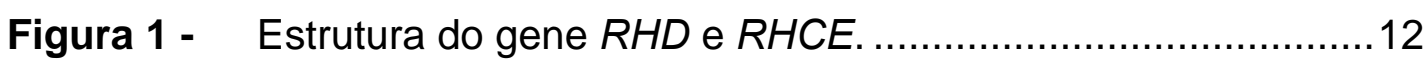

Figura 2 - Estrutura da Proteína Rh na membrana eritrocitária .............13

Figura 3 - Representação esquemática do locus Rh e principais alterações gênicas..................................................16

Figura 4 - $\quad$ Antígeno RhD e suas variantes fenotípicas........................18

Figura 5 - $\quad$ Representação esquemática da presença do DNA-FL na circulação materna. .................................................20

Figura 6 - Representação esquemática da PCR em tempo real.............28

Figura 7 - Princípio da extração realizada com o kit LV no equipamento automatizado MagNA Pure Compact...............43

Figura 8 - Exemplo de resultado apresentado na PCR em tempo real

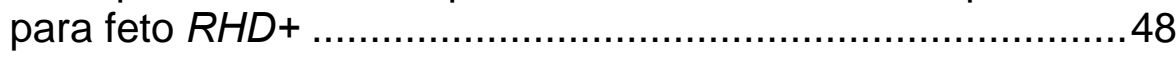

Figura 9 - Exemplo de resultado apresentado na PCR em tempo real para feto $R H D$ -

Figura 10 - Exemplo de resultado apresentado na PCR em tempo real para a variante RHD (mãe, feto ou ambos).

Figura 11 - Exemplo de resultado obtido na PCR em tempo real para determinar o $R H D \Psi$.

Figura 12 - Fluxograma geral do teste de genotipagem $R H D$ fetal...........54

Figura 13 - Ensaio da PCR convencional para o pseudogene $R H D \Psi \ldots \ldots 63$

Figura 14 - Multiplex $R H D$ parcial ............................................... 65

Figura 15 - Fluxograma do teste de genotipagem $R H D$ fetal para 0 acompanhamento das gestantes $\mathrm{RhD}$ negativo 


\section{LISTA DE TABELAS}

Tabela 1 - Acurácia das principais publicações realizadas no período de 1998-2014

Tabela 2 - Descrição dos primers e sondas do gene $R H D$, éxons 5 e 7

Tabela 3 - Resultados esperados para os éxons 5 e 7 com variantes silenciosas do gene RHD.

Tabela 4 - Descrição dos pares de primers e sonda do CCR5. 45

Tabela 5 - Metodologia do teste de genotipagem $R H D$ fetal, baseado em valores de cts e escores.

Tabela 6 - Descrição dos pares de primers e sonda do pseudogene $R H D \Psi$, em PCR em tempo real

Tabela 7 - Características gerais da população em estudo.

Tabela 8 - Resultados por classificação em escores, baseados na presença ou ausência de amplificação em comparação ao fenótipo do recém-nascido

Tabela 9 - Tabela de contingência das distribuições dos resultados das amplificações dos éxons 5 e 7 em relação ao fenótipo do recém-nascido.

Tabela 10 - Resultados comparativos entre genotipagem e fenotipagem e a distribuição das porcentagens na população em estudo.

Tabela 11 - Resultados encontrados entre gestantes aloimunizadas e não aloimunizadas em comparação ao genótipo RHD fetal.

Tabela 12 - Cálculo das sensibilidades (S), especificidades (E), valores preditivos positivos (VPP), valores preditivos negativos (VPN) e acurácia (A) dos resultados das amplificações dos éxons 5 e 7 em comparação aos trimestres gestacionais.

Tabela 13 - Resultados do ensaio do $R H D \Psi$ na PCR em tempo real por valores de amplificação, das amostras maternas comparadas ao fenótipo do recém-nascido 
Tabela 14 - Custo do teste de genotipagem RHD fetal por método de extração automatizada .................................................... 67

Tabela 15 - Custo dos testes imuno-hematológicos e profilaxia envolvidos no acompanhamento das gestantes $\mathrm{RhD}$

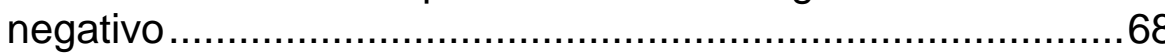




\section{LISTA DE ABREVIATURAS, SÍMBOLOS E SIGLAS}

\begin{tabular}{ll} 
AGH & Teste de antiglobulina humana \\
Amplicon & Produto amplificado \\
${ }^{\circ}$ C & Grau Celsius \\
anti-D & Anticorpo contra o antígeno D \\
CAPPesq & Comitê de Ética para Análise de Projetos de Pesquisa \\
CCR5 & Gene CCR5 \\
Ct & Cycle threshold \\
D fraco & Alelo D fraco \\
D parcial & Alelo D parcial \\
DVI & Antígeno RhD parcial categoria VI \\
dNTP & Desoxiribonucleotídeos \\
ddH2O & Água deionizada e destilada \\
DHPN & Doença Hemolítica Perinatal \\
DNA & Ácido desoxirribonucléico \\
DNA-FL & DNA Fetal Livre \\
EDTA & Ácido etilenodiamino tetra-acético \\
E & Especificidade \\
Epítopo & Local de ligação do anticorpo \\
Éxon & Região codificante do gene \\
FAPESP & Fundação de Amparo à Pesquisa do Estado de São Paulo \\
Fluoróforo & Componente da molécula que faz com que esta seja \\
FRET & fluorescente \\
GAPDH & Fluorescence resonance energy transfer \\
g & Gliceraldeído -3-fosfato desidrogenase \\
GEL & Força centrífuga \\
HC-FMUSP & Técnica de hemaglutinação em gel \\
IG & Hospital das Clínicas da Faculdade de Medicina da \\
IgG & Universidade de São Paulo \\
Íntron & Idade Gestacional \\
& Imunoglobulina Gamma \\
\hline
\end{tabular}




\begin{tabular}{|c|c|}
\hline $\mathrm{kpb}$ & Quilobase (corresponde a 1.000 pares de bases) \\
\hline Ladder & Marcador de peso molecular \\
\hline LISS & Solução de baixa força iônica \\
\hline LV & Large Volume \\
\hline $\mathrm{MgCl}^{2}$ & Cloreto de magnésio \\
\hline MGPS & Magnetic Glass Particles \\
\hline Missense & $\begin{array}{l}\text { Substituição de um par de bases por outro, codifica um } \\
\text { aminoácido diferente do original }\end{array}$ \\
\hline $\mathrm{mL}$ & Mililitro \\
\hline $\mathrm{mM}$ & Milimolar \\
\hline $\mathrm{N}^{\circ}$ & Número \\
\hline $\mathrm{NaCl}$ & Cloreto de sódio (Solução salina) \\
\hline $\mathrm{ng}$ & Nanogramas \\
\hline $\mathrm{nM}$ & Nanomolar \\
\hline Non-sense & $\begin{array}{l}\text { Substituição de um par de bases por outro, que gera um } \\
\text { códon de parada }\end{array}$ \\
\hline Primer & Sequência de oligonucleotídeos sintéticos \\
\hline $\mathrm{pb}$ & Pares de bases \\
\hline PCR & Reação em Cadeia da Polimerase \\
\hline RhAG & Antígeno RhAG \\
\hline$R H A G$ & Gene RHAG \\
\hline RHCE & Gene RHCE \\
\hline$R H D$ & Gene $R H D$ \\
\hline$R H D-C E-D^{S}$ & Gene híbrido $R H D-C E-D^{S}$ \\
\hline $\mathrm{RhD}$ & Antígeno RhD \\
\hline RhDEL & Fenótipo RhDEL \\
\hline RhD negativo & Indivíduos portadores do fenótipo RhD- \\
\hline RhD positivo & Indivíduos portadores do fenótipo RhD+ \\
\hline$R H D \Psi$ & $R H D$ pseudogene \\
\hline rpm & Rotação por minuto \\
\hline RN & Recém-nascido \\
\hline RNA & Ácido ribonucleico \\
\hline PAl & Pesquisa de anticorpos irregulares \\
\hline PCR & Polymerase Chain Reaction \\
\hline
\end{tabular}


SAFE

$\mathrm{S}$

SNP

$\mathrm{SIGH}$

Sonda

SUS

TA

Taq DNA

TCLE

TIU

TS

UV

uL

$\mu \mathrm{M}$

VPN

VPP
Special Advances in Fetal and Neonatal Evaluation

Sensibilidade

Polimorfismo de nucleotídeo único

Sistema de Informação e Gestão Hospitalar

Fragmento de DNA marcado para hibridizar outra molécula de DNA

Sistema Único de Saúde

Temperatura ambiente

Enzima termoestável com atividade polimerase

Termo de Consentimento Livre e Esclarecido

Transfusão Intrauterina

Tipagem sanguínea

Ultravioleta

Microlitros

Micromolar

Valor preditivo negativo

Valor predivo positivo 
RESUMO 
Ziza KNC. Determinação do genótipo RHD fetal no plasma materno: Acurácia do teste semiautomatizado [Dissertação]. São Paulo: Faculdade de Medicina, Universidade de São Paulo; 2015.

INTRODUÇÃO: A determinação do genótipo RHD fetal no plasma materno é um teste de diagnóstico pré-natal não invasivo oferecido a gestantes RhD negativo que apresentam potencial de sensibilização e/ou Doença Hemolítica Perinatal. Atualmente, este exame é realizado de rotina em diversos países, mas não no Brasil. A Clínica Obstétrica do Hospital das Clínicas da Faculdade de Medicina da Universidade de São Paulo (HCFMUSP) oferece atendimento terciário a gestantes RhD negativo, com monitorização dos títulos de anticorpos irregulares, administração da imunoglobulina anti-D e/ou terapêutica fetal, quando necessários. OBJETIVO: Avaliar a acurácia do teste semiautomatizado para determinação do genótipo RHD fetal no plasma materno. METODOLOGIA: Foram coletadas prospectivamente amostras de sangue de 220 gestantes RhD negativo, com idade gestacional entre 8-28 semanas. O plasma foi obtido em no máximo 2 horas após a coleta, e uma alíquota de $1 \mathrm{~mL}$ foi submetida à extração de ácidos nucléicos no equipamento automatizado MagNA Pure Compact (Roche), empregando o kit Large Volume. O DNA extraído foi submetido a PCR em tempo real (Step One Plus - Applied Biosystems), usando o protocolo do grupo $S A F E$, que tem como alvos os éxons 5 e 7 do gene RHD. RESULTADOS: Ocorreu exclusão de 35 amostras devido a problemas pré-analíticos, aborto ou desconhecimento do fenótipo do recém-nascido. Entre as 185 amostras analisadas, 130 (70,2\%) foram genotipadas como $R H D+$ e 55 (29,8\%) RHD-. Os resultados obtidos foram comparados com a fenotipagem do cordão umbilical, e houve concordância completa (100\%). Sete amostras exibiram amplificação exclusiva para o éxon 7. Essas amostras foram submetidas aos protocolos em PCR convencional, e PCR em tempo real específico para o pseudogene $R H D \Psi$. Ambos os ensaios apresentaram os mesmos resultados: cinco positivos e dois negativos. Nesses mesmos 7 casos, após extração da camada de leucócitos materna, os protocolos foram repetidos, e o resultado confirmou que cinco mães eram $R H D \Psi$. As duas amostras com resultado negativo foram submetidas ao protocolo Multiplex, envolvendo os éxons 3-9 do gene $R H D$, com resultados negativos, confirmando que as mães são verdadeiramente $R H D$ - portanto o sinal do éxon 7 é provindo dos fetos que são D variantes. CONCLUSÃO: O método para a determinação do $R H D$ fetal no plasma materno descrito demonstrou ser rápido, de fácil execução, alta precisão e reprodutível, além de indicar possíveis variantes $R H D$ em nossa população.

Descritores: Técnicas de genotipagem; Sangue fetal; Sistema do grupo sanguíneo Rh-Hr; DNA/análise; Sensibilidade e especificidade; Diagnóstico pré-natal/métodos. 
Ziza KNC. Fetal RHD genotype determination in maternal plasma: Accuracy of a semi-automated test [Dissertation]. São Paulo: "Faculdade de Medicina, Universidade de São Paulo"; 2015.

BACKGROUND: Fetal RHD genotype determination in maternal plasma is a noninvasive prenatal diagnostic test performed in $\mathrm{RhD}$ negative pregnant women at risk of alloimmunization and/or Hemolytic Disease of Fetus and Newborn. Currently, this test is routinely performed in many countries but not in Brazil. The Department of Obstetrics at Hospital das Clínicas, São Paulo University Medical School provides tertiary antenatal care for RhD negative pregnant women including anti-D immunoglobulin administration, antibody levels monitoring and intrauterine treatment if necessary. AIMS: To validate the accuracy of a semi-automated test for fetal RHD genotype determination in maternal plasma. METHODS: Two-hundred and twenty blood samples were prospectively collected between 8 and 28 weeks of gestational age. Plasma processing was performed within 2 hours after blood collection, and nucleic acids were extracted from $1 \mathrm{~mL}$ aliquots with an automated extraction platform (MagNA Pure Compact Roche) and the Large Volume kit. RHD gene exons 5 and 7 were amplified with real-time PCR (Step One Plus Applied Biosystems) using the SAFE group protocol. RESULTS: Thirty-five samples were excluded due to pre-analytical problems, miscarriage and missing follow-up. In the remaining 185 samples, 130 (70.2\%) were genotyped as RhD+ and 55 (29.8\%) RhD-. Comparison with umbilical cord blood group phenotype showed $100 \%$ concordance. Seven samples showed amplification for exon 7 only. These were further investigated with conventional and real-time PCR with an specific protocol for $R H D \psi$ pseudogene: 5 were positive and 2, negative. In these 7 cases, maternal buffy-coat DNA analysis also confirmed that 5 women were $R H D \psi$. In the remaining 2 cases, a multiplex protocol directed at RHD gene exons 3-9 confirmed that both mothers were truly RhD negative so exon 7 signal comes from the fetuses, further found to harbor D variants. CONCLUSION: The present study demonstrates that fetal $R H D$ determination in maternal plasma is a fast, easy-to-perform and reproducible technique with high accuracy in our population. Moreover, it helps in the identification of possible $R H D$ variants in our population.

Keywords: Genotyping techniques; Fetal blood; Rh-Hr Blood group system; DNA/analysis; Sensitivity and specificity; Prenatal diagnosis/methods. 
No período gestacional, a aloimunização materna é o fenômeno que leva à formação de anticorpos, após exposição a antígenos eritrocitários alogênicos, de origem paterna, presentes nas hemácias fetais ${ }^{1}$. Esses aloanticorpos da classe IgG atravessam a barreira placentária e destroem os eritrócitos fetais, levando à doença hemolítica perinatal (DHPN), condição marcada por anemia, icterícia, hidropsia, kernicterus, morte uterina e neonatal ${ }^{2}$.

A aloimunização é causada principalmente pelos antígenos do sistema sanguíneo Rh, que atualmente é composto por 54 antígenos ${ }^{3}$, mas, somente cinco estão envolvidos de forma clinicamente significante na DHPN $(\mathrm{D}, \mathrm{C}, \mathrm{C}, \mathrm{E}, \mathrm{e})^{4}$.

Os anticorpos Rh correspondem a $60 \%$ dos casos DHPN, nos países desenvolvidos ${ }^{5}$ e aproximadamente $95 \%$, nos países em desenvolvimento, incluindo o Brasil ${ }^{6}$. Entretanto, é notório que o antígeno RhD é o mais implicado nos casos de aloimunização, devido a sua maior imunogenicidade 6

No meio obstétrico, a aloimunização pelo antígeno $\mathrm{RhD}$, é caracterizada quando uma gestante $\mathrm{RhD}$ negativo é exposta a sangue fetal RhD positivo e desenvolve o anti-D ${ }^{2,7}$.

A Clínica Obstétrica do Hospital das Clínicas da Universidade de São Paulo (HC-FMUSP) é um centro de referência terciário do Sistema Único de Saúde (SUS). Em um estudo realizado durante o período de 2009 a 2013, foi observado que $21,1 \%$ das gestantes apresentavam algum tipo de 
aloanticorpo. Nelas, a frequência de anticorpos irregulares anti-D isolado foi de $42,1 \%$ e, associado com outros anticorpos, foi de $60,4 \%{ }^{8}$.

Atualmente, a frequência fenotípica do antígeno $\mathrm{RhD}$ negativo em caucasianos é entre $12-18 \%$, em negros, $8 \%$, em asiáticos, $0,3 \%{ }^{9}$. Na população brasileira, devido à grande miscigenação, essa frequência pode variar de acordo com a região, sendo a média do contingente entre $10^{10}$ $11,9 \%{ }^{11}$.

Se consideramos que $10 \%$ das gestantes brasileiras são $\mathrm{RhD}$ negativo, e que o número de nascidos vivos, em 2013, foi aproximadamente $3.000 .000^{12}$, cerca de 300.000 mulheres teriam risco potencial para a aloimunização.

Durante anos, a aloimunização RhD acarretou a DHPN e foi causa significativa de morbidade e mortalidade perinatal. No entanto, com a introdução da profilaxia (imunoglobulina anti-D), a partir da década de 1960, houve uma redução significativa da doença de $15 \%$ para $0,2 \%{ }^{7,13,14,15}$.

Atualmente, nos países desenvolvidos, a incidência da DHPN pelo anti-D é de aproximadamente 1 caso para 1.000 nascidos vivos, não sendo considerado, mais um problema de saúde pública ${ }^{7}$.

Entretanto, no Brasil, estudo realizado por Pacheco e colaboradores (2013) ${ }^{16}$ aponta que, entre 2007-2010, foram registrados, no Sistema de Informações Hospitalares do SUS (SIH/SUS) 14.345 internações de recémnascidos acometidos por DHPN-RhD. Essa taxa corresponde a uma incidência de 5 casos para 1.000 nascidos vivos. Foi observado que as regiões Sul e Sudeste respectivamente apresentam o maior número de 
internações, 2.405 e 7.746, e revelam uma incidência ainda maior (6,5 e 6,9 para 1.000 nascidos vivos) ${ }^{16}$.

A gravidade do cenário brasileiro não se deve apenas à doença ${ }^{16}$. Outros elementos colaboram para esse fato como a ineficiência na assistência ao pré-natal devido às oportunidades perdidas na administração da profilaxia, dificuldade de aquisição da profilaxia nas redes públicas de saúde, falta de conscientização das pacientes $\mathrm{RhD}$ negativo à sua condição de sujeitas a fatores de risco durante a gestação (como sangramentos e procedimentos invasivos), déficit de profissionais e serviços especializados ${ }^{16}$ e, por fim, o desconhecimento do genótipo $R H D$ fetal durante o pré-natal.

O conhecimento do genótipo $R H D$ fetal, durante a gestação, foi possível após a caracterização molecular dos genes do sistema Rh $(R H D$ e RHCE), em meados dos anos $90{ }^{17}$.

Presentemente, existem descritos três mecanismos genéticos associados ao fenótipo RhD negativo. Em caucasianos, ocorre a deleção total do gene RHD; em negros, ocorre mais comumente mecanismos genéticos de inserções e rearranjos gênicos como o pseudogene $R H D \Psi$ e genes híbridos $R H D^{*}-C E-D^{18}$; em asiáticos, por mecanismos genéticos de mutações de pontos, ocorre a expressão fraca do antígeno RhD, denominado $\mathrm{RhDEL}$, erroneamente enquadrado como $\mathrm{RhD}$ negativo ${ }^{19}$.

Dentre os indivíduos que expressam o antígeno $\mathrm{RhD}$, existem ainda variações no fenótipo dependentes de alterações de sua estrutura molecular, e são classificadas como D parcial, D fraco e DEL ${ }^{19}$. 
Contudo, no meio obstétrico, inicialmente, o teste de genotipagem $R H D$ fetal não teve aceitabilidade clínica, pelo fato de que o ácido desoxirribonucleico (DNA) ser proveniente de amniócitos, células trofoblásticas ou células fetais ${ }^{20}$, obtido por meio de procedimentos invasivos como amniocentese ou cordocentese. Tais procedimentos estão associados a perdas fetais e à hemorragia feto-materna ${ }^{5,21}$.

Porém, como já era almejado há muitos anos na Medicina Fetal, em 1997, o pesquisador Dennis Lo e colaboradores descobriram, de forma pioneira, a presença de DNA Fetal Livre no plasma materno (DNA-FL), o que permitiu a determinação não invasiva do genótipo $R H D$ fetal ${ }^{22}$.

Durante o período de 1997-2015, inúmeros estudos foram realizados para determinar a acurácia do teste de genotipagem $R H D$ fetal, aumentando gradualmente de $90 \%$ para $100 \%$, e garantindo um teste não invasivo altamente confiável ${ }^{23,24}$.

No entanto, para obter uma alta acurácia e garantir uma execução confiável, vários estudos enfatizam a relevância dos cuidados na fase préanalítica como: escolha do tubo, transporte, processamento, centrifugação e estoque ${ }^{25,26}$. Na fase analítica, a escolha do método de extração, a estratégia das regiões alvo e os controles internos, juntamente com a reação em cadeia da polimerase em tempo real (PCR em tempo real) são determinantes para o sucesso da genotipagem $R H D$ fetal ${ }^{25,26}$.

Primeiramente, o teste de genotipagem $R H D$ fetal ganhou ampla aceitação para o manejo das gestantes aloimunizadas ${ }^{27}$. 
Após a predição do genótipo fetal, nos casos de gestantes aloimunizadas pelo anti-D que confirmam que o feto é $R H D$ positivo, obrigase a fazer um acompanhamento intensificado com maior número de consultas e exames subsidiários como: Pesquisa de Anticorpos Irregulares (PAI), ultrassonografia e dopplerfluxometria e se necessário, a terapia fetal com Transfusão Intrauterina (TIU) e pós-natal com a realização da exsanguíneo transfusão ${ }^{28}$.

Nos casos de gestantes aloimunizadas pelo anti-D, com o feto $R H D$ negativo indica a ausência de risco para a DHPN, descaracterizando um acompanhamento de "alto risco", o que tranquiliza a mãe e seus familiares. Outros aspectos importantes são a diminuição de gastos com consultas, exames ultrassonográficos e laboratoriais, serviços e profissionais especializados, além de prevenir a prematuridade e a iatrogenia ${ }^{28}$.

Recentemente, o teste de genotipagem $R H D$ fetal tem sido introduzido na população de gestantes não aloimunizadas. Isso permite a administração seletiva da profilaxia em mulheres portadoras de fetos $R H D$ positivo, evitando a administração em mulheres portadoras de fetos $R H D$ negativo que não representam risco de DHPN ${ }^{29}$.

Desde 2011, países como Holanda e Dinamarca implantaram no programa do pré-natal o teste de genotipagem $R H D$ fetal para todas as gestantes RhD negativo ${ }^{30,31,32}$. Em 2014, países do Reino Unido e Suíça também iniciaram suas implantações ${ }^{33,34}$. 
No Brasil, o teste de genotipagem $R H D$ fetal é comercializado em poucos laboratórios particulares. Entretanto, ele não é aplicado em nenhum dos grandes centros obstétricos terciários do SUS.

Infelizmente, a ausência da aplicação do teste em nosso País se deve principalmente à dificuldade de incorporação de novas tecnologias relacionadas diretamente pelo custo e falta de mão-de-obra especializada. Ademais, um importante complicador é a intensa miscigenação da população brasileira que apresenta inúmeros polimorfismos dentro do sistema Rh.

Diante da realidade brasileira, em que a DHPN-RhD ainda é um problema de saúde pública e que a única forma de diminuição da incidência da doença é a prevenção, o propósito deste estudo é a determinação do genótipo $R H D$ fetal, por meio da padronização de uma metodologia laboratorial semiautomatizada, com alta performance, que identifique as principais variações gênicas, com baixo custo e que assegure para o médico obstetra um teste altamente confiável. 
O presente estudo tem como objetivo principal avaliar a acurácia do teste semiautomatizado para determinação do genótipo $R H D$ fetal no plasma materno.

São objetivos específicos:

1) Padronizar uma metodologia de extração automatizada para o teste de genotipagem $R H D$ fetal no plasma materno.

2) Apresentar uma nova metodologia de identificação para o pseudogene RHD $\Psi$ pela PCR em tempo real.

3) Identificar e diferenciar possíveis variantes $R H D$ nas amostras maternas ou fetais. 


\subsection{Sistema sanguíneo Rh}

\subsubsection{Estrutura molecular e proteica}

O sistema Rh é o maior e mais complexo de todos os sistemas de grupos sanguíneos ${ }^{9}$. Os antígenos são codificados pelos genes $R H D$ e RHCE. Esses genes apresentam 98\% de homologia e estão presentes no braço curto do cromossomo 1 (1p34.3-p36.1) ${ }^{35}$.

O gene $R H D$ codifica o antígeno $\mathrm{D}$ e o gene RHCE codifica os antígenos $\mathrm{C} / \mathrm{c}$ e $\mathrm{E} / \mathrm{e}^{9,36}$. Os genes $R H D$ e $R H C E$ contêm 10 éxons cada, distribuídos em 69 kilo pares de bases $(\mathrm{kpb})$ e possuem orientações opostas (5'RHD3' - 3'RHCE5') sendo o RHD codificado pela fita senso e o RHCE, pela fita antisenso ${ }^{9,36}$.

Os genes estão separados por aproximadamente $30 \mathrm{kbp} \mathrm{e}$, nessa região intergênica, encontra-se um gene TMEM50A, antigamente denominado de SMP1, que tem a mesma orientação do gene $R H D^{9,36}$.

O gene RHD está flanqueado por dois segmentos de DNA denominados "caixa Rhesus", com comprimento de $9 \mathrm{kbp}$, com mesma orientação ${ }^{37}$.

Wagner e Flegel (2000) ${ }^{37}$ estabeleceram a estrutura molecular do locus $R H$ e sugeriram que a caixa Rhesus contém a deleção do gene $R H D$ com 1,4 kpb de extensão e está presente na maioria dos indivíduos caucasianos $\mathrm{RhD}$ negativo. 
Em $2004{ }^{38}$ esses mesmos pesquisadores concluíram que o gene $R H D$ é o gene duplicado, enquanto os genes RHCE e TMEM50A são os genes ancestrais (Figura 1).

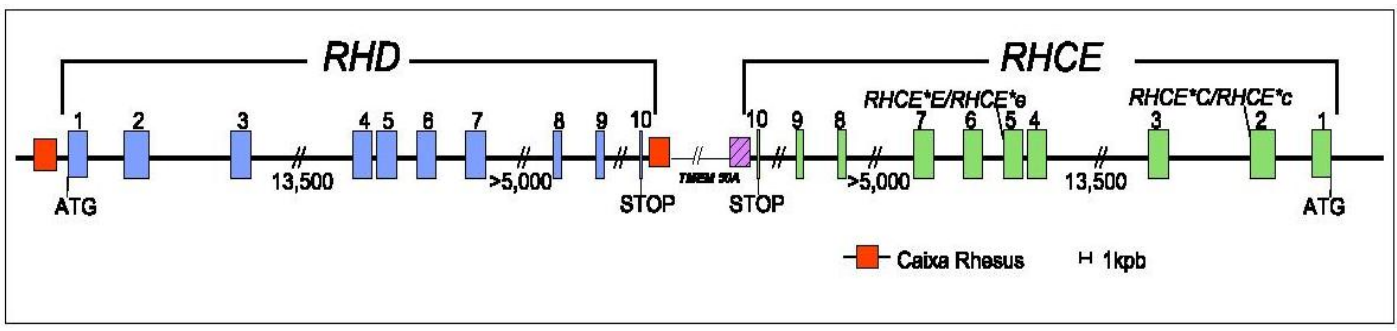

Figura 1 - Estrutura do gene RHD e RHCE

Cada quadrado equivale a um éxon. Em azul o gene $R H D$, em verde o gene RHCE. Cada gene apresenta 10 éxons, estão distribuídos em 69kbp e estão em direções opostas (5'RHD3' - 3'RHCE5'). Em vermelho, a caixa Rhesus que flanqueia o gene RHD. Em roxo, o gene TMEM50A. No éxon 2 e 5 do $R H C E$ apresentam-se os polimorfismos de nucleotídeo único (SNPs) que levam ao polimorfismo dos alelos C/c e E/e respectivamente (Adaptado de Reid, 2012) ${ }^{36}$.

A proximidade entre os genes $R H D$ e $R H C E$ facilita os processos de mutações como: crossing-over único, conversão gênica, modificação da proteína pós translocação e interação com outros genes ${ }^{39}$.

O sistema Rh é uma família de proteínas constituída pelos polipeptídios $\mathrm{RhD}$ e RhCE, sendo expressos exclusivamente na superfície do eritrócito ${ }^{9}$.

A expressão desses fenótipos deve-se à presença de três genes homólogos RHD, RHCE e RHAG. Este último está localizado no cromossomo 6 (6p21.3), tem 10 éxons distribuídos em $32 \mathrm{kpb}^{36,40}$.

As proteínas $\mathrm{Rh}$ formam um complexo com a glicoproteína RhAG firmemente ligado, ao citoesqueleto do eritrócito. Essa glicoproteína é primordial para a expressão dos antígenos Rh. A ausência dela pode levar 
ao fenótipo Rhnull caracterizado pela ausência da expressão de todos os antígenos $\mathrm{Rh}^{9,36}$.

As proteínas Rh são compostas por 417 aminoácidos e atravessam a membrana eritrocitária 12 vezes, apresentando os segmentos aminoterminal e carboxiterminal na face intracelular da membrana ${ }^{41}$.

Modelos estruturais atuais apresentam as proteínas Rh com 6 alças extracelulares, 12 transmembranares e 7 intracelulares ${ }^{42}$. As proteínas $\mathrm{RhD}$ e RhCE diferem em 32 a 35 aminoácidos dependendo do alelo RHCE considerado ${ }^{36}$ (Figura 2).

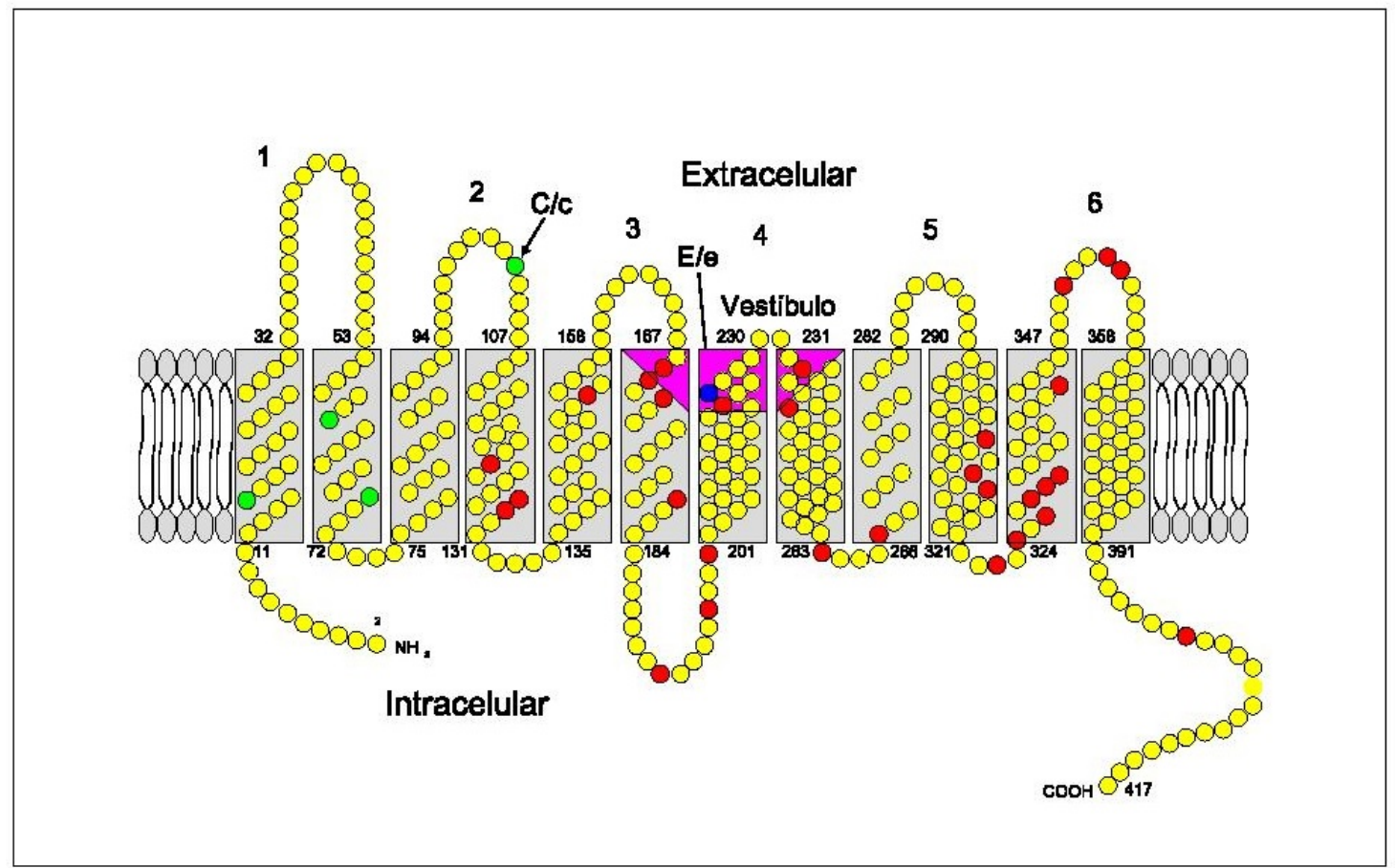

Figura 2 - Estrutura da Proteína Rh na membrana eritrocitária

Cada aminoácido é representado por um círculo. Os círculos em vermelho diferem a proteína RhD da RhCE. Os círculos em verde e azul representam os polimorfismos dos antígenos $\mathrm{C} / \mathrm{c}$ e E/e, respectivamente. Em rosa, a região do vestíbulo extracelular (Adaptado de Daniels, 2013) ${ }^{9}$. 


\subsubsection{Antígeno RhD e principais alterações gênicas}

Todo indivíduo herda uma cópia dos genes correspondentes às regiões $R H D$ e $R H C E$ de cada um dos seus progenitores.

O antígeno RhD é caracterizado por três situações: a presença de duas cópias do gene $R H D$, a de apenas uma cópia ou, em último caso, de nenhuma delas. As duas primeiras situações determinam o fenótipo RhD positivo, homozigoto ou heterozigoto, respectivamente. O terceiro caso está presente em indivíduos $\mathrm{RhD}$ negativo ou homozigotos para a deleção do gene $R H D^{43}$.

Os indivíduos caucasianos classificados como $\mathrm{RhD}$ negativo normalmente apresentam uma deleção completa do gene $R H D^{43,44}$.

Nos indivíduos negros, além da deleção, há duas variações genéticas, levando ao fenótipo RhD negativo, a saber: o Pseudogene $R H D \Psi$ possui uma inserção de 37 pares de bases $(\mathrm{pb})$ no éxon 4 do gene $R H D$ provindo do intron 3 , além de 3 mutações missense no éxon 5 (654G>C, 667T>G, 674C>T) e uma mutação pontual non-sense no éxon 6 $(807 T>G)$ que introduz um códon de parada ${ }^{45}$.

Singleton e colaboradores (2000) ${ }^{45}$, em seu estudo com indivíduos africanos RhD negativos, encontraram o $R H D \Psi$ em $66 \%$ de africanos oriundos de Zimbábue e Gana, 24\% de africanos americanos e em 17\% dos indivíduos da África do Sul. Na população brasileira, entre os indivíduos $\mathrm{RhD}$ negativo o estudo realizado por Rodrigues e colaboradores (2002) ${ }^{46}$ apontou essa variante genotípica com uma frequência de 11\%. Estudos 
mais recentes realizados na população de São Paulo indicaram uma frequência de $4,6 \%{ }^{11}$, e $3,18 \%{ }^{47}$.

Outra variante genotípica importante são os genes híbridos RHD-CE$D^{s}$ que estão presentes em indivíduos de origem caucasiana e africana.

O gene híbrido $R H D-C E(3-8)-D^{s}$ é composto pelos éxons 1,2 e extremidade 5 do éxon 3 do gene $R H D$, extremidade 3 do éxon 3 , éxon 4-8 do gene $R H C E$ e éxons 9 e 10 do gene $R H D^{43,45,}$. Os genes híbridos $R H D$ $C E(3-8)-D^{s}$ e o $R H D^{*} D-C E(3-7)-D$ são predominantemente encontrados em africanos ${ }^{45}$, enquanto que o gene $R H D^{*} D-C E(2-9)-D$ tem sido associado a populações europeias ${ }^{48}$.

O estudo realizado por Minon e colaboradores (2006) ${ }^{49}$ encontrou o gene RHD-CE-D em $22 \%$ da população africana, RhD negativo. No Brasil, Rodrigues et al. (2002) ${ }^{46}$ encontraram essa variante em $2 \%$ dos indivíduos RhD negativo. Em um estudo realizado com doadores de Sangue de São Paulo e Recife encontrou-se $0,16 \%{ }^{50}$.

Os indivíduos com a presença do $R H D \Psi$ e dos genes híbridos são classificados sorologicamente como RhD negativo, e não existe o risco de causarem aloimunização eritrocitária em receptores $\mathrm{RhD}$ negativo ${ }^{50}$ (Figura $3)$. 


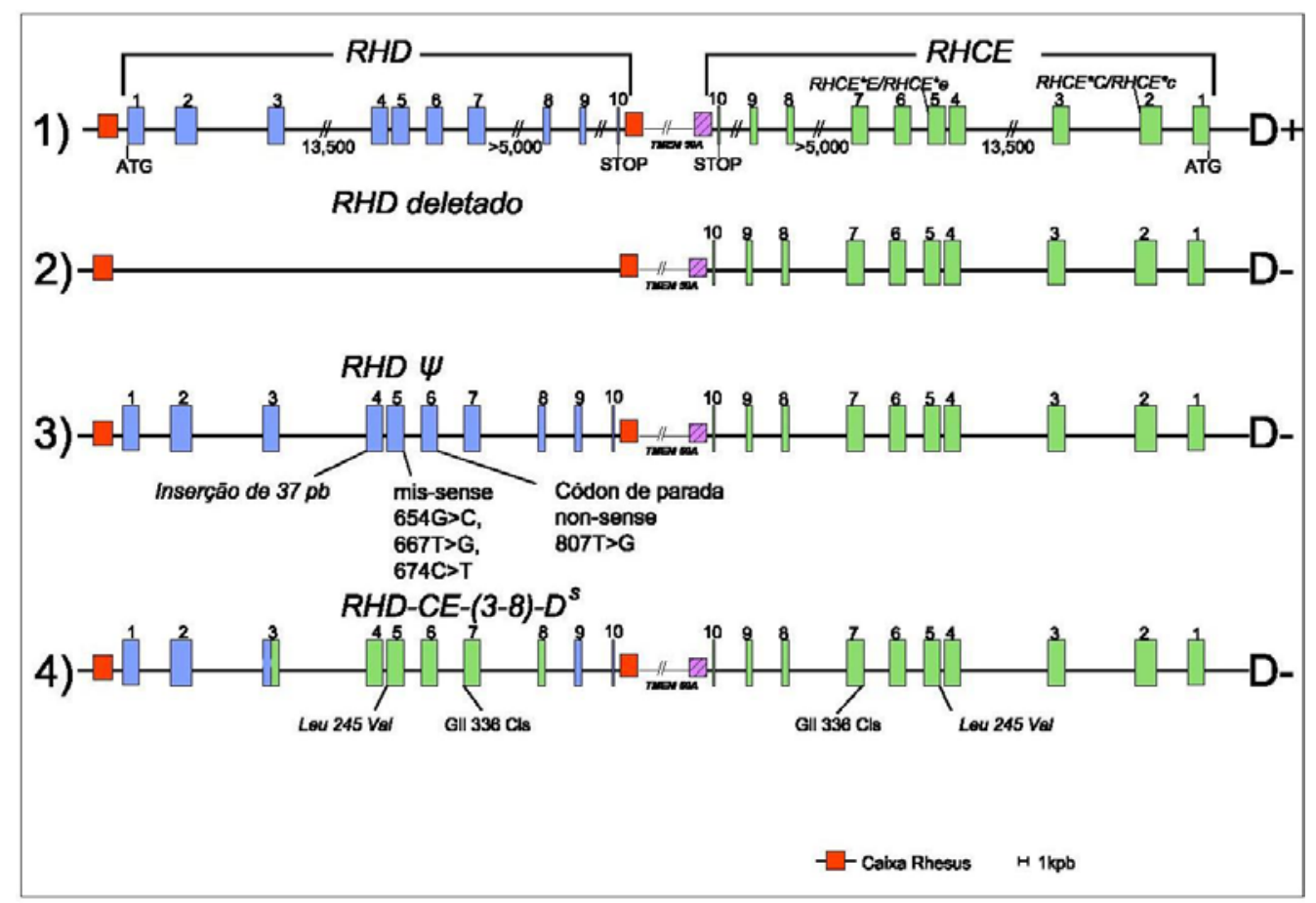

Figura 3 - Representação esquemática do locus Rh e principais alterações gênicas

1) Presença do gene $R H D$, indivíduo classificado como RhD positivo. 2) Deleção do gene $R H D$, indivíduo classificado com RhD negativo. 3) Presença do gene $R H D$, apresenta inserção de 37 pb no éxon 4, 3 mutações no éxon 5 (654G>C, 667T>G, $674 \mathrm{C}>\mathrm{T}$ ) e uma mutação pontual no éxon 6 (807T>G) que introduz um códon de parada, indivíduo classificado como $\mathrm{RhD}$ negativo (pseudogene $R H D \Psi$ ). 4) Presença do gene $R H D$, éxons 1,2 e extremidade 5 do éxon 3. Extremidade 3 do éxon 3, éxon 4-8 do gene RHCE. Éxons 9 e 10 do gene $R H D$, indivíduo classificado como $\mathrm{RhD}$ negativo (Gene híbrido RHD-CE(3-8)-D) ${ }^{s}$ (Adaptado de DANIELS, 2013) ${ }^{9}$.

O antígeno RhD é considerado como um mosaico composto de 37 epítopos que podem apresentar variação antigênica quantitativa ou qualitativa. Essas variações são denominadas de RhD fraco e RhD parcial e devem ser analisadas criteriosamente na determinação do fenótipo $\operatorname{RhD}^{9}$.

O fenótipo RhD fraco caracteriza-se pela diminuição quantitativa de epítopos no eritrócito. Dessa forma, laboratorialmente o antígeno RhD é detectado somente após a adição do soro de coombs (Antiglobulina 
Humana -AGH). Contudo, existem fenótipos RhD fraco que possuem baixíssima densidade antigênica e não são detectados na fase $\mathrm{AGH}^{9}$.

Atualmente, mais de 76 diferentes tipos de mutações associadas ao fenótipo RhD fraco já foram descritos ${ }^{18}$. Esses antígenos são expressos fracamente devido a SNPs que estão localizados nas regiões intracelulares e transmembranares da proteína $\mathrm{RhD}$. Esse fato explica a fraca expressão do antígeno RhD na membrana do eritrócito, assim como a ausência de aloanticorpo anti-D na maioria dos indivíduos $\mathrm{RhD}$ fraco ${ }^{37,51}$.

O fenótipo Del é um tipo de RhD fraco frequentemente encontrado em asiáticos. Caracteriza-se por uma densidade antigênica abaixo do nível de detecção dos reagentes anti-D disponíveis no mercado, sendo somente detectado com técnicas de adsorção e eluição. Dessa forma, indivíduos Del são classificados erroneamente como $\mathrm{RhD}$ negativo ${ }^{9,52}$.

O fenótipo RhD parcial caracteriza-se pela ausência qualitativa de epítopos devido a mutações ou rearranjos gênicos que alteram a sequência de aminoácidos em regiões extracelulares da proteína $\mathrm{Rh}^{9,36}$.

Atualmente mais de 88 tipos de RhD parcial foram descritos ${ }^{18}$. Essas mutações podem levar à formação de novos epítopos ou de epítopos alterados que podem ou não ser detectados pelos reagentes anti-D disponíveis no mercado. Diferentemente do fenótipo $\mathrm{RhD}$ fraco, indivíduos portadores do antígeno RhD parcial podem se aloimunizar quando expostos ao antígeno RhD normal que apresentam todos os epítopos. Além disso, na literatura, há relatos de indivíduos $\mathrm{RhD}$ parcial/fraco, os quais podem ser aloimunizados quando expostos ao antígeno RhD normal ${ }^{9}$. (Figura 4). 

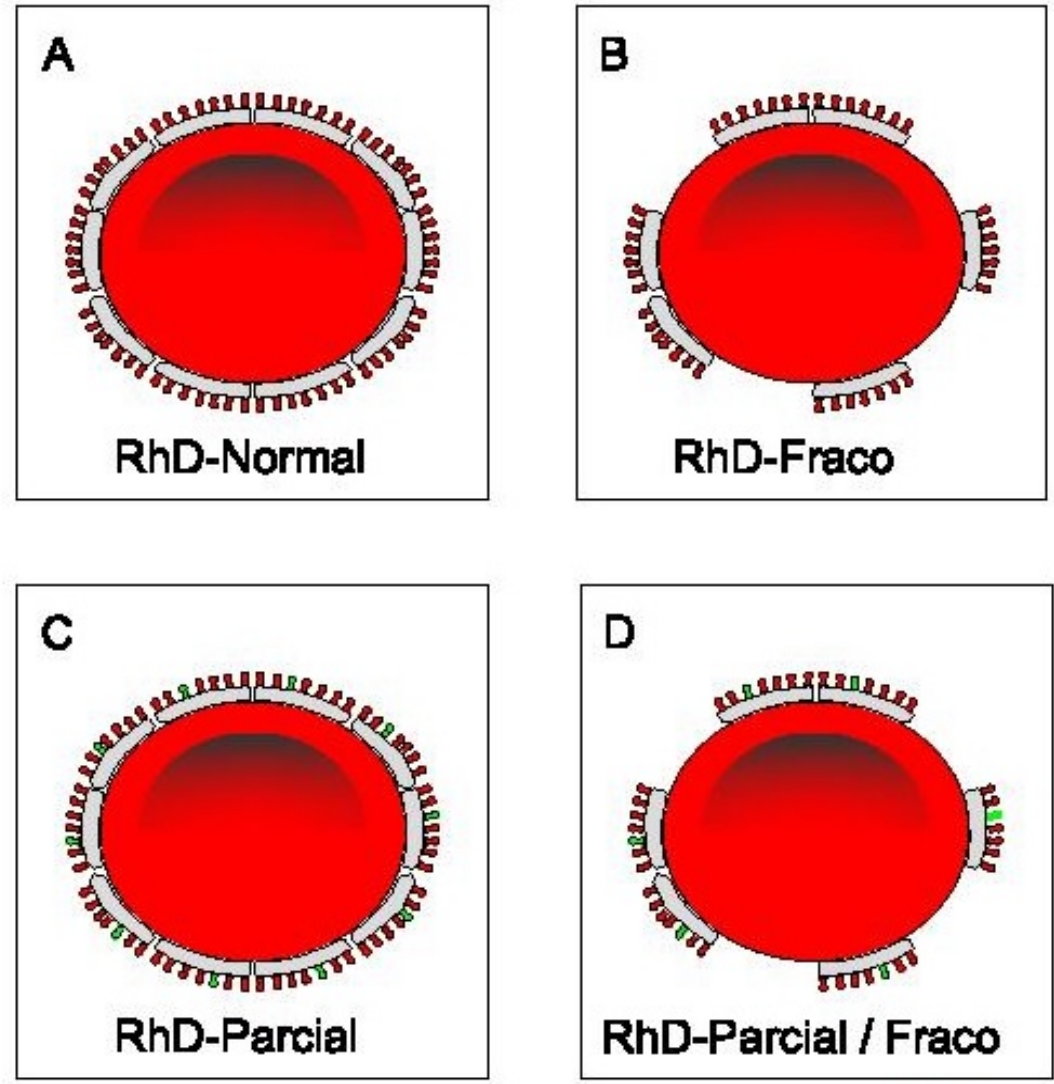

Legenda: Epltopo

Antigeno

Figura 4 - Antígeno RhD e suas variantes fenotípicas

A: RhD normal, com número adequado de antígenos e presença de todos os epítopos. B: RhD fraco, com quantidade reduzida de antígenos, porém, com todos os epítopos. C: RhD parcial, com quantidade normal de antígenos, porém, com um ou mais epítopos alterados em cada antígeno, representado pela cor verde. D: RhD parcial / fraco, com número reduzido de antígenos e com epítopos alterados nesses antígenos, representado pela cor verde.

A distinção sorológica entre os antígenos RhD fraco e RhD parcial de baixa densidade antigênica é muito difícil ${ }^{53}$. Apesar da grande variedade de soros monoclonais anti-D disponíveis, ainda se classificam alguns RhD parciais como RhD fracos. Portanto, essa diferenciação é importante, pois auxilia diretamente na conduta gestacional e transfusional ${ }^{54}$. 


\subsection{DNA fetal livre no plasma materno}

\subsubsection{Biologia do DNA fetal}

A presença de células nucleadas fetais na circulação materna foi hipotetizada, pela primeira vez, no século XIX, em meados de 1893, por Georg Schmorl quando observou essas células em parênquima pulmonar de mulheres com eclâmpsia ${ }^{55}$, porém sua existência foi comprovada somente no século $X X{ }^{56}$. Contudo, nenhum resultado prático foi encontrado uma vez que o isolamento dessas células é tecnicamente bastante complexo e sua quantidade na circulação materna é muito baixa ${ }^{57}$.

Em 1996, Bianchi e colaboradores ${ }^{57}$ demonstraram que essas células permanecem na circulação por muitos anos após o parto, e que isso poderia implicar em resultado falso-positivo em uma gestação subsequente.

No mesmo ano, Che e colaboradores ${ }^{58}$ demonstraram a existência de DNA tumoral livre no plasma de pacientes com doenças neoplásicas. Essa descoberta levantou a suspeita de que isso poderia ocorrer em outras situações biológicas em que DNA heterólogo pudesse ser encontrado na circulação.

A partir dessa hipótese, em 1997, o pesquisador Dennis Lo e sua equipe ${ }^{59}$ demonstraram, de forma pioneira, a presença de DNA-FL no plasma materno.

Em $1998^{22}$, o mesmo grupo concluiu que o DNA-FL é encontrado em quantidade relativamente grande, quando comparado com o pequeno 
número de células fetais circulantes, e que a proporção materno/fetal desse DNA aumenta com o progredir da idade gestacional.

Estudos evidenciaram que o DNA-FL é originado da apoptose das células do sinciciotrofoblasto placentário ${ }^{60}$. Isso foi demonstrado por Alberry e colaboradores (2007) ${ }^{61}$ em um estudo com gestações anembrionadas (presença do saco gestacional e trofoblasto, sem o feto), em que os níveis de DNA-FL não diferem daqueles encontrados em gestações normais no primeiro trimestre.

O DNA-FL é altamente fragmentado e possui aproximadamente 200 pb, muito pequeno quando comparado ao materno ${ }^{62,63}$ (Figura 5).

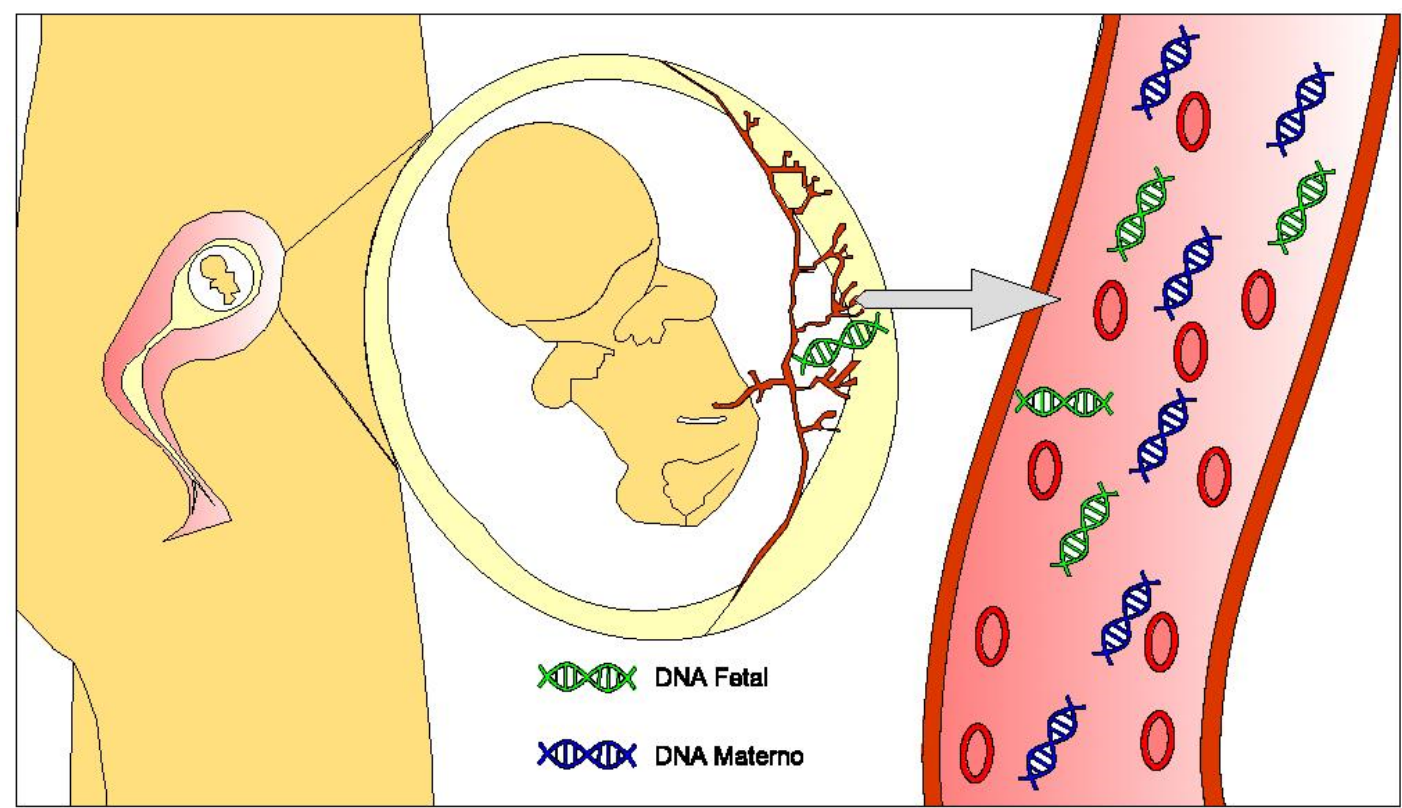

Figura 5 - Representação esquemática da presença do DNA-FL na circulação materna

O DNA fetal é proveniente da apoptose das células do sinciciotrofoblasto placentário e alcança a corrente sanguínea materna por meio do cordão umbilical. E possível observar que a proporção do DNA fetal livre é menor do que o DNA livre materno. 
Segundo Lo et al. (1997) ${ }^{59}$, os níveis desse DNA aumentam de acordo com a idade gestacional, sendo que ele representa aproximadamente $3,4 \%$ a $6,2 \%$ no primeiro e terceiro trimestre, respectivamente. Estudos posteriores estimaram que esse DNA fragmentado está em níveis de aproximadamente 25 cópias $/ \mathrm{mL}$ no primeiro trimestre ${ }^{22}, 32$ cópias/mL no segundo trimestre ${ }^{64}$, e uma média de 100 cópias/mL no terceiro trimestre ${ }^{26}$.

Zhou et al. (2005) ${ }^{65}$ afirmam que esses níveis aumentam em certas gestações com complicações, incluindo pré-eclâmpsia e casos em que há algum tipo de dano placentário ou aneuploidia fetal.

A quantidade mensurada do DNA-FL depende de fatores biológicos como idade gestacional, patologia materna e/ou placentária. A grande vantagem da utilização desse DNA-FL em comparação com as células fetais é a rápida eliminação desse material na circulação materna em poucas horas após o nascimento, sendo sua meia vida de 16 horas, após cesariana, e de 10 a 100 horas, após o parto normal ${ }^{62}$.

\subsection{Teste de diagnóstico pré-natal não invasivo}

\subsubsection{Genotipagem $R H D$ fetal}

A determinação do genótipo RHD fetal foi almejada por muitos anos pela Medicina Fetal. Os primeiros estudos para predizer o genótipo fetal 
ocorreram em meados dos anos 90, depois da caracterização molecular do gene $R H^{17}$.

Inicialmente, a genotipagem era realizada tendo como fonte DNA proveniente de amniócitos, células trofoblásticas ou células fetais ${ }^{19}$. Esse DNA era obtido por procedimentos invasivos como amniocentese ou cordocentese, que estão associados à hemorragia feto-materna e a perdas fetais ${ }^{5}$.

Referidos procedimentos invasivos são de alto custo, de difícil realização, e requerem profissionais e centros de referência especializados ${ }^{66}$. Devido a grandes desvantagens dos procedimentos invasivos, não houve uma aplicação clínica aceitável para a realização da genotipagem $R H D$ fetal.

Todavia, a partir da descoberta inovadora de DNA-FL no plasma materno, abriram-se as possibilidades de diagnóstico pré-natal não invasivo. Tal abordagem é viável quando o feto possui sequências de ácidos nucleicos que não são encontradas na mãe. Esse material pode ser extraído de forma simples e inócua (pela coleta de sangue periférico materno).

O teste pré-natal não invasivo tem sido estabelecido como uma forma de determinar-se o sexo fetal, $R H D$ fetal, anormalidades cromossômicas como aneuploidia, hemoglobinopatias, doença Tay-Sachs, doença falciforme, fibrose cística, síndrome do $X$ frágil, distrofia muscular, além de anormalidades relacionadas à má formação como, espinha bífida e fenda palatina ${ }^{67}$.

Especificamente em relação ao teste de determinação do genótipo $R H D$ fetal, ele foi o primeiro teste com aplicabilidade clínica. É utilizado para 
auxiliar na conduta clínica a gestantes $\mathrm{RhD}$ negativo que carregam fetos RhD positivo e apresentam o risco iminente de aloimunização e subsequente DHPN.

No início do século $\mathrm{XXI}$, inúmeros pesquisadores buscaram incansavelmente a melhor metodologia para predizer o genótipo RHD fetal no plasma materno ${ }^{68}$. Os primeiros estudos utilizaram extração manual e técnica de PCR convencional ${ }^{19,69}$. Com o avanço tecnológico, novos trabalhos foram realizados, utilizando plataformas de extração automatizada e equipamentos de PCR em tempo real ${ }^{70,71}$.

Em 2004, um grupo de 50 pesquisadores europeus de 19 países se reuniram e fundaram a rede SAFE (Special Advances in Fetal and Neonatal Evaluation), com o objetivo de analisar a acurácia, o custo e a efetividade da introdução de um procedimento não invasivo para o diagnóstico de patologias que acometem o feto, entre elas, a DHPN pelo antígeno RhD ${ }^{71}$.

\subsubsection{Aspectos laboratoriais}

\subsubsection{Obtenção e processamento do plasma materno}

Para uma execução confiável do teste de genotipagem $R H D$ fetal, vários estudos têm enfatizado a relevância dos cuidados na fase préanalítica da amostra tais como: escolha do tubo, transporte, processamento, centrifugação e estoque ${ }^{25,72}$.

Inicialmente, a coleta de sangue materno é obtida de sangue periférico, utilizando tradicionalmente o tubo com ácido etilenodiamino tetra- 
acético (EDTA) com ou sem gel separador ${ }^{25}$. O volume de sangue coletado varia de 3-20 mL, porém é prudente coletar mais de $10 \mathrm{~mL}$ devido à eventual necessidade de repetição dos testes ${ }^{73}$.

Após a etapa da coleta, dois parâmetros que influenciam diretamente nos níveis do DNA-FL são o tempo e a temperatura da amostra ${ }^{74}$. Estudos apontam que é necessário um transporte rápido entre 2-6h à temperatura ambiente (TA) ou a $4^{\circ} \mathrm{C}$, para garantir que não haja hemólise de células nucleadas maternas e, consequentemente, liberação de DNA materno no plasma $25,27,75,76,77$.

Entretanto, diferentes estudos concluíram que o transporte pode exceder alguns dias. As amostras podem ser mantidas em TA ou a $4^{\circ} \mathrm{C}$ sem afetar os níveis de DNA livre, principalmente se utilizar o tubo específico, cell - free DNA BCT ${ }^{\circledR}$ (Streck, USA) ${ }^{78,79}$.

$\mathrm{Na}$ etapa de processamento das amostras envolve dois tipos de centrifugação. A primeira rotação entre $800 \mathrm{~g}$ a $3000 \mathrm{~g}$ por 10 minutos tem como objetivo separar o plasma dos eritrócitos, observando se não há contaminação da camada de leucócitos materna ${ }^{73,74,75,76,77}$. A segunda rotação entre $2400 \mathrm{~g}$ a $16000 \mathrm{~g}$ por 10 minutos tem como objetivo remover todos os resíduos de células intactas ${ }^{73,74,75,76,77}$.

$\mathrm{Na}$ etapa de estocagem, o material biológico (plasma) e armazenado entre $-20^{\circ}$ e $-30^{\circ} \mathrm{C}^{73,74,75}$. 


\subsubsection{Extração do DNA Fetal}

A extração do DNA fetal é um processo determinante para o sucesso da genotipagem fetal. A sensibilidade e a especificidade do método estão fortemente relacionados à quantidade de DNA detectado ${ }^{53}$, ademais o volume submetido na extração, é o grande diferencial para garantir a presença do DNA fetal.

O DNA fetal pode ser extraído de forma manual ou automatizada. A extração manual mais utilizada é a metodologia de coluna, cuja extração do DNA é realizada por meio de membranas de sílica ${ }^{80,81}$. A extração automatizada utiliza a metodologia baseada em partículas magnéticas recobertas por sílica, às quais o ácido nucleico se liga, sendo capturado no final do processo por hastes magnéticas ${ }^{31,73,82}$.

Os kits utilizados para a extração do DNA-FL são geralmente destinados à purificação de DNA genômico de sangue total, soro ou plasma.

Atualmente, os kits manuais mais utilizados são QIAamp DSP Virus kit, QIAamp DNA Blood Mini Kit, QiAamp Circulation Nucleic Acid kit (Qiagen, Alemanha) e o High Pure PCR Template Preparation Kit (Roche, Suíça) ${ }^{80,81,83}$. Os equipamentos automatizados mais utilizados são MagNa Pure Compact, MagNa Pure LC, Light Cyler (Roche, Suíça), QIAsymphony, MDx BioRobot e BioRobot M48 (Qiagen, Alemanha) ${ }^{83}$. 


\subsubsection{Reação em Cadeia da Polimerase em tempo real}

A PCR consiste em amplificar cópias de DNA in vitro usando os elementos básicos do processo de replicação natural. Há dois tipos de PCR: PCR convencional e PCR em tempo real ${ }^{84}$.

A PCR em tempo real é capaz de monitorar o progresso da PCR enquanto ela progride (ou seja, em tempo real). Os dados são, dessa forma, coletados ao longo da PCR, ao invés de serem apenas no final da reação. Essa possibilidade de monitorar a reação em tempo real revolucionou o processo de quantificação de fragmentos de DNA e RNA ${ }^{85}$. Assim, apresenta características relevantes como rapidez, especificidade, sensibilidade, quantificação, custo relativamente baixo e reduzido potencial de contaminação.

A PCR em tempo real básica é dividida em três fases:

1. Fase exponencial: a sequência alvo é duplicada e acumulada a cada ciclo (eficiência da reação de $100 \%$ ). A amplificação exponencial ocorre porque, nessa fase, há grande quantidade de reagentes frescos e disponíveis. Nos ciclos iniciais da PCR, há uma pequena emissão de fluorescência que é conhecida como linha de base.

2. Fase linear: há uma alta variabilidade, pois com o progresso da reação, alguns reagentes são consumidos como resultado da amplificação. Nessa fase, as reações de amplificação começam a diminuir e o produto da PCR não é mais duplicado a cada ciclo. A detecção de fluorescência acima da linha base indica a amplificação da região alvo. 
3. Fase platô: a reação é finalizada e não há mais formação do produto. Contudo, cada tubo ou reação irá atingir um limite máximo em diferentes pontos, devido a diferentes reações cinéticas para cada amostra, de acordo com a quantidade inicial de DNA alvo ${ }^{84,85}$.

No teste de genotipagem $R H D$ fetal o método mais utilizado é o sistema TaqMan ${ }^{\circledR}$ (Applied Biosystems, USA), também conhecido como, ensaio para nuclease 5' fluorescente. Esse sistema utiliza uma sonda fluorescente, para possibilitar a detecção de um produto específico da PCR, conforme esse acumula durante os ciclos da reação ${ }^{85}$.

O sistema $\operatorname{TaqMan}^{\circledR}$, utiliza quatro etapas de processo: na primeira etapa, uma sonda (oligonucleotídeo) é construída contendo um fluoróforo reporter fluorescente na extremidade 5' e um fluoróforo quencher (silenciador) na extremidade 3'. Enquanto a sonda está intacta a proximidade do quencher reduz bastante à fluorescência emitida pelo reporter, através da transferência de energia por ressonância de fluorescência (FRET) ${ }^{85}$.

Na segunda etapa, se a sequência alvo estiver presente, a sonda se anela logo após um dos primers, sendo clivada através da atividade da nuclease 5' da Taq DNA polimerase, enquanto o primer e estendido.

$\mathrm{Na}$ terceira etapa, ocorre a clivagem da sonda, onde separa o reporter do quencher, aumentando o sinal do reporter.

$\mathrm{Na}$ quarta etapa, o reporter é clivado da sonda a cada ciclo, resultando em um aumento na intensidade de fluorescência, que é proporcional à quantidade de amplicon produzido ${ }^{85}$. 
Na PCR em tempo real, a emissão da fluorescência é captada pelo equipamento a cada ciclo produzindo um gráfico de amplificação. 0 resultado final é apresentado em um gráfico ${ }^{84,85}$.

O equipamento calcula dois valores: o threshold (limiar) e o Cycle threshold (Ct) (Ciclo limiar). O limiar é o nível de detecção em que a reação atinge uma intensidade de fluorescência acima da fluorescência de fundo. $\mathrm{O}$ ciclo da PCR em que a amostra atinge esse nível é chamado de $\mathrm{Ct}^{85}$ (Figura 6).

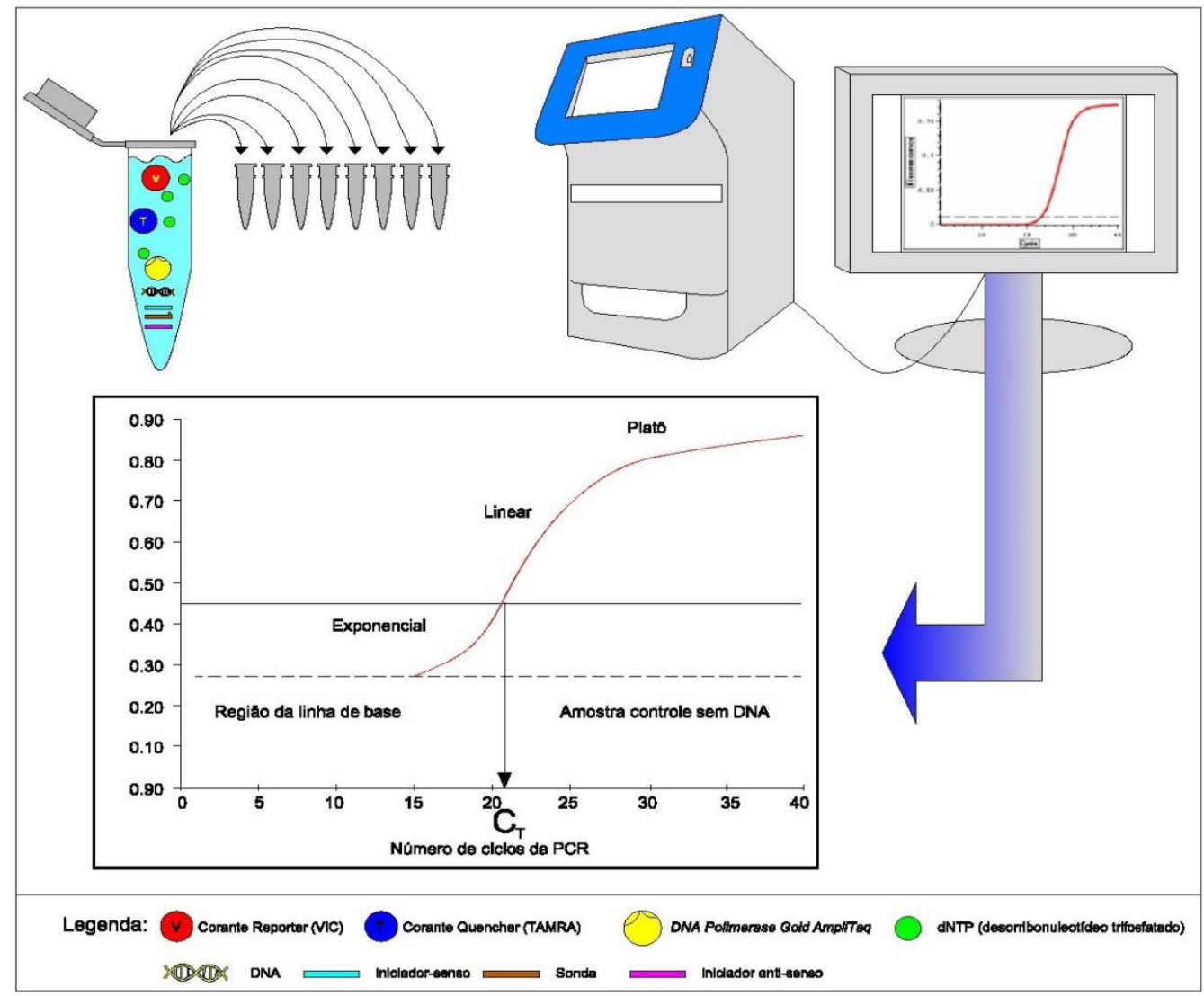

Figura 6 - Representação esquemática da PCR em tempo real

A reação é preparado em um microtubo $1 \mathrm{~mL}$, e adicionado os seguintes componentes: TaqMan Universal Master Mix II (AmpliTaq Gold $₫$ DNA polimerase, Ultra Pure, dNTPs, ROX ${ }^{\mathrm{TM}}$ Passive referência, Uracil-N glicosilase e componentes do tampão otimizados, representado pelo líquido azul); Primers senso e anti-senso; Sonda; DNA. A reação e inserida no equipamento de PCR em tempo real, e conectada a um computador. A emissão de fluorescência é captada pelo equipamento a cada ciclo produzindo um gráfico de amplificação. 


\subsubsection{4 Éxons alvos no teste de genotipagem $R H D$ fetal}

A detecção molecular do gene $R H D$ deve alcançar alta especificidade e requer um ensaio capaz de distinguir entre o gene $R H D$ e o RHCE.

Os primers (ou pelo menos um deles) deve amplificar somente a sequência alvo do gene $R H D$. As diferenças de nucleotídeos entre o gene RHD e RHCE devem ser exploradas no desenho dos primers e sondas para garantir a distinção entre o alelo $D$ e os alelos $C / c$ e E/e $24,86,87$.

Finning et al. $(2008)^{77}$ recomendam a inclusão do éxon 4 ou 5 , combinado com um éxon alternativo 7 ou 10. Essa combinação da análise de duas regiões do gene $R H D$ possibilita uma melhor detecção de algumas variantes genéticas do gene $R H D$, possibilitando uma interpretação mais acurada.

O grupo SAFE recomenda a coamplificação de pequenos fragmentos do éxon 5 e éxon 7 na rotina da genotipagem $R H D$ fetal ${ }^{71}$.

O ensaio do éxon 5 é baseado no estudo de Finning et al. (2002) ${ }^{27}$ que amplifica apenas o gene $R H D$, mas negativo nas principais variantes gênicas (pseudogene $R H D \Psi$ e gene híbrido $R H D-C E-D^{s}$ ). O ensaio do éxon 7 é baseado no estudo de Fass et al. (1998) ${ }^{88}$, que detecta o RHD $\psi$, entretanto não detecta o gene híbrido.

\subsubsection{Controles do teste de genotipagem RHD fetal}

A inclusão de controles é importante para assegurar a presença do DNA extraído e garantir um resultado confiável da PCR ${ }^{53}$. Atualmente é utilizado o controle de amplificação de DNA total que garante excelência na 
extração e na PCR em tempo real. Os mais utilizados são o gene CCR5 $76,77,89$, O GAPDH (gliceraldeído-3-fosfato desidrogenase) ${ }^{65,75,}, \beta$-globina ${ }^{19,80}$ e $\beta$-actina ${ }^{73}$.

Muitos estudos utilizam como controle de amplificação de DNA fetal as regiões do cromossomo $Y$, que são as mais indicadas. As sequências mais utilizadas são $S R Y, D S Y 14$ ou $D A Z^{65,75,89,90}$.

A presença de amplificação para a sequência do $Y$ garante DNA fetal na amostra, indicando feto masculino, além de confirmar excelência na extração e na PCR em tempo real. Quando a ausência de amplificação indica que não há sequência de ácidos nucleicos para o cromossomo $\mathrm{Y}$, indicando feto feminino. Entretanto, pode haver ausência de amplificação, o que pode ser atribuído a possíveis falhas de extração e/ou PCR.

Chan e colaboradores (2006) ${ }^{91}$ demonstraram que o promotor do gene RASSF1A é hipermetilado na placenta e em células sanguíneas maternas, sendo um marcador universal de DNA-FL. Entretanto, é raramente usado na rotina diária, devido às etapas da análise serem trabalhosas ${ }^{24}$.

Além dos controles de amplificação, são necessários controles para garantir o resultado da PCR. Normalmente, são utilizados controles previamente conhecidos de DNA genômico de indivíduos RhD positivo e RhD negativo ${ }^{77}$, DNA plasmático de gestantes com feto $R H D$ positivo ou de plasma de indivíduos $\mathrm{RhD}$ positivo. ${ }^{77,92}$ 


\subsection{Acurácia do teste de genotipagem RHD fetal}

Acurácia é a proporção total de resultados corretos, ou seja, o total de verdadeiro positivo e o verdadeiro negativo em relação à amostra estudada. No teste de genotipagem $R H D$ fetal, a acurácia é determinada pela comparação entre genótipo $R H D$ fetal preditivo e o resultado sorológico da análise de sangue do cordão umbilical ou sangue periférico do recémnascido ${ }^{24,93}$.

Desde a descoberta do DNA-FL, a acurácia do teste de genotipagem RHD fetal é investigada e tem aumentado gradualmente de $90 \%$ para aproximadamente, $100 \%$ no período de 1998-2015, portanto, assegurando um resultado altamente confiável ${ }^{24}$.

Inúmeros estudos validaram a acurácia do teste nos três trimestres gestacionais e utilizaram diferentes regiões do gene $R H D$. As sequências mais utilizadas foram pequenos fragmentos dos éxons 4, 5, 7 e 10. (Tabela $1)$. 
Tabela 1 - Acurácia das principais publicações realizadas no período de 1998-2014

\begin{tabular}{|c|c|c|c|c|c|}
\hline Autor & Ano & $\mathbf{N}$ & IG & Éxon & Acurácia \\
\hline Lo et al. ${ }^{22}$ & 1998 & 57 & $7-41$ & 10 & 96,0 \\
\hline Faas et al. ${ }^{88}$ & 1998 & 31 & $16-17$ & 7 & 100 \\
\hline Zhang et al. ${ }^{94}$ & 2000 & 58 & $10-21$ & 7 & 98,0 \\
\hline Legler et al. ${ }^{95}$ & 2002 & 27 & $11-38$ & 4,7 & 96,0 \\
\hline Finning et al. ${ }^{27}$ & 2002 & 137 & $8-42$ & $4,5,6,10$ & 100 \\
\hline Costa et al. ${ }^{96}$ & 2002 & 102 & $8-14$ & 10 & 100 \\
\hline Turner et al ${ }^{97}$. & 2003 & 31 & $<20$ & 10 & 90,0 \\
\hline Randen et al. ${ }^{98}$ & 2003 & 114 & $6-38$ & 7 & 92,0 \\
\hline Rijnders et al. ${ }^{99}$ & 2004 & 72 & $11-19$ & 7 & 99,0 \\
\hline Finning et al. ${ }^{75}$ & 2004 & 283 & $8-42$ & $4,5,10$ & 100 \\
\hline Gautier et al. $^{76}$ & 2005 & 285 & $8-35$ & 10 & 100 \\
\hline Hromanikova et al. ${ }^{100}$ & 2005 & 24 & $11-38$ & 7,10 & 100 \\
\hline Machado et al ${ }^{19}$. & 2006 & 81 & $4-41$ & 10 , intron 4 & 97,3 \\
\hline Van der Schoot et al ${ }^{101}$ & 2006 & 1257 & 30 & 7 & 99,6 \\
\hline Rouillac-Le Sciellar et al ${ }^{102}$ & 2007 & 300 & $10-34$ & 7,10 & 99,3 \\
\hline Muller et al. ${ }^{90}$ & 2008 & 1113 & $6-32$ & 5,7 & 99,8 \\
\hline Minon et al. ${ }^{103}$ & 2008 & 563 & $10-38$ & $4,5,10$ & 99,8 \\
\hline Finning et al. ${ }^{77}$ & 2008 & 1869 & $8-28$ & 5,7 & 99,7 \\
\hline Chinen et al. ${ }^{104}$ & 2010 & 102 & $07-36$ & 7,10 & 98,0 \\
\hline Amaral et al. ${ }^{105}$ & 2011 & 88 & $11-39$ & $4,5,10$ & 100 \\
\hline De Haas et al . ${ }^{106}$ & 2012 & 6941 & 27 & 5,7 & $>99,6$ \\
\hline \multirow[t]{5}{*}{ Daniels et al. ${ }^{107}$} & 2012 & 865 & $<11$ & 5,7 & 96,2 \\
\hline & & 956 & $11-13$ & 5,7 & 99,8 \\
\hline & & 542 & $14-17$ & 5,7 & 99,5 \\
\hline & & 888 & $18-23$ & 5,7 & 99,8 \\
\hline & & 1625 & $>24$ & 5,7 & 100 \\
\hline Clausen et al. ${ }^{31}$ & 2012 & 2312 & 25 & 5,$7 ; 7,10 ; 5,10$ & 99,9 \\
\hline \multirow[t]{4}{*}{ Wikman et al. ${ }^{34}$} & 2012 & 3652 & $3-7$ & 4 & 97,6 \\
\hline & & & $8-9$ & 4 & 98,9 \\
\hline & & & $10-21$ & 4 & 99,3 \\
\hline & & & $22-40$ & 4 & 100 \\
\hline Dovč-Drnovšek et al. ${ }^{108}$ & 2013 & 153 & $7-38$ & $5,7,10$, intron 4 & 100 \\
\hline Grande et al. ${ }^{109}$ & 2013 & 284 & $24-26$ & 5,7 & 99,6 \\
\hline Schimidt et al. ${ }^{110}$ & 2014 & 55 & $12-29$ & 5,7 & 100 \\
\hline
\end{tabular}

Legenda: N: número de casos; IG: Idade gestacional em semanas; Éxon: Gene RHD; Acurácia: Porcentagem (\%) 
Daniels e colaboradores (2012) ${ }^{107}$ no Reino Unido realizaram o estudo em larga escala, com 4876 gestantes, em diferentes IGs e obtiveram acurácia de $100 \%$ em gestantes acima de 24 semanas. Amostras coletas com menos de 11 semanas, foram as que apresentaram uma menor acurácia, de 96,2\% com 16 casos de falso-negativo.

Outro estudo em larga escala foi realizado por Wikman e colaboradores $(2012)^{34}$, que obtiveram $100 \%$ de acurácia com amostras entre 22-40 semanas. As amostras coletadas precocemente, entre 3 a 7 semanas, obtiveram $97,6 \%$ de acurácia e houve 55 falso-negativos. As amostras com 8 e 9 semanas obtiveram 98,9\% e 23 falso-negativos. As amostras com 10-21 semanas obtiveram 99,3\% com 14 falso-negativos.

Após a comprovação da sensibilidade e especificidade do teste, alguns países já iniciaram suas implantações em programas de pré-natal.

O teste foi introduzido nacionalmente no programa de pré-natal na Dinamarca, em 2010, Holanda, em 2011 e na Finlândia, em 2014. Similarmente, em âmbito regional, foi implantado em centros de referência na Suíça, França e Bélgica, em 2009, e na Inglaterra, em $2013^{24}$. 


\subsection{Delineamento do estudo}

Trata-se de estudo do tipo prospectivo.

A avaliação deste estudo baseou-se na comparação independente e cega do teste semiautomatizado para a determinação do genótipo $R H D$ fetal no plasma materno com o teste padrão-ouro, fenotipagem RhD.

\section{2 Ética}

O projeto de pesquisa foi aprovado pelo Comitê de Ética do Departamento de Obstetrícia e Ginecologia e pela Comissão de Ética para Análise de Projetos de Pesquisa (CAPPesq) do Hospital das Clínicas da Faculdade de Medicina da Universidade de São Paulo (HC-FMUSP) em 19/10/2011 (número do parecer: 0575/11) (Anexo 1). Foi aplicado o Termo de Consentimento Livre e Esclarecido (TCLE) (Anexo 2).

\subsection{Cálculo amostral}

O cálculo amostral foi baseado na frequência de indivíduos $\mathrm{RhD}$ negativo na população brasileira, que é cerca de $10 \%{ }^{10}$. Para o cálculo do tamanho da amostra, foi utilizada a fórmula abaixo para hipótese nula verdadeira, ou seja, que a acurácia aferida na pesquisa seja real. Foi considerado: um poder de $90 \%$, um nível de significância de $5 \%$ e uma diferença de proporções de $10 \%$ entre os testes. 
Utiliza-se a fórmula abaixo para hipótese nula verdadeira:

$$
n=\frac{2 p(100-p) \times 10,5}{d 2}
$$

$p=$ acurácia do teste novo $=90 \%$

$d$ = diferença máxima entre o padrão-ouro e o novo teste $=10 \%$

poder $=90 \%($ beta $=0,10)$

nível significância $=5$ (alfa $=0,05$ e intervalo de confiança de $95 \%)$

teste monocaudal

10,5 = constante (função de alfa=0,05 e beta=0,10)

$$
\mathrm{n}=179
$$

\subsection{Amostras}

Foram coletadas amostras de sangue periférico de gestantes RhD negativo atendidas na Clínica Obstétrica do HC-FMUSP, no período de Maio/2012 a Junho/2014, conforme os critérios de inclusão e exclusão.

\subsubsection{Critérios de inclusão}

- Gestante RhD negativo

- Idade gestacional entre 8-28 semanas

- Sem histórico de transplante de órgãos ou medula óssea. 


\subsubsection{Critérios de exclusão}

- Impossibilidade de determinação do fenótipo RhD do recém-nascido.

\subsubsection{Recrutamento e identificação das gestantes}

O recrutamento das gestantes foi realizado no ambulatório da Clínica Obstétrica do HC-FMUSP e dividido em três etapas:

1) Verificado, a fenotipagem $R h D$ na carteirinha do pré-natal.

2) Confirmado, pelo Sistema Informatizado de Laudo da Obstetrícia e Ginecologia (SILOG) a viabilidade da gestação e a idade gestacional.

3) Conferido, a Tipagem Sanguínea (TS) no Sistema de Informação e Gestão Hospitalar (SIGH), exame realizado pelo Laboratório de Imuno-hematologia Clínica, Serviço de Hematologia do HCFMUSP.

Após as três etapas do recrutamento, as mulheres que se enquadravam nos critérios foram convidadas a participar do estudo.

A maioria das gestantes foi recrutada no ambulatório do grupo de aloimunização materno-fetal da Clínica Obstétrica do HC-FMUSP, porém gestantes não aloimunizadas de outros setores da clínica também foram incluídas. Todas as participantes foram orientadas sobre o propósito do estudo. 
Foi preenchido um questionário (Anexo 3) e após a assinatura do TCLE, as gestantes foram direcionadas a uma sala de coleta no Ambulatório da Clínica Obstétrica.

\subsubsection{Coleta}

De cada gestante foi coletado entre $10-12 \mathrm{~mL}$ de sangue de vaso periférico com agulha (BD Vacutainer $®$, EUA), e distribuído em dois tubos com conservante do tipo ácido etilenodiamino tetra acético (EDTA) (BD Vacutainer®, EUA).

Um tubo com $8,5 \mathrm{~mL}$ com gel separador foi utilizado para a obtenção de plasma e subsequente DNA plasmático. O outro tubo foi utilizado para a realização da fenotipagem $\mathrm{RhD}$.

A fenotipagem foi realizada visando descartar mulheres mal informadas de seu fenótipo, erros laboratoriais, ou ainda, identificar eventuais $\mathrm{RhD}$ fracos e $\mathrm{RhD}$ parciais, que possam apresentar resultados incoerentes ao final da análise.

Após a coleta, os tubos e o TCLE correspondente a cada gestante foram identificados com uma etiqueta adesiva contendo nome, data e horário de coleta. 


\subsubsection{Processamento e Armazenamento}

Posteriormente à coleta, em no máximo 2 horas, o material biológico foi encaminhado para o laboratório de Biologia Molecular da Fundação Pró-Sangue - Hemocentro de São Paulo, Brasil.

Os dois tubos foram processados a $2200 \mathrm{~g}$ por 10 minutos na centrífuga 5702 (Eppendorf, Alemanha). A primeira centrifugação tem por objetivo separar o plasma, evitando o excesso de DNA materno decorrente do processo de lise celular.

O tubo com gel separador foi armazenado em freezer a $-70{ }^{\circ} \mathrm{C}$ (Thermo Scientific Revco®, EUA), o outro tubo foi armazenado em geladeira a $2-8^{\circ} \mathrm{C}$ (Thermo Scientific Revco $\AA$, EUA).

Para a preparação da análise molecular, o tubo com gel separador foi descongelado, e o plasma foi colocado em microtubo 1,5 mL. Nesse tubo foi realizada uma nova centrifugação a $16.000 \mathrm{~g}$ por 10 minutos a $4^{\circ} \mathrm{C}$ na centrifuga 5417R (Eppendorf, Alemanha). A segunda centrifugação tem por objetivo remover os resíduos de células maternas ou proteínas que não o foram no primeiro processo ${ }^{111}$.

\subsubsection{Fenotipagem RhD materna}

A fenotipagem RhD materna foi determinada pelo teste de hemaglutinação. Foi utilizada a metodologia em gel teste, cartão IDDiaClon ABO/D + Prova Reversa (Diamed ${ }^{\circledR}$ S.A., Brasil). 
Para a execução do teste, foi preparada uma suspensão de hemácias a $5 \%$, na qual foi adicionado $500 \mu \mathrm{L}$ de solução de baixa força iônica (LISS modificada) ID-Diluent 2 (Diamed $^{\circledR}$ S.A., Brasil) e $25 \mu \mathrm{L}$ do concentrado de hemácias.

No microtubo do cartão que contém anti-A, anti-B, anti-D e controle, foi adicionado $10 \mu \mathrm{L}$ da suspensão a $5 \%$. Nos dois microtubos com gel neutro foram adicionados $50 \mu \mathrm{L}$ de hemácias comerciais IDDiacell A1 e ID-Diacell B (Diamed ${ }^{\circledR}$ S.A., Brasil), e depois, adicionou-se 50 $\mu \mathrm{L}$ do plasma da gestante. O cartão foi centrifugado a $1000 \mathrm{~g}$ por 10 minutos na ID-Centrífuga $\left(\right.$ Diamed $^{\circledR}$, Suíça). Após o resultado foi interpretado e anotado.

Para a confirmação do fenótipo $\mathrm{RhD}$ negativo, foi realizada a pesquisa de $\mathrm{RhD}$ fraco em tubo foi pela técnica indireta de antiglobulina humana. Foi utilizado o soro Duoclone Monoclonal (IgG + $\lg M$ - clones MS-26 + RUM-1) e Controle Anti-D Monoclonal (Lorne Laboratories LTD., Reino Unido).

Para a execução do teste, foi preparada uma suspensão de hemácias a $5 \%$ na qual foi adicionado $1000 \mu \mathrm{L}$ de solução salina - $\mathrm{NaCl}$ 0,9\% (Baxter Hospitalar LTDA, Brasil), e $50 \mu \mathrm{L}$ do concentrado de hemácias.

Foram identificados dois tubos de vidro, com a descrição Anti-D e o outro controle RhD. No tubo com Anti-D foi adicionado $50 \mu \mathrm{L}$ do soro Duoclone Monoclonal, e no tubo controle RhD foi adicionado $50 \mu \mathrm{L}$ do 
soro Controle Anti-D Monoclonal. Em seguida, foi adicionado, em cada tubo, $50 \mu \mathrm{L}$ da suspensão de hemácias.

Os tubos foram centrifugados a $1000 \mathrm{~g}$ por 15 segundos, na centrifuga DiaCent-12 $\left(\right.$ Diamed $^{\circledR}$, Suíça). Foi realizada a leitura, se o resultado apresentou-se negativo em ambos os tubos, eles foram incubados a $37^{\circ} \mathrm{C}$ por 15 minutos em banho Maria (FANEM ${ }^{\circledR}$, Brasil). Após a incubação, os tubos foram novamente centrifugados na mesma rotação e tempo como já descrito acima. Se os resultados permanecessem negativos, os tubos eram lavados três vezes com solução salina no equipamento DiaCent-CW (Diamed ${ }^{\circledR}$, Suíça). Ao final da lavagem, adicionou-se em cada tubo $100 \mu \mathrm{L}$ de soro de Coombs (Antiglobulina humana) (Fresenius HemoCare Brasil, LTDA, Brasil)

A interpretação do resultado final foi a seguinte: presença de aglutinação no Anti-D e negativo, no controle RhD, foi considerada RhD positivo. Ausência de aglutinação em ambos os tubos foi considerada RhD negativo.

\subsection{Definição da metodologia}

\subsubsection{Método de extração}

A extração do DNA foi realizada no equipamento automatizado MagNa Pure Compact (Roche, Suíça) com o kit Large Volume (LV) (Roche, Suíça). 


\subsubsection{Validação do equipamento}

O equipamento e o kit LV foram avaliados quanto ao rendimento, volume de amostra, volume de eluição, tempo de procedimento, contaminação interamostra, necessidades de intervenção humana, estabilidade dos reagentes, reprodutibilidade e praticidade.

O MagNA Pure Compact é um equipamento robótico que extrai DNA e RNA a partir de uma ampla variedade de materiais biológicos como: células de mamíferos, sangue total ou plasma, células cultivadas e tecidos ${ }^{112}$. É possível extrair um volume entre $100-1000 \mu \mathrm{L}$ e eluir os ácidos nucleicos entre 50-200 $\mu \mathrm{L}$. O equipamento extrai oito amostras em 40 minutos. Além disso, possui luz ultravioleta que garante a esterilização interna após o uso ${ }^{112}$.

O kit LV é baseado na ligação dos ácidos nucleicos a Magnectic Glass Particles (MGPs) e extrai até 1000 uL de plasma ${ }^{112}$.

O princípio do isolamento de ácido nucleico realizado pelo equipamento automatizado MagNA Pure Compact com o Kit LV está descrito na figura 7 . 


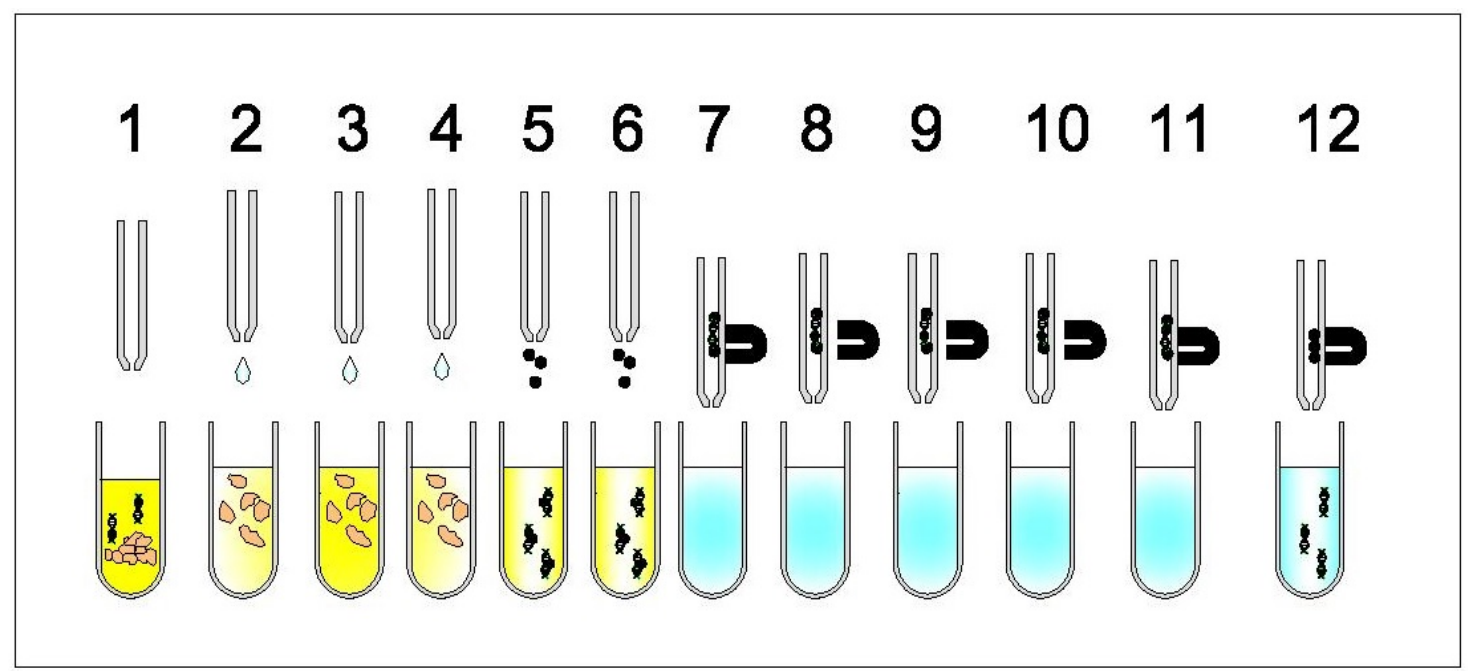

Figura 7 - Princípio da extração realizada com o kit LV no equipamento automatizado MagNA Pure Compact

A extração é dividida em quatro etapas: purificação, ligação das Magnectic Glass Particles (MGPs), lavagem e eluição. No tubo 1, temos a amostra plasmática, representado pela cor amarela, que contém o DNA livre e restos de células maternas. O cartucho de extração contém onze tubos. Nos tubos 2, 3 e 4, estão à proteína $\mathrm{K}$ e o tampão de lise, nesses tubos ocorre à lise celular, etapa de purificação. Nos tubos 5 e 6, estão as MGPs, nesses tubos ocorre a ligação das MGPs ao DNA, etapa de ligação. No tubo 7, está o isopropanol, representado pela cor azul, nesse tubo ocorre a separação magnética das MGPs com o DNA. Nos tubos $8,9,10$, estão os tampões de lavagem I e II. No tubo 11, está o tampão de lavagem III, nesses tubos representados pela cor azul, ocorre à remoção de restos celulares, etapa de lavagem. No tubo 12, está o tampão de eluição, nesse tubo ocorre à separação das MGPs do DNA, etapa de eluição.

\subsubsection{PCR em tempo real para o gene RHD}

O método de PCR em tempo real e as regiões alvo deste estudo foram semelhantes aos descritos pelo consórcio europeu SAFE ${ }^{83}$. Esse método realiza a coamplificação de pequenos fragmentos dos éxons 5 e 7 do gene $R H D$.

Os primers e a sonda do éxon 5 amplificam apenas o gene $R H D$, não apresentando amplificação para o pseudogene $R H D \Psi$ e gene híbrido 
$R H D-C E-D^{s}$. Os primers e a sonda do éxon 7 são específicos para o gene $R H D$, porém a variante pseudogene $R H D \Psi$ é detectável e, no gene híbrido, não o é Os primers e a sonda foram obtidos da empresa Applied Biosystems ${ }^{\circledR}$, USA (Tabelas 2 e 3).

Tabela 2 - Descrição dos primers e sondas do gene RHD, éxons 5 e 7

\begin{tabular}{|c|c|c|c|c|}
\hline $\begin{array}{c}\text { Primers e } \\
\text { sondas }\end{array}$ & Sequência (5'-3') & $\begin{array}{c}\text { reporter } \\
5^{\prime}\end{array}$ & $\begin{array}{c}\text { quencher } \\
\text { 3' }^{\prime}\end{array}$ & Fragmentc \\
\hline \multicolumn{5}{|l|}{ Éxon 5 - RHD } \\
\hline EX5F ${ }^{27}$ & CGCCCTCTTCTTGTGGATG & & & $82 \mathrm{pb}$ \\
\hline EX5R ${ }^{27}$ & GAACACGGCATTCTTCCTTTC & & & \\
\hline$R H D$ ex5T ${ }^{27}$ & TCTGGCCAAGTTTCAACTCTGCTCTGCT & VIC & TAMRA & \\
\hline \multicolumn{5}{|l|}{ Éxon 7 - RHD } \\
\hline$R H D 940 S^{88}$ & GGGTGTTGTAACCGAGTGCTG & & & $125 \mathrm{pb}$ \\
\hline RHD $1064 \mathrm{R}^{88}$ & CCGGCTCCGACGGTATC & & & \\
\hline$R H D 968 T^{88}$ & CCCACAGCTCCATCATGGGCTACAA & FAM & TAMRA & \\
\hline
\end{tabular}

Tabela 3 - Resultados esperados para os éxons 5 e 7 com variantes silenciosas do gene $R H D$

\begin{tabular}{lllll}
\hline \multicolumn{4}{c}{ Genótipo } & \\
& $R H D \Psi$ & $R h D-C E-D^{s}$ & $R H D-$ & $R H D+$ \\
\hline Região Alvo & & & & \\
Éxon 5 & NEG & NEG & NEG & POS \\
Éxon 7 & POS & NEG & NEG & POS \\
\hline
\end{tabular}


O protocolo duplex para os éxons 5 e 7 estão descritos no anexo 4 .

Para a execução dos ensaios, foi utilizado o equipamento de PCR em Tempo Real StepOnePlus ${ }^{\mathrm{TM}}$ (Applied Biosystems ${ }^{\circledR}$, USA).

\subsubsection{Controle de qualidade interno}

Para garantir a confiabilidade do teste avaliado neste estudo, foi empregado como controle de qualidade interno para o DNA total a amplificação do gene do receptor celular de citocina 5 (CCR5) (Tabela 4).

Tabela 4 - Descrição dos pares de primers e sonda do CCR5

\begin{tabular}{|c|c|c|c|c|}
\hline $\begin{array}{c}\text { Primers e } \\
\text { sondas }\end{array}$ & Sequência (5'-3') & $\begin{array}{c}\text { reporter } \\
5^{\prime}\end{array}$ & $\begin{array}{c}\text { quencher } \\
3^{\prime}\end{array}$ & Fragmento \\
\hline \multicolumn{5}{|l|}{ CCR5 } \\
\hline CCR5_Fwd ${ }^{77}$ & TACCTGCTCAACCTGGCCAT & & & $91 \mathrm{pb}$ \\
\hline CCR5_Rev ${ }^{77}$ & TTCCAAAGTCCCACTGGGC & & & \\
\hline CCR5 Probe ${ }^{77}$ & TTTCСTTCTTACTGTCCССTTCTGGGCTC & FAM & BHQ-1 & \\
\hline
\end{tabular}

O ensaio do CCR5 foi realizado em todas as amostras maternas e testado em duas réplicas (duplicata). A reação foi executada em tubo separado da reação do $R H D$ (éxon 5 e 7), porém na mesma corrida da PCR em tempo real. O protocolo do ensaio está descrito no anexo 4.

A interpretação do resultado foi baseada nos valores de Cts $(\geq 32$ ou s38). A amostra que apresentou valores abaixo ou acima dos preestabelecidos foi considerada inválida, pois pode indicar má 
conservação, proveniente de excesso de DNA materno no plasma, quando o Ct foi menor que 32, ou degradação geral do DNA plasmático ou uma falha na etapa de extração quando $>38$.

Como controle interno da PCR em tempo real foi utilizada ao menos uma amostra previamente caracterizada como $R H D$ positivo e outra amostra RHD negativo (ambas de DNA plasmático de gestantes RhD negativo) e água.

A interpretação do resultado foi classificada da seguinte maneira:

- Amostra RHD+: ausência de amplificação do éxons 5 e 7 invalida a extração e a PCR.

- Amostra RHD-: presença de amplificação do éxons 5 e 7 invalida a extração e a PCR.

- Água: presença de amplificação do éxons 5 e/ou 7 invalida a PCR mas não a extração.

\subsection{Desenho do estudo}

Para a obtenção do DNA fetal, em cada amostra materna, foi realizada a extração em simplicata com o kit LV (1mL de plasma) no equipamento automatizado MagNA Pure Compact. O DNA extraído foi submetido à reação duplex (éxon 5 e 7) e CCR5 na PCR em tempo real StepOnePlus ${ }^{\mathrm{TM}}$.

Em cada amostra, foram realizadas duas ou três réplicas para cada éxon (duplicata ou triplicata), visando diminuir os erros de interpretação e 
execução. Dessa forma, ao final do processo, cada amplificação com Ct $<43$ foi equivalente a 1 ponto (escore), assim obtivemos 4 ou 6 resultados.

Os casos que apresentaram amplificação da PCR, nos éxons 5,7 e CCR5, foram considerados positivos.

Os casos que apresentaram ausência de amplificação na PCR, nos éxons 5 e 7, e amplificação do CCR5, foram considerados negativos.

Os casos que apresentaram amplificação de somente um dos éxons 5 ou 7, e amplificação somente do CCR5, foram considerados inconclusivos, indicando que mãe, feto ou ambos possuem uma variante $R H D$. O resultado final foi interpretado baseado nos valores de Cts juntamente com a metodologia de escores. (Tabela 5).

Tabela 5 - Metodologia do teste de genotipagem RHD fetal, baseado em valores de cts e escores

\begin{tabular}{lccccc}
\hline Resultados & $\begin{array}{c}\text { Valor de } \\
\text { Ct éxon } \\
\text { 5 e 7 }\end{array}$ & $\begin{array}{c}\text { Valor de } \\
\text { Ct CCR5 }\end{array}$ & $\begin{array}{c}\text { Escore } \\
\text { 3 Réplicas }\end{array}$ & $\begin{array}{c}\text { Escore } \\
\text { 2 Réplicas }\end{array}$ & Conclusão \\
\hline Positivo & $\leq 43$ & $\leq 38$ & $4 ; 5$ ou 6 & 3 ou 4 & Feto RHD+ \\
Negativo & $\mathrm{ND}$ & $\leq 38$ & 0 ou 1 & 0 ou 1 & Feto $R H D-$ \\
Inconclusivo & $\leq 43$ & $\leq 38$ & 2 e 3 & 2 & Inconclusivo \\
\hline
\end{tabular}

ND: Não Determinado

Os possíveis resultados obtidos na PCR em tempo real para a determinação do genótipo $R H D$ fetal estão apresentados nas figuras 8,9 e 10. 


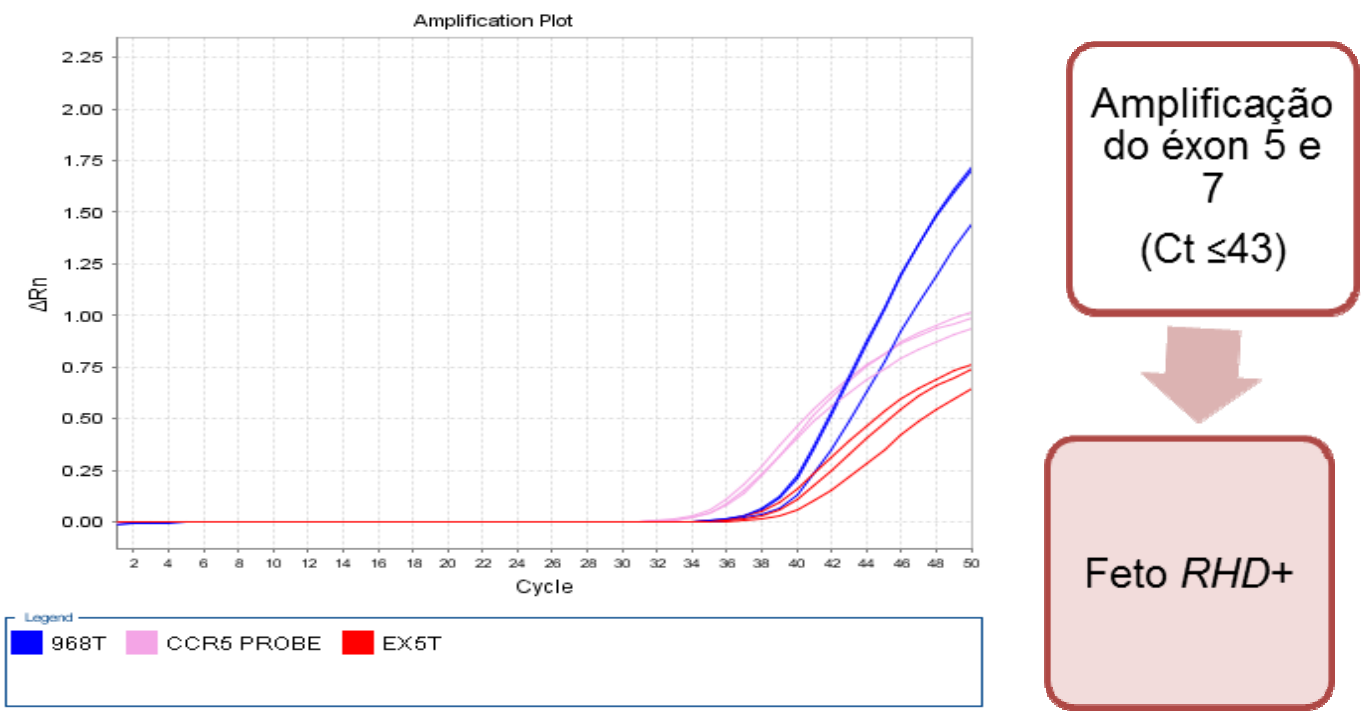

Figura 8 - Exemplo de resultado apresentado na PCR em tempo real para feto RHD+. Amplificação das três regiões alvos.

Em azul, curva de amplificação do éxon 7; em vermelho, o éxon 5 e, em rosa, o CCR5.

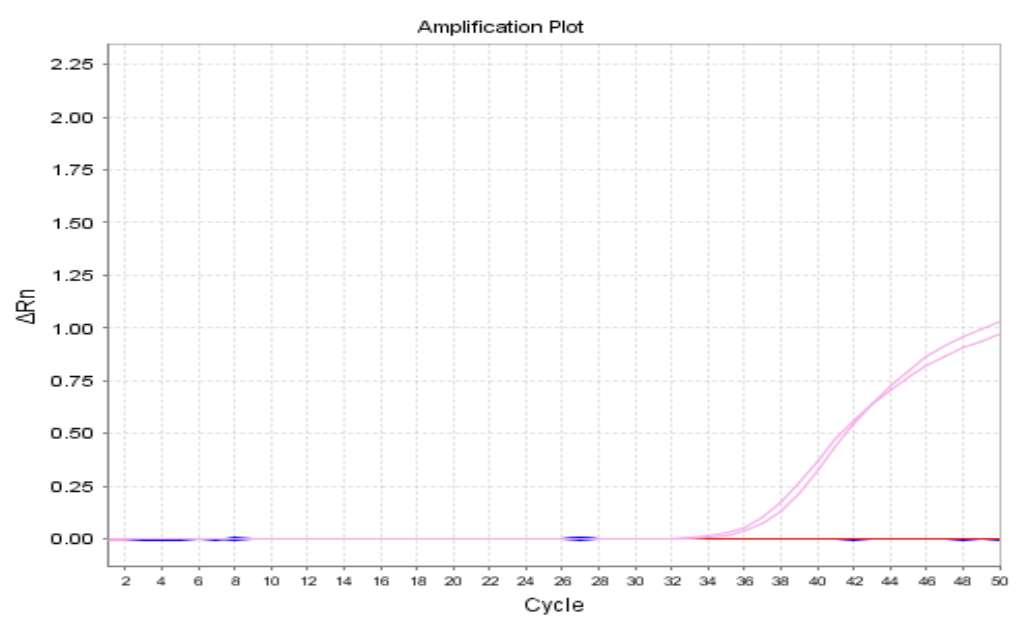

Ausência de amplificação do éxon 5 e 7

968T CCR5 PROBE $\square$ EX5T

Figura 9 - Exemplo de resultado apresentado na PCR em tempo real para feto $R H D$ -

Em azul, o éxon 7; em vermelho, o éxon 5 e, em rosa, curva de amplificação do CCR5. Ausência de amplificação dos éxons 5 e 7. 

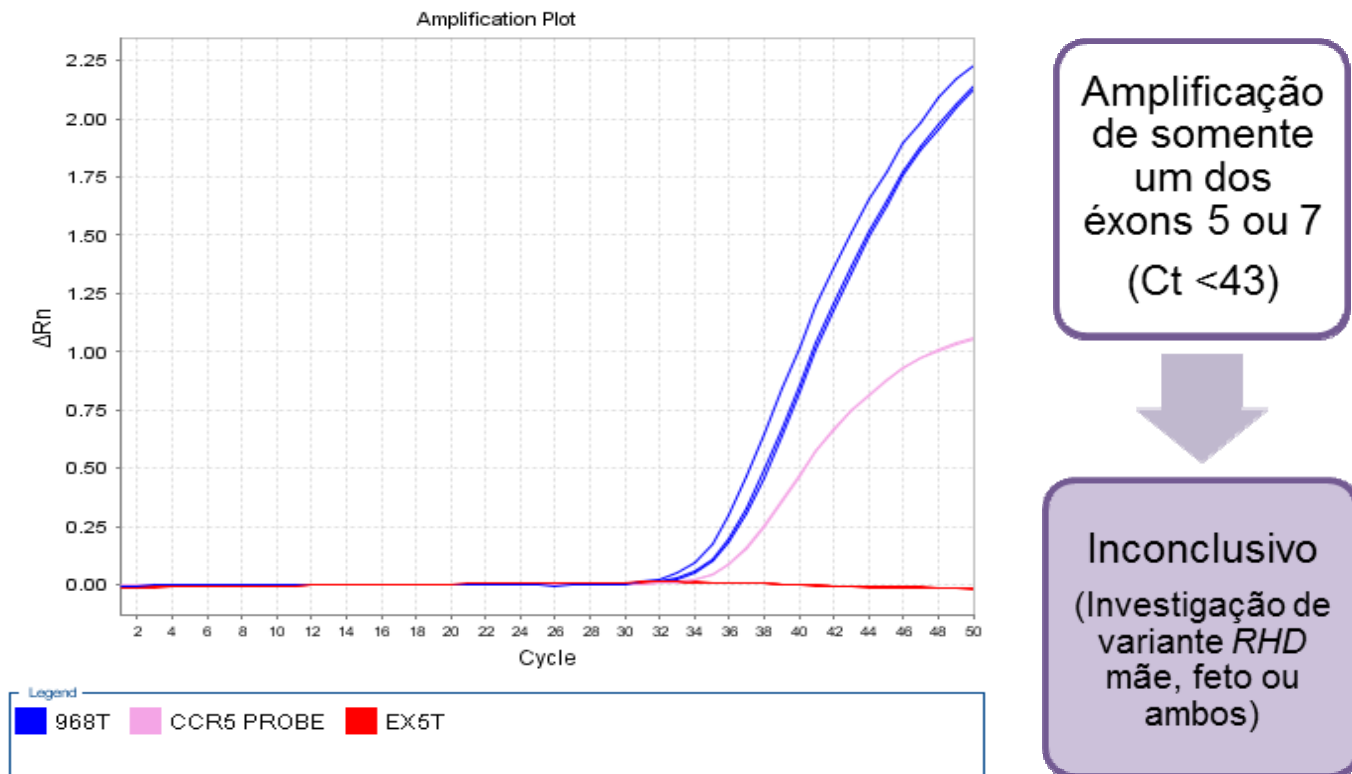

Figura 10 - Exemplo de resultado apresentado na PCR em tempo real para a variante $R H D$ (mãe, feto ou ambos)

Em azul,curva de amplificação do éxon 7; em vermelho, o éxon 5 e, em rosa, o CCR5. Amplificação do éxon 7 e CCR5 e ausência do éxon 5.

Os parâmetros de validação foram determinados pela comparação dos resultados conclusivos da genotipagem $R H D$ fetal, com os resultados do fenótipo RhD dos recém-nascidos.

Foram determinados a Sensibilidade (S), Especificidade (E), Acurácia (A), Valor Preditivo Positivo (VPP) e Valor Preditivo Negativo (VPN).

\section{Sensibilidade}

Total de resultados positivos na genotipagem $R H D$ fetal Total de RN com fenótipo RhD positivo + falso negativo

\section{Especificidade}

Total de resultados negativos na genotipagem $R H D$ fetal

Total de RN com fenótipo RhD negativo + falso positivo 


\section{Acurácia}

Total de resultados concordantes entre genotipagem e fenotipagem

Total de resultados

\section{Valor preditivo positivo}

Total de resultados positivos na genotipagem $R H D$ fetal

Total de RN com fenótipo RhD positivo + falso positivo $X 100$

Valor preditivo negativo

Total de resultados negativos na genotipagem $R H D$ fetal

Total de RN com fenótipo RhD negativo + falso negativo

\subsubsection{Investigação de variantes $R H D$}

As amostras que apresentaram amplificação em somente um dos éxons 5 ou 7 indicam uma variante $R H D$ na mãe, no feto ou em ambos. Nesses casos, foram realizados testes moleculares adicionais.

\subsubsection{Pseudogene RHD $\Psi$}

Indivíduos portadores do pseudogene $R H D \Psi$ são fenotipicamente equivalentes ao RhD negativo, pois os eritrócitos são totalmente despidos da proteína RhD. No entanto, possuem uma cópia desse gene, que se tornou inativo por meio de mutações e inserções.

Neste estudo, as amostras que apresentaram amplificação para o éxon 7 e ausência no éxon 5 foram submetidas à reação de PCR 
convencional, estratégia do primer reverso (éxon 4 insert/rev) que contém a junção do intron 3/éxon 4 formada apenas no pseudogene $R H D \Psi$. Para o controle interno da reação, foi utilizado o primer do $\mathrm{RH}^{*} \mathrm{C} / \mathrm{c}$ do gene RHCE (Tabela 6). Os primers foram baseados no estudo de Singleton et al. (2000) ${ }^{45}$. O protocolo de ensaio está descrito no anexo 4.

Tabela 6 - Sequência dos primers utilizados no ensaio multiplex para detecção do pseudogene $R H D \Psi$ em PCR convencional

\begin{tabular}{|c|c|c|}
\hline Primers & Sequência (5'-3') & Fragmento \\
\hline \multicolumn{3}{|l|}{ 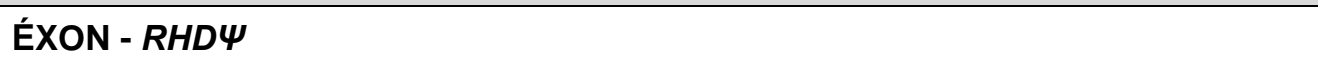 } \\
\hline Intron $3 /$ for $2^{45}$ & AAC CTG GGA GGC AAA TGT T & $250 \mathrm{pb}$ \\
\hline Éxon 4 insert/rev ${ }^{45}$ & AAT AAA ACC CAG TAAGTT CAT GTG G & \\
\hline \multicolumn{3}{|l|}{ ÉXON - RHCE } \\
\hline $\mathrm{c} / \mathrm{for}^{45}$ & TCG GCC AAG ATC TGA CCG & $177 \mathrm{pb}$ \\
\hline $\mathrm{c} / \mathrm{rev}^{45}$ & TGA TGA CCA CCT TCC CAG G & \\
\hline
\end{tabular}

Para a determinação do pseudogene RHD $\Psi$ em PCR convencional, o estudo de Singleton et al. $(2000)^{45}$ é mundialmente consagrado. Baseado nesse estudo, e considerando que, na população brasileira, a presença de indivíduos $R H D \Psi$ é aproximadamente $11 \%{ }^{46}$ notamos a necessidade de aprimorar o ensaio para o PCR em tempo real. Assim, para o presente estudo foram desenhados primers e sonda para o $R H D \Psi$ na PCR em tempo real (Tabela 7). Esse ensaio é inédito e ainda não foi descrito na literatura. 
Tabela 7 - Descrição dos pares de primers e sonda do pseudogene $R H D \Psi$, em PCR em tempo real

\begin{tabular}{ccccc}
\hline $\begin{array}{c}\text { Primers e } \\
\text { sondas }\end{array}$ & Sequência (5'-3') & reporter & quencher & Fragmento \\
5' & 3' & \\
\hline $\begin{array}{c}\text { Éxon } \boldsymbol{R H D} \boldsymbol{\Psi} \\
\text { Pseudo-F }\end{array}$ & TCA CTG CTC TTA CTG GGT & & & 62pb \\
Pseudo-R & CGT AGA TGT GCA TCA TGT T & & & \\
Pseudo -P & TET CAG ACC ACA TGA ACT TA CTG TTT & TET & MGB & \\
& & & & \\
\hline
\end{tabular}

O resultado obtido na $\mathrm{PCR}$ em tempo real para determinar $\mathrm{o}$ $R H D \Psi$, está apresentado na figura 11.

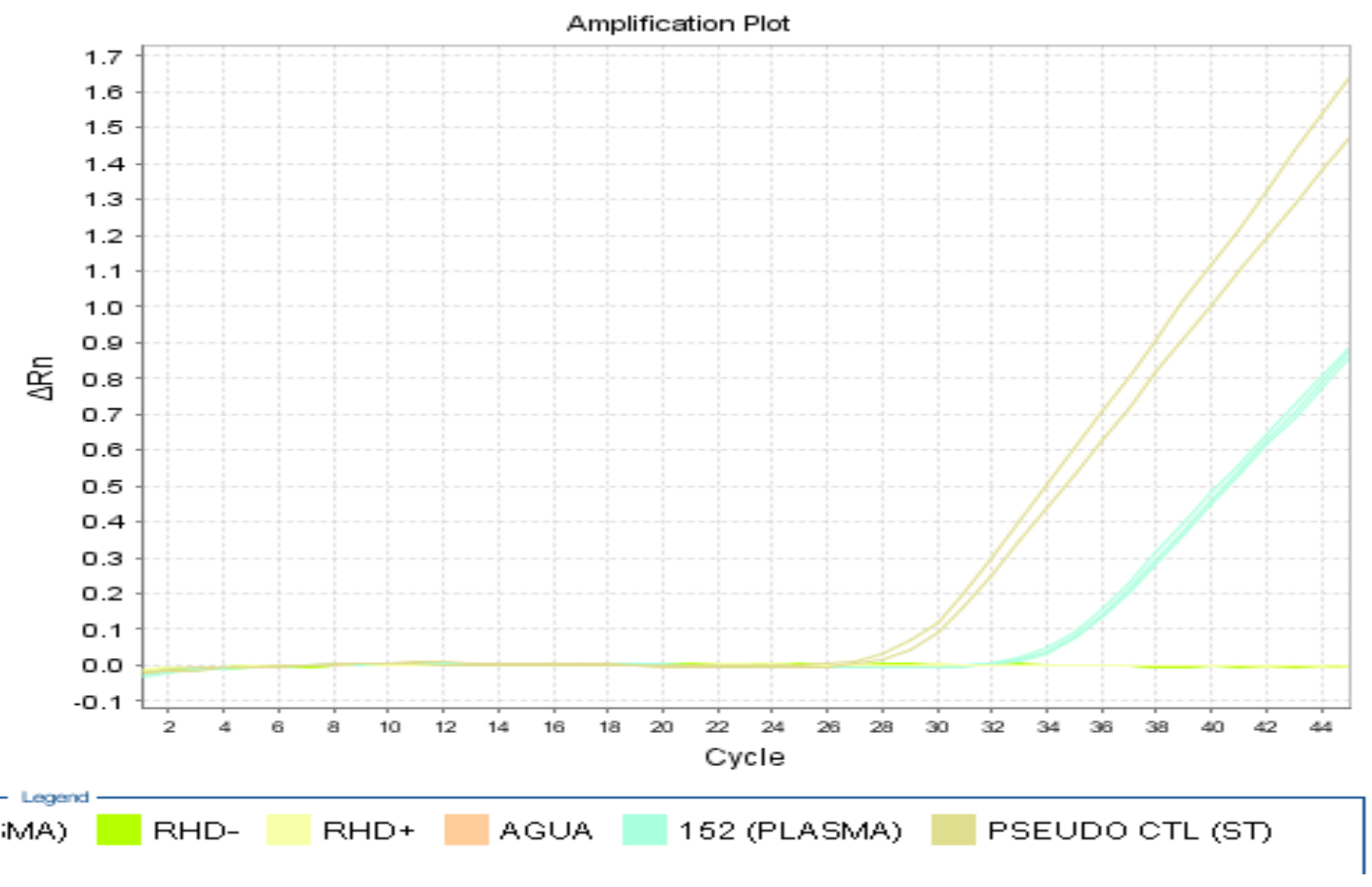

Figura 11 - Exemplo de resultado obtido na PCR em tempo real para determinar o RHD $\Psi$

Descrição das amostras testadas: no verde, indivíduo $R H D$-; no amarelo claro, indivíduo $R H D+$; no rosa, a água; no azul turquesa, amostra da gestante 152 (candidata à variante $R H D$ ); no bege, amostra de DNA obtido de sangue total de indivíduo $R H D \Psi$ (controle positivo). Observamos amplificação na amostra do indivíduo $R H D \Psi$ e na gestante. As amostras $R H D-, R H D+$ e água não amplificam nesse ensaio. 


\subsubsection{PCR multiplex RHD parcial}

Existem inúmeras variantes $R H D$ parcial descritas na literatura. Alguns $\mathrm{RhD}$ parciais podem apresentar-se fenotipicamente como RhD positivo ou $\mathrm{RhD}$ negativo, dependendo do $\mathrm{RhD}$ parcial considerado.

Neste estudo, os casos que apresentaram amplificação para o éxon 7, e ausência de amplificação no éxon 5 e $R H D \Psi$ indicam a presença de outra variante $R H D$.

Foi realizada, na amostra materna, a extração manual da camada de leucócitos, para determinar se a mãe era a variante RHD. Nessa extração, foi utilizado Brazol, protocolo descrito no anexo 5.

O DNA extraído foi submetido à reação de PCR convencional Multiplex RHD parcial, que avalia a presença dos éxons 3,4,5,6,7 e 9 do gene RHD. Esse ensaio é baseado no estudo de Maaskant-van Wijk ${ }^{113}$, descrito no anexo 4.

As amostras maternas que apresentaram ausência de amplificação de todos os éxons indicam que a mãe é verdadeiramente $R H D$ negativo. Dessa forma, o candidato à variante $R H D$ é o feto. 


\subsection{Fluxograma geral da metodologia}

Para facilitar a compreensão da metodologia desenvolvida neste estudo, foi elaborado um fluxograma geral do teste de genotipagem $R H D$ fetal no plasma materno (Figura 12).

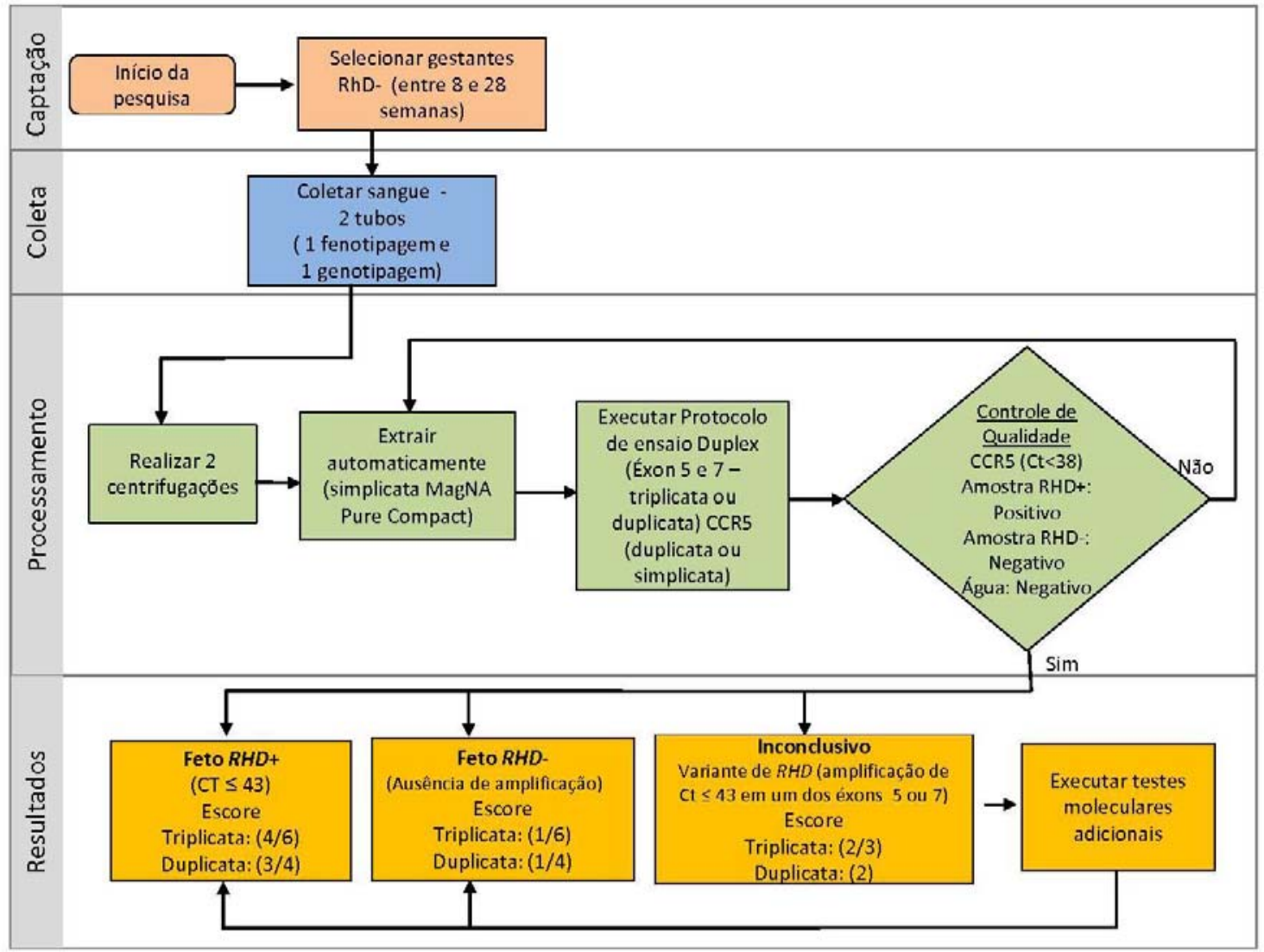

Figura 12 - Fluxograma geral do teste de genotipagem $R H D$ fetal 
No período de Maio de 2012 a Junho de 2014, foram coletadas amostras de 220 gestantes RhD negativo no Ambulatório da Clínica Obstétrica do HC-FMUSP. Na totalidade, $185(84,1 \%)$ atenderam os critérios de inclusão e 35 (15,9\%) foram excluídas da casuística pelos seguintes motivos:

- 16: amostras foram exauridas na padronização da metodologia;

- 11: óbito fetal;

- 5: perda de seguimento pós-natal;

- 3: gestantes fenotipicamente RhD positivo, foram equivocadamente transcritas na carteira do pré-natal como RhD negativo.

\subsection{Características gerais da população}

As características gerais da população em estudo estão descritas na tabela 8 . 
Tabela 8 - Características gerais da população em estudo

\begin{tabular}{|c|c|}
\hline & N (\%) / média \pm DP \\
\hline IDADE MATERNA & Mediana 30 \\
\hline \multicolumn{2}{|l|}{ ETNIA } \\
\hline Branca & $100(54,05 \%)$ \\
\hline Parda & $64(34,6 \%)$ \\
\hline Negra & $21(11,35 \%)$ \\
\hline NÚMERO DE GESTAÇÕES & $2,81 \pm 1,68$ \\
\hline Primigesta & $38(20,54 \%)$ \\
\hline Secundigesta & $57(30,82 \%)$ \\
\hline Tercigesta & $46(24,87 \%)$ \\
\hline Quartigesta & $18(9,72 \%)$ \\
\hline Quintagesta ou mais & $26(14,05 \%)$ \\
\hline PARTOS ANTERIORES & $1,23 \pm 1,21$ \\
\hline 0 & $56(30,28 \%)$ \\
\hline 1 & $71(38,38 \%)$ \\
\hline 2 & $34(18,38 \%)$ \\
\hline 3 & $12(6,48 \%)$ \\
\hline 4 & $7(3,78 \%)$ \\
\hline 5 & $5(2,70 \%)$ \\
\hline ABORTAMENTO ANTERIOR & $0,59 \pm 1,28$ \\
\hline 0 & $123(66,50 \%)$ \\
\hline 1 & $45(24,32 \%)$ \\
\hline 2 & $6(3,24 \%)$ \\
\hline 3 & $4(2,16 \%)$ \\
\hline 4 & $3(1,62 \%)$ \\
\hline 5 ou mais & $4(2,16 \%)$ \\
\hline IDADE GESTACIONAL & $20,4 \pm 5,61$ \\
\hline 1 TRIMESTRE (8 a 13 semanas) & $32(17,30 \%)$ \\
\hline 2 TRIMESTRE (14-27 semanas) & $136(73,51 \%)$ \\
\hline 3 TRIMESTRE (28 semanas) & $17(9,19 \%)$ \\
\hline \multicolumn{2}{|l|}{ ALOIMUNIZADA } \\
\hline SIM & $65(35,13 \%)$ \\
\hline NÃO & $120(64,87 \%)$ \\
\hline \multicolumn{2}{|l|}{ ANTICORPO } \\
\hline 1 & $43 / 65(66,16 \%)$ \\
\hline 2 & $17 / 65(26,15 \%)$ \\
\hline 3 ou mais & $5 / 65(7,69 \%)$ \\
\hline \multicolumn{2}{|l|}{ DOENÇA ASSOCIADA } \\
\hline SIM & $68(36,76 \%)$ \\
\hline NÃO & $117(63,24 \%)$ \\
\hline
\end{tabular}


Na população estudada, a média da idade materna foi de 30 anos, com variação entre 15-43 anos (mediana de 30 anos). Em relação ao número de gestações, a média foi de 2,81, com o mínimo de 1 e máximo de 9 gestações (mediana de 2 gestações). A idade gestacional variou de 8-28 semanas, com média de 20,4 e mediana de 21 semanas.

Foi observado que 68 (36,76\%) apresentaram alguma doença associada como hipertensão, diabetes, hipo ou hipertiroidismo, entre outras patologias.

\subsection{Resultados da PCR em tempo real para o gene RHD em comparação com o fenótipo RhD do recém-nascido}

O teste de genotipagem $R H D$ fetal foi baseado no ensaio duplex (éxon 5 e 7) e analisado nas amostras de 185 gestantes. Na totalidade, 166 foram analisadas em triplicata e 19, em duplicata.

O ensaio do CCR5 também foi analisado nas amostras das 185 gestantes: 153 em duplicata e 32, em simplicata.

A tabela 9 apresenta os resultados do teste de genotipagem $R H D$ fetal, baseados na presença ou ausência de amplificação na PCR em tempo real juntamente com a classificação em escores comparados com o fenótipo do recém-nascido. 
Tabela 9 - Resultados por classificação em escores, baseados na presença ou ausência de amplificação em comparação ao fenótipo do recém-nascido

\begin{tabular}{|c|c|c|c|c|c|c|}
\hline \multicolumn{3}{|l|}{$\begin{array}{l}\text { Genótipo } \\
\text { Éxon } 5 \text { e } 7\end{array}$} & \multicolumn{2}{|c|}{$\begin{array}{c}\text { RhD- } \\
\text { Réplicas }\end{array}$} & \multicolumn{2}{|c|}{$\begin{array}{c}\text { RhD+ } \\
\text { Réplicas }\end{array}$} \\
\hline \multirow{2}{*}{ ESCORE } & & \multirow{2}{*}{$\mathbf{N}$} & 2 & 3 & 2 & 3 \\
\hline & & & réplicas & réplicas & réplicas & réplicas \\
\hline Negativo & 0 & 50 & 4 & 46 & - & - \\
\hline Negativo & 1 & - & - & - & - & - \\
\hline Inconclusivo & 2 & - & - & - & - & - \\
\hline Inconclusivo & 3 & 11 & - & 5 & 4 & 2 \\
\hline Positivo & 4 & 19 & - & - & 11 & 8 \\
\hline Positivo & 5 & 24 & & - & & 24 \\
\hline Positivo & 6 & 81 & & - & & 81 \\
\hline TOTAL & & 185 & 4 & 51 & 15 & 115 \\
\hline
\end{tabular}

O método de classificação por escores facilita a interpretação do teste quando apresenta principalmente discordância entre as réplicas testadas.

Podemos observar, na tabela demarcada em amarelo, que 50 casos não apresentaram amplificação na PCR em tempo real e foram classificados como 0 ponto, resultado negativo; 128 casos, demarcados com a cor verde, apresentaram amplificação na PCR em tempo real e foram classificados com 4, 5 e 6 pontos, resultado positivo; 7 casos demarcados com a cor rosa apresentaram somente 3 pontos, e foram classificados como inconclusivos.

A tabela 10 apresenta os resultados das distribuições das amplificações dos éxons 5 e 7, comparados com o fenótipo do recémnascido. 
Tabela 10 - Tabela de contingência das distribuições dos resultados das amplificações dos éxons 5 e 7 em relação ao fenótipo do recém-nascido

\begin{tabular}{|c|c|c|c|c|c|}
\hline \multirow{3}{*}{ Fenótipo RN } & \multicolumn{4}{|c|}{ Genótipo fetal } & \multirow{3}{*}{ Total } \\
\hline & \multicolumn{2}{|c|}{ Éxon 5} & \multicolumn{2}{|c|}{ Éxon 7} & \\
\hline & - & + & - & + & \\
\hline Negativo & 55 & 0 & 50 & 5 & 55 \\
\hline Positivo & 2 & 128 & 0 & 130 & 130 \\
\hline TOTAL & \multicolumn{2}{|c|}{185} & \multicolumn{2}{|c|}{185} & 185 \\
\hline
\end{tabular}

Na tabela acima é possível observar que nos 7 casos inconclusivos houve amplificação somente no éxon 7 e ausência no éxon 5 . Desse total, 5 são fenotipicamente RhD negativo e 2 fenotipicamente RhD positivo.

A tabela 11 apresenta os resultados das amplificações em comparação com o fenótipo do recém-nascido, e as porcentagens encontradas na população em estudo.

Tabela 11 - Resultados comparativos entre genotipagem e fenotipagem e a distribuição das porcentagens na população em estudo

\begin{tabular}{lccc}
\hline Genótipo (Éxon 5 e 7) & \multicolumn{3}{c}{ Fenótipo RN } \\
& RhD - & RhD + & $\mathrm{N}(\%)$ \\
\hline Negativo & $50(90,9)$ & - & $50(27,1)$ \\
Inconclusivo & $5(9,1)$ & $2(1,5)$ & $7(3,7)$ \\
Positivo & - & $128(98,5)$ & $128(69,2)$ \\
TOTAL & 55 & 130 & 185 \\
\hline
\end{tabular}


$\mathrm{Na}$ tabela acima é explícito que não houve nenhum caso de falso negativo, ou falso positivo. Os casos inconclusivos foram detectados e analisados individualmente por outros testes moleculares que serão descritos neste estudo.

Como já ressaltado, o grupo de aloimunização materno-fetal da Clínica Obstétrica do HC-FMUSP é um centro terciário do SUS para atendimento de alto risco. A tabela 12 apresenta os resultados das gestantes aloimunizadas e não aloimunizadas em comparação com os resultados da genotipagem $R H D$ fetal.

Tabela 12 - Resultados encontrados entre gestantes aloimunizadas e não aloimunizadas em comparação ao genótipo RHD fetal

\begin{tabular}{lccc}
\hline Resultado & $\mathbf{N}(\%)$ & RHD & RHD + \\
\hline Aloimunizada pelo Anti-D & $\mathbf{5 7}(\mathbf{3 0 , 9 )}$ & $\mathbf{1 5}$ & 42 \\
Outros aloanticorpos & $\mathbf{8}(\mathbf{4 , 3 )}$ & $\mathbf{4}$ & $\mathbf{4}$ \\
Não aloimunizadas & $\mathbf{1 2 0 ( 6 4 , 8 )}$ & $\mathbf{3 6}$ & $\mathbf{8 4}$ \\
TOTAL & 185 & 55 & 130 \\
\hline
\end{tabular}

Nesta tabela, vale ressaltar que 15 gestantes aloimunizadas pelo anti$D$, realizaram pré-natal de alto risco sem necessidade pelo fato de o genótipo do feto ser RHD negativo.

Do grupo de gestantes não aloimunizadas, 36 receberam imunoglobulina anti-D desnecessariamente. 
Para confirmar se o teste é altamente confiável, foram calculados os valores da sensibilidade, especificidade, valor preditivo positivo, valor preditivo negativo e acurácia dos resultados das amplificações dos éxons 5 e 7 em relação aos trimestres gestacionais, esses valores estão apresentados na tabela 13.

Tabela 13 - Cálculo das sensibilidades (S), especificidades (E), valores preditivos positivos (VPP), valores preditivos negativos (VPN) e acurácia $(A)$ dos resultados das amplificações dos éxons 5 e 7 em comparação aos trimestres gestacionais

\begin{tabular}{lcccccc}
\hline $\begin{array}{l}\text { Trimestre } \\
\text { gestacional }\end{array}$ & $\begin{array}{l}\text { Éxons } \\
\mathbf{5} \text { e } \mathbf{7}\end{array}$ & $\mathbf{S ~ ( \% )}$ & E (\%) & VPP (\%) & VPN (\%) & A (\%) \\
\hline $\mathbf{8 - 1 3}$ semanas & 32 & 100 & 100 & 100 & 100 & 100 \\
$\mathbf{1 4 - 2 7}$ semanas & 136 & 100 & 100 & 100 & 100 & 100 \\
$\mathbf{2 8}$ semanas & 17 & 100 & 100 & 100 & 100 & 100 \\
\hline
\end{tabular}

É notável observar que o teste apresentou acurácia de 100\% para ambos os éxons nos três trimestres gestacionais. Para a realização do cálculo foram considerados somente os resultados positivo e negativo, e nesses grupos não houve discordância entre genotipagem e fenotipagem.

Os resultados inconclusivos foram excluídos dos cálculos já que se trata de possíveis variantes $R H D$, as quais devem ser investigadas e analisadas cautelosamente, pois o teste, pelo seu desenho, acusa os inconclusivos. 


\subsection{Resultados das PCR em tempo real e PCR convencional para o gene $R H D$ nos casos inconclusivos}

Para predizer o fenótipo RhD fetal nos sete casos com genotipagem RHD inconclusivo, onde houve amplificação somente do éxon 7 , foram necessários testes moleculares adicionais.

Como já foi descrito neste estudo, o pseudogene $R H D \Psi$ é um gene silencioso e frequente na população brasileira, e no ensaio SAFE se comporta exatamente dessa forma: éxon 7 positivo, éxon 5 negativo. Portanto, os setes casos foram submetidos ao ensaio do RHD $\Psi$ em PCR convencional, utilizando DNA extraído de amostra plasmática. Os resultados da PCR convencional para o ensaio do $R H D \Psi$ estão apresentados na figura 13.

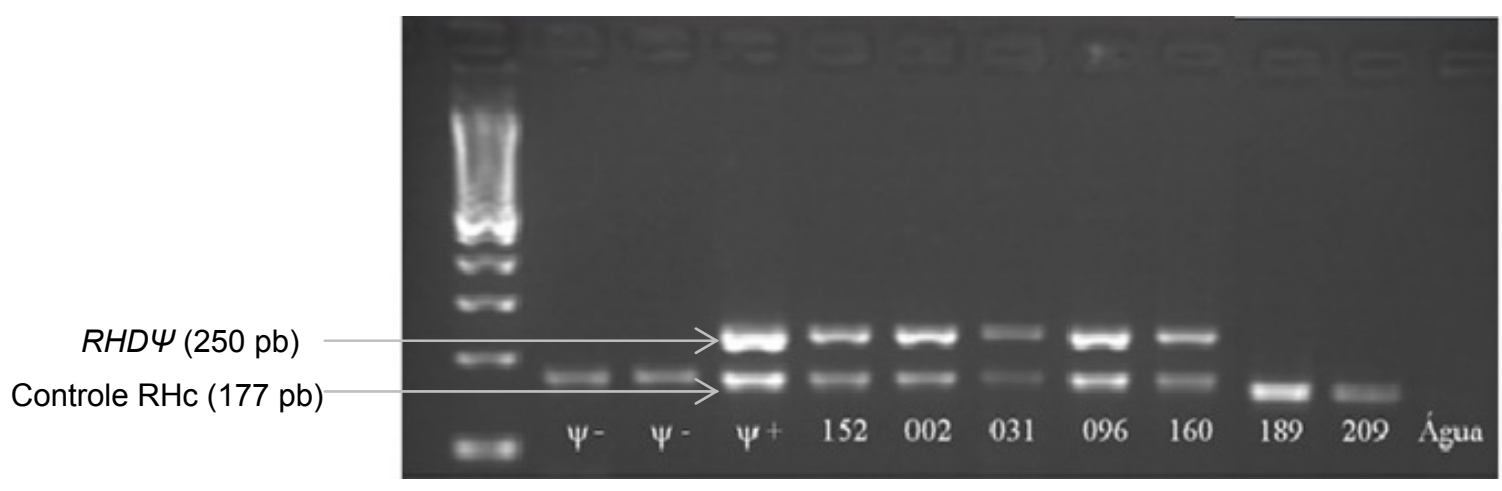

Figura 13 - Ensaio da PCR convencional para o pseudogene RHD $\Psi$

Primeira fileira $=$ Marcador de peso molecular 100pb ladder. Segunda e terceira fileira= DNA plasmático de indivíduo $R H D \Psi$. Quarta fileira = DNA plasmático de indivíduo RHD+. Quinta a décima primeira fileira = DNA plasmático das amostras 152, 002, 031, 096, 160, 189 e 209. Décima segunda fileira = Água. 
Podemos observar que as amostras, 152, 002, 031, 096 e 160 confirmaram a presença do pseudogene RHD $\Psi$. Entretanto, como os DNAs foram obtidos de amostras plasmáticas, não é possível concluir se a mãe ou o feto é o candidato ao gene silencioso. Contudo, independente de qual indivíduo possui o $R H D \Psi$, podemos concluir que são fenotipicamente $\mathrm{RhD}$ negativo.

As amostras 189 e 209 não apresentaram amplificação para o $R H D \Psi$, sugerindo outras variantes $R H D$.

Como objetivo específico deste estudo, padronizamos o ensaio em PCR em tempo real para o pseudogene $R H D \Psi$, a fim de comprovar sua eficiência frente ao PCR convencional.

Nos sete casos, foi extraído, amostra da camada de leucócitos materna, por método de extração manual e submetido ao ensaio de PCR em tempo real.

A tabela 14 apresenta os resultados encontrados na PCR em tempo real para o $R H D \Psi$, em comparação com o fenótipo do recém-nascido.

Tabela 14 - Resultados do ensaio do $R H D \Psi$ na PCR em tempo real por valores de amplificação, das amostras maternas comparadas ao fenótipo do recém-nascido

\begin{tabular}{|c|c|c|c|c|c|c|}
\hline AMOSTRA & $\begin{array}{l}\text { TIPAGEM } \\
\text { MATERNA }\end{array}$ & $\begin{array}{l}\text { TIPAGEM } \\
\text { RN }\end{array}$ & $\begin{array}{c}R H D \Psi \\
\text { PSEIUDO_1 }\end{array}$ & $\begin{array}{c}R H D \Psi \\
\text { PSEIUDO_2 }\end{array}$ & $\begin{array}{c}R H D \Psi \\
\text { PSEIUDO_3 }\end{array}$ & $\begin{array}{c}\text { RHD } \\
\text { PSEIUDO } \\
\text { _media }\end{array}$ \\
\hline 2 & O RhD- & O RhD- & 25,80 & 25,50 & 25,48 & 25,59 \\
\hline 31 & B RhD- & B RhD- & 22,28 & 22,26 & 22,37 & 22,30 \\
\hline 96 & A RhD- & AB RhD- & 24,37 & 24,62 & 24,94 & 24,64 \\
\hline 152 & A RhD- & A RhD- & 22,59 & 23,05 & 22,43 & 22,69 \\
\hline 160 & A RhD- & AB RhD- & 20,97 & 21,47 & 21,47 & 21,30 \\
\hline 189 & A RhD- & B RhD+ & ${ }^{*} \mathrm{ND}$ & ${ }^{*} \mathrm{ND}$ & & ${ }^{*} \mathrm{ND}$ \\
\hline 209 & A RhD- & O RhD+ & ${ }^{*} \mathrm{ND}$ & ${ }^{*} \mathrm{ND}$ & & ${ }^{*} \mathrm{ND}$ \\
\hline
\end{tabular}

*ND: Não Determinado = não amplificado 
Podemos observar que os resultados obtidos na PCR em tempo real foram concordantes com a metodologia padrão ouro, o PCR convencional.

E evidente que as cinco amostras (002, 031, 096, 152 e 160) apresentaram amplificação para $\circ R H D \Psi$, indicando que as mães são $R H D \Psi$. Em contrapartida, as duas amostras (189 e 209) não apresentaram amplificação para o $R H D \Psi$, indicando ausência do gene silencioso. Essas amostras foram submetidas ao ensaio do PCR multiplex para a investigação de outras variantes $R H D$.

As amostras 189 e 209 foram submetidas ao ensaio multiplex $R H D$ parcial para a análise dos éxons 3,4,5,6,7 e 9. A figura 14 apresenta os resultados do ensaio de multiplex $R H D$ em PCR convencional.

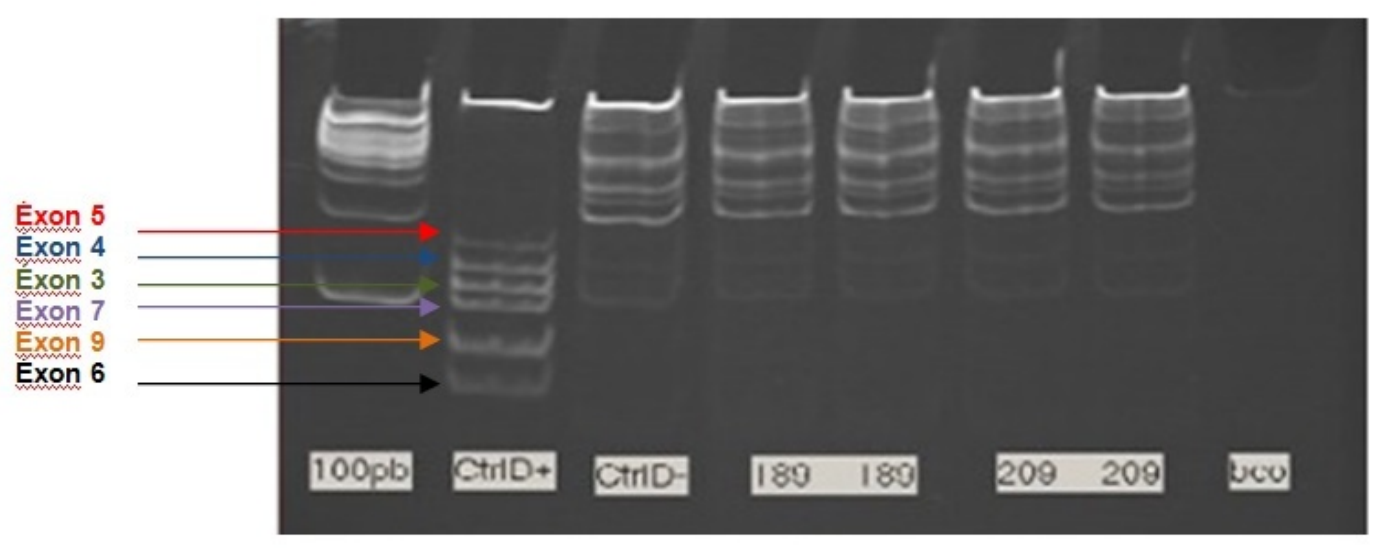

Figura 14 - Multiplex $R H D$ parcial

Peso molecular: Éxon 5 (157 pb); Éxon 4 (126 pb); Éxon 3 (111 pb); Éxon 7 ( 96 pb); Éxon $9(71 \mathrm{pb})$ e Éxon $6(57 \mathrm{pb})$. Primeira fileira = Marcador de peso molecular $100 \mathrm{pb}$ ladder. Segunda e terceira fileira= DNA da camada de leucócitos de indivíduo $R H D+$ e $R H D$-. Quarta a sétima fileira= DNA da camada de leucócitos materna 189 e 209. Oitava fileira = Água. 
Podemos observar que as amostras 189 e 209 não apresentaram amplificação para os éxons testados. A partir desse ensaio, concluímos que as duas mães são verdadeiramente $R H D$ negativo, e que os candidatos a variantes $R H D$ parcial são os fetos. Nesses casos, não foi possível aferir o genótipo fetal durante o pré-natal. 


\subsection{Custo do teste de genotipagem RHD fetal por método de extração automatizada}

Para avaliar a viabilidade financeira da implantação do teste de genotipagem $R H D$ fetal por método de extração automatizada no serviço público de saúde, especificamente no HC-FMUSP, foi calculado o custo do teste levando em conta apenas gasto com reagentes e materiais de uso único como tubos e ponteiras descartáveis. As especificações e valores estão demonstrados na tabela 15.

Tabela 15 - Custo do teste de genotipagem RHD fetal por método de extração automatizada

\begin{tabular}{lc}
\hline \multicolumn{1}{c}{ Descrição dos reagentes } & Valor por reação \\
\hline Extração automatizada: MagNa Pure Compact (Kit & $\mathrm{R} \$ 50,0$ \\
large volume) & $\mathrm{R} \$ 4,8$ \\
TaqMan Universal PCR master Mix $(5 \mathrm{~mL})$ & $\mathrm{R} \$ 0,2$ \\
Primer: 940F (100 nM) & $\mathrm{R} \$ 0,2$ \\
Primer: 1064R (100 nM) & $\mathrm{R} \$ 0,5$ \\
Sonda: 968T (100 nM) & $\mathrm{R} \$ 0,2$ \\
Primer: ex5F (100 nM) & $\mathrm{R} \$ 0,2$ \\
Primer: ex5R (100 nM) & $\mathrm{R} \$ 0,5$ \\
Sonda: ex5T (100 nM) & $\mathrm{R} \$ 0,2$ \\
Primer: CCR5F (100 nM) & $\mathrm{R} \$ 0,2$ \\
Primer: CCR5R (100 nM) & $\mathrm{R} \$ 0,5$ \\
Sonda: CCR5 5uM (100 nM) & $\mathrm{R} \$ 1,0$ \\
Ponteiras com filtro & $\mathrm{R} \$ 1,0$ \\
Tubo de coleta & $\mathrm{R} \$ 59,50$ \\
Total & \\
\hline \hline
\end{tabular}


Para comprovarmos que o valor do teste de genotipagem $R H D$ fetal é acessível ao sistema público de saúde, levantamos os valores tabela dos pagos pelos SUS para os testes imuno-hematológicos e profilaxia, abaixo os valores apresentados na tabela 16.

Tabela 16 - Custo dos testes imuno-hematológicos e profilaxia envolvidos no acompanhamento das gestantes RhD negativo

\begin{tabular}{ll}
\hline Testes Imunohematológicos & Valor por exame \\
\hline Triagem (TA, AGH, LISS e Enzima) $^{114}$ & $\mathrm{R} \$ 23,16$ \\
Painel (LISS e Enzima) & $\mathrm{R} \$ 21,3$ \\
Titulação $^{14}$ & $\mathrm{R} \$ 5,79$ \\
TOTAL & $\mathrm{R} \$ 50,25$ \\
Profilaxia $_{\text {Imunoglobulina Anti-D }^{115}}$ & Valor por dose \\
\hline
\end{tabular}

Comparando as duas tabelas podemos concluir que o valor do teste molecular de determinação do genótipo fetal é compatível com um teste sorológico imuno-hematológico. Além disso é, em média, três vezes mais barato que a profilaxia. 
Gestantes RhD negativo apresentam uma potencialidade para a aloimunização $\mathrm{RhD}$ com subsequente DHPN. Podemos afirmar que, na Medicina Fetal, essa doença foi desvendada desde sua fisiopatologia, diagnóstico, tratamentos, estratégias de prevenção e o conhecimento do genótipo fetal.

O último marco da história da DHPN-RhD só foi possível a partir de 1997, após a descoberta de DNA fetal livre no plasma materno, que abriu possibilidades de diagnóstico pré-natal não invasivo ${ }^{22,24}$.

No decorrer dos 18 anos, pesquisadores de todo o mundo não mediram esforços para a investigação de uma metodologia ideal. Entretanto, para alcançar uma alta sensibilidade e especificidade do teste, alguns fatores foram levados em consideração, tais como: o método de extração do DNA, métodos de detecção e as diferentes regiões alvo ${ }^{24}$.

O presente estudo, baseado nos conhecimentos prévios da literatura, apresenta um diferencial inédito no Brasil. É o primeiro estudo de determinação do genótipo $R H D$ fetal utilizando uma metodologia de extração automatizada, com o equipamento robótico MagNa Pure Compact (Roche), com o Kit LV que extrai $1 \mathrm{~mL}$ de plasma.

A extração realizada por equipamentos robóticos proporciona reprodutibilidade, maior rendimento, redução do tempo de processo, além de minimizar possíveis erros humanos ${ }^{31,82,116}$.

Huang e colaboradores (2005) ${ }^{116}$ demonstraram que este mesmo equipamento apresentou maior eficiência de extração quando comparado à 
extração manual. Além disso, inúmeros estudos ressaltam que a etapa de extração é fundamental para garantir altas concentrações de DNA, e que faz diferença ao final de todo o processo ${ }^{31,82,73}$.

Participaram deste estudo 185 gestantes que englobaram os três trimestres gestacionais e apresentaram acurácia de 100\%, independente da idade gestacional. Obtivemos $128(69,2 \%)$ fetos classificados como $R H D$ positivo, $50(27,1 \%)$, como $R H D$ negativo e $7(3,7 \%)$ como inconclusivos. Não houve nenhum caso falso-negativo ou falso-positivo.

Apesar de o presente estudo não apresentar nenhum caso de falsonegativo, vale ressaltar que tal situação está relacionada diretamente com a coleta de sangue precoce, com 4-5 semanas de gestação ${ }^{98,117}$, e que o resultado não é confiável antes de 7 semanas devido à baixa concentração de DNA fetal ${ }^{118}$. Outras circunstâncias que podem levar a resultado desfavorável são as condições inadequadas de transporte, processamento, centrifugação e estocagem ${ }^{25}$.

Neste estudo, a idade mínima foi de 8 semanas de gestação e não foram observados resultados errôneos. Porém para uma futura aplicação do teste na prática clínica, sugerimos a coleta a partir de 10-11 semanas. Essa idade é preconizada em outros serviços que realizam o teste de rotina, pois garante um resultado clinicamente confiável ${ }^{34}$.

Como já descrito, este estudo não apresentou nenhum resultado falso-positivo. Entretanto, é possível deparar com esta situação principalmente quando estamos diante de uma população intensamente miscigenada como a brasileira. Os casos de falso-positivo estão 
relacionados principalmente com as escolhas das regiões alvo e contaminação laboratorial por amplicons.

Como já ressaltado, o sistema sanguíneo Rh apresenta inúmeros polimorfismos, e isso dificulta uma simples predição do fenótipo $R h D$, baseado no genótipo. Dessa forma, a escolha dos éxons é uma estratégia para englobar as principais variações genéticas encontradas nas populações.

Vários éxons do gene $R H D$ já foram estudados tais como, os éxons 4, $5,6,7$ e $10^{23,27,86}$. Alguns autores recomendam estudar ao menos duas regiões do gene simultaneamente, além de realizar os ensaios em triplicatas com controles positivos, negativos e de DNA total ${ }^{27,86}$.

Outros estudos brasileiros semelhantes como de Machado et al. (2006) ${ }^{19}$, Chinen et al. (2010) ${ }^{104}$, Amaral et al. (2011) ${ }^{105}$ e Schimidt et al. $(2014)^{110}$, analisaram outras regiões do $R H D(4$ e 10), (7 e 10), (4, 5 e 10) e (5 e 7), e obtiveram acurácia de $97,3 \%, 98 \%, 100 \%$ e $100 \%$.

Interessantemente, neste estudo, foram detectados sete casos inconclusivos (3,7\%), no qual houve amplificação somente do éxon 7.

Esses resultados inconclusivos são provenientes de variantes $R H D$ que normalmente são encontradas em populações multiétnicas. A variante genotípica mais comum é o $R H D \Psi$ frequentemente encontrado em negros, e comporta-se como um gene silencioso e o indivíduo apresenta-se fenotipicamente como RhD negativo.

Em um estudo similar realizado com populações multiétnicas, foram detectados sete casos inconclusivos (2,5\%), compatíveis com RHD $\Psi$ e $R H D$ 
parcial categoria VI. Após o nascimento, foi confirmado que três eram provavelmente DVI tipo 1 ou 4 , e quatro compatíveis com RHD-CE-D ${ }^{109}$.

Entretanto, no Brasil, a análise do $R H D \Psi$ é essencial para evitar resultados falso-positivos. Em nosso estudo, os sete casos foram submetidos à análise do ensaio específico para o $R H D \Psi$ em PCR convencional (Figura 13), metodologia padrão ouro para a deteç̧ão dessa variante, sendo que cinco casos confirmaram a presença desse gene silencioso. Todavia, independente de quem possuía a variante mãe ou feto, ambos são fenotipicamente $\mathrm{RhD}$ negativo.

Compreendendo que estamos em meio a uma população altamente miscigenada e que a presença do $R H D \Psi$ é algo inegável para evitar resultados falso-positivos, desenvolvemos um ensaio em PCR em tempo real para a detecção dessa variante. O ensaio na PCR em tempo real é mais rápido e menos trabalhoso quando comparado ao PCR convencional, já que não necessita da etapa de eletroforese.

Futuramente, com a aplicação do teste na prática clínica, o ensaio do $R H D \Psi$ em PCR em tempo real facilitará a assistência às gestantes $\mathrm{RhD}$ negativo, pois aquelas que apresentarem amplificação para o $R H D \Psi$, teoricamente, não terão necessidade de, receber a profilaxia. Entretanto, este é um ensaio pioneiro com análise de poucas amostras. Para garantir que essas mulheres não devam receber profilaxia, é necessário um estudo mais abrangente que comprove tal afirmação. Dessa forma, sugerimos que os casos inconclusivos pela presença do $R H D \psi$ devam receber profilaxia 
mesmo sendo desnecessária, pois é prudente a precaução nessa etapa inicial.

Dos sete casos inconclusivos, dois não apresentaram amplificação para o RHD $\Psi$, indicando outra variante $R H D$. Foram analisadas, inicialmente, as amostras maternas para verificar a presença ou ausência de outras variantes $R H D$, submetidas à análise das regiões 3-9 do gene $R H D$ (Figura 14).

Durante o pré-natal, os casos inconclusivos que indicam que o feto é o candidato à variante $R H D$ parcial devem receber a profilaxia. A comprovação do tipo de $R H D$ variante só será possível após o nascimento.

Para determinar o tipo de $R H D$ variante procede-se à coleta pós-natal dos recém-nascidos e de seus progenitores paternos.

Nesses casos, a identificação das variantes $R H D$ é primordial, pois é obrigação dos profissionais da saúde fornecer orientação sobre eventual necessidade de suporte hemoterápico. Se esses indivíduos possuem algum tipo de variante $R H D$ que possa causam aloimunização devem receber transfusão de hemácias do tipo RhD negativo. Além disso, crianças do sexo feminino que futuramente ficarão grávidas já estarão cientes do seu tipo sanguíneo, facilitando ao obstetra seu acompanhamento durante o pré-natal.

Em relação ao custo do teste, é notório que gestores de saúde pública visam os testes moleculares como exames de alto custo, pois exigem inovação tecnológica e pessoal especilizado. Entretanto, podemos constatar na tabela 15 , que o custo da genotipagem $R H D$ fetal no plasma materno pode ser realizado por $\mathrm{R} \$ 59,50$. Vale salientar, que mais de $80 \%$ do 
custo do teste é devido à extração, se consideramos que nos grandes centros hospitalares a compra de materiais é em grande volume, e possível alcançar um valor ainda mais acessível do teste.

Em nosso estudo, 40 casos de gestantes não aloimunizadas que foram classificadas com feto $R H D$ negativo não necessitariam de profilaxia. Considerando que essas mulheres receberam pelo menos 1 dose de imunoglobulina anti-D no valor R\$ $160,55^{115}$ o gasto foi, no mínimo, de $\mathrm{R} \$$ 6.422.00. Se considerarmos os gastos do teste para todas as gestantes, $185 \times 59,50=\mathrm{R} \$ 11.007,50$. Portanto, a economia da profilaxia por si só não é custo-efetivo, mas quando somada aos custos dos testes que monitoram anticorpos, e ao atendimento da gestação de alto risco, o teste torna-se custo-benefício.

Além disso, a imunoglobulina é um hemoderivado proveniente de indivíduos $\mathrm{RhD}$ negativo que se submetem à exposição ao antígeno $\mathrm{RhD}$ e desenvolvem o anti-D. Devido à maneira rudimentar que se induz à formação desses anticorpos, o número de pessoas que se sujeitam a esse processo diminui a cada dia ${ }^{28}$.

Porém, não é somente o aspecto econômico que deve ser ressaltado. O soro desses indivíduos sensibilizados pode ser veículo de contaminação, apesar de haver uma intensa vigilância e grandes melhorias no rastreamento sorológico dos doadores ${ }^{28}$. Há relatos de pacientes que receberam a imunoglobulina anti-D e desenvolveram hepatite $C^{119,120}$.

No estudo, observamos 15 gestantes aloimunizadas por anti-D que apresentam resultado da genotipagem $R H D$ negativo. 
Realmente é difícil mensurar os gastos públicos com exames laboratoriais (identificação de anticorpos irregulares e titulação), exames de ultrassonografia, além da ocupação do serviço terciário de saúde e de seus profissionais especializados. Ademais, gastos financeiros da gestante com transporte, alimentação, dia de serviço perdido, em suma, o valor incalculável, da parte emocional e afetiva das mães e de seus familiares, acreditando estar em um gestação de alto risco.

É notório que o teste de determinação do genótipo $R H D$ fetal por método não invasivo apresenta benefícios incalculáveis para o meio clínico, científico e social.

Na Holanda e na Dinamarca, as gestantes RhD negativo só recebem profilaxia após a confirmação do genótipo $R H D$ fetal. Tais países foram pioneiros na implantação do teste de genotipagem $R H D$ fetal ${ }^{31,105}$.

Haas e colaboradores (2012) ${ }^{121}$, no estudo de implantação do teste, ressaltam a importância da centralização e a logística para um centro de referência, equipe multiprofissional envolvida (como obstetras, ginecologistas, pediatras e profissionais do laboratório), um cadastro efetivo para acompanhamento do pré e pós-natal das gestantes, além de um sistema de registro central dos resultados obtidos nos testes moleculares e nos testes sorológicos (sangue de cordão).

Devido à alta acurácia e aplicação confiável do teste, a Holanda, desde janeiro de $2013^{120}$, e a Dinamarca, desde janeiro de $2014^{24}$, não realizam mais teste sorológico em sangue de cordão umbilical para determinar o fenótipo RhD do recém-nascido. 
Enfim, frente à realidade de outros países e serviços, e considerando que a Clínica Obstétrica do HC-FMUSP é referência nacional e internacional, sugerimos um fluxograma para o acompanhamento das gestantes $\mathrm{RhD}$ negativo baseado no teste de genotipagem RHD fetal (Figura 15).

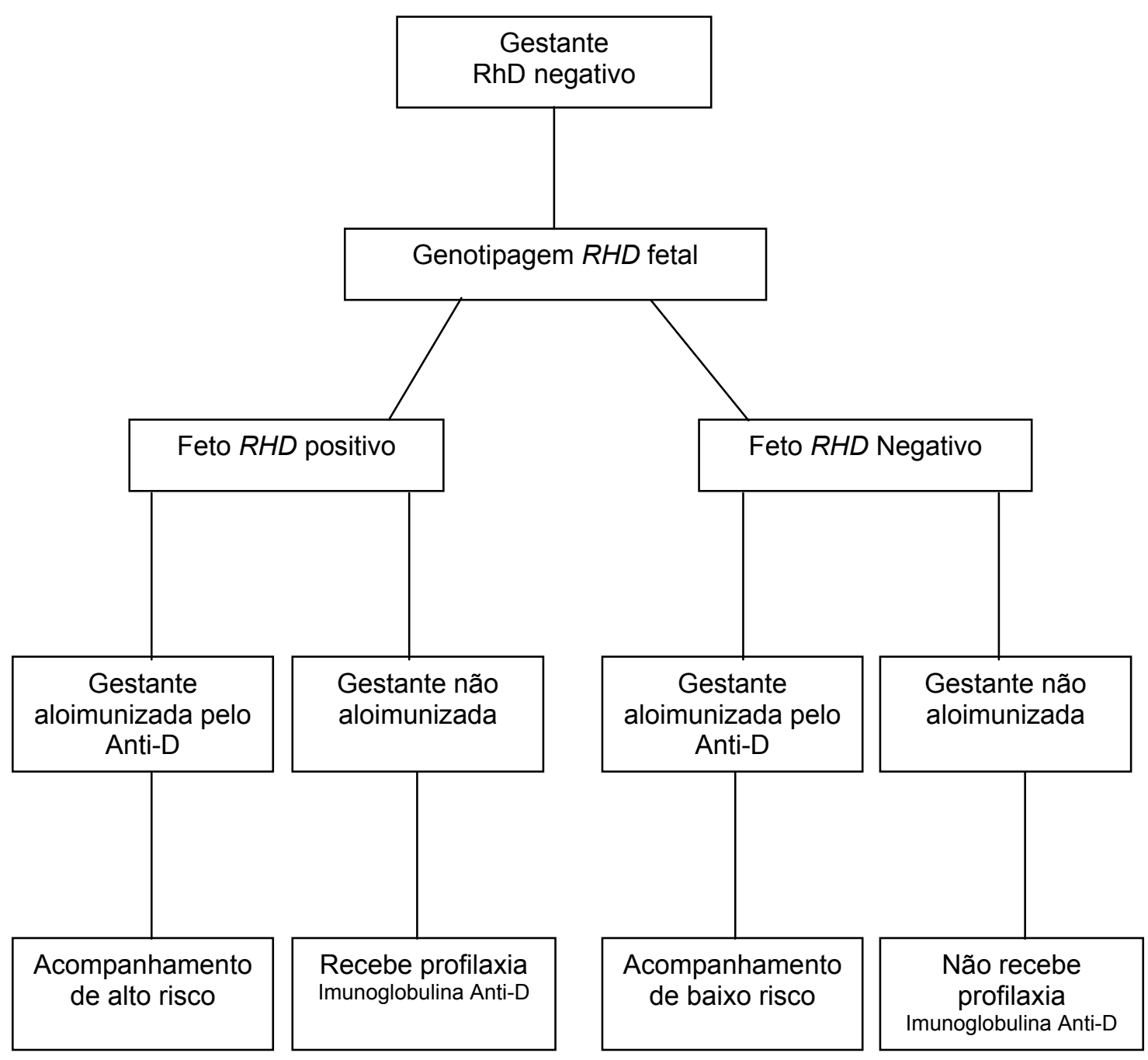

Figura 15 - Fluxograma do teste de genotipagem $R H D$ fetal para o acompanhamento das gestantes $\mathrm{RhD}$ negativo. 
O teste semiautomatizado para determinação do genótipo $R H D$ fetal no plasma materno, demonstrou ser rápido, de fácil execução, alta precisão e reprodutível, com acurácia de $100 \%$.

O equipamento de extração automatizado MagNa Pure Compact (Roche) utilizando o Kit Large Volume foi padronizado, avaliado e aprovado para predizer o genótipo $R H D$ fetal.

O ensaio do RHD $\Psi$ em PCR em tempo real desenvolvido e testado neste estudo mostrou-se rápido, prático e eficiente quando comparado à metodologia padrão ouro.

A metodologia aplicada no estudo possibilitou identificar, investigar e diferenciar possíveis variantes $R H D$.em nossa população.

O teste semiautomatizado para determinação do genótipo $R H D$ fetal no plasma materno apresenta condições ideais para aplicação na prática clínica, principalmente em serviços terciários de saúde pública, onde é possível realizar o teste em larga escala.

Por fim, nosso foco principal é a VIDA, e idealizamos determinar o genótipo $R H D$ fetal para todas as gestantes $\mathrm{RhD}$ negativo, auxiliando diretamente os obstetras na conduta do pré-natal, pois vislumbramos, um dia, poder erradicar a DHPN. 


\section{ANEXO 1 - Aprovação da Comissão de Ética para Análise de Projetos de Pesquisa - CAPPesq - Hospital das Clínicas da Faculdade de Medicina da Universidade de São Paulo}

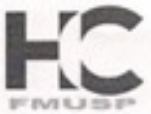

$\mathrm{N}^{\circ}$ Protocolo: $0575 / 11$

Título: ACURÁCIA DO TESTE MOLECULAR DE DETERMINAÇĀO DO RHD FETAL PELA ANÁLISE DO SANGUE MATERNO

Pesquisador Responsável: Adolfo Liao

Pesquisador Executante: Karen Nogueira Chinoca

Co-autores: José Eduardo Levi, Eduardo JensDalton Chamone, Maria de Lourdes Brizot, Marcelo Zugaib

Finalidade Acadêmica: Mestrado

Departamento: OBSTETRICIA E GINECOLOGIA

A Comissão de Ética para Análise de Projetos de Pesquisa CAPPesa da Diretoria Clínica do Hospital das Clínicas da Faculdade de Medicina da Universidade de Sāo Paulo. APROVOU / TOMOU CIÊNCIA na sessăo datada de 19/10/2011, o protocolo acima.

A CAPPesq em obediência à Resolução CNS 196/96, solicita ao pesquisador (a) s elaboraçāo de relatório parcial e final.

No caso de relatório parcial é necessário informar o tempo previsto para a conclusăo do protocolo e breve resumo dos resultados obtidos.

CAPPesq. 21 de Outubro de 2011

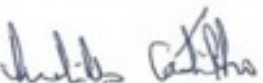

PROF. DR. EUCLIDES AYRES DE CASTILHO

Coordenador

Comissāo de Ética para Análise de

Projetos de Pesquisa - CAPPesq 
ANEXO 2 - Termo de Consentimento Livre e Esclarecido

HOSPITAL DAS CLÍNICAS DA FACULDADE DE MEDICINA DA UNIVERSIDADE DE SÃO PAULO-HCFMUSP

TERMO DE CONSENTIMENTO LIVRE E ESCLARECIDO

DADOS DE IDENTIFICAÇÃO DO SUJEITO DA PESQUISA OU RESPONSÁVEL LEGAL

1.NOME:

DOCUMENTO DE IDENTIDADE N ${ }^{\circ}$ : SEXO : $M \square F$

DATA NASCIMENTO:

ENDEREÇO.

BAIRRO:

$. / \ldots \ldots . . . . . . .$.

CEP:. .TELEFONE:DDD (.....).

... APTO:

CIDADE

2.RESPONSÁVEL LEGAL

NATUREZA (grau de parentesco, tutor, curador etc.)

DOCUMENTO DE IDENTIDADE :

SEXO: $M \square F \square$

DATA NASCIMENTO.: .........

ENDEREÇO: $\mathrm{N}^{\mathrm{O}}$ APTO:

BAIRRO: CIDADE:

CEP: TELEFONE:DDD(...).

\section{DADOS SOBRE A PESQUISA}

1. TÍtULLO DO PROTOCOLO DE PESQUISA: Acurácia do teste molecular de determinação do $R H D$ fetal pela análise do sangue materno.

2. PESQUISADOR : Dr. Adolfo Liao

CARGO/FUNÇÃO: Professor-Associado, Departamento de Obstetrícia e Ginecologia, Faculdade de Medicina USP

INSCRIÇÃO CONSELHO REGIONAL Nº 84.880

UNIDADE DO HCFMUSP: Instituto Central, Hospital das Clínicas FMUSP

3. AVALIAÇÃO DO RISCO DA PESQUISA:

$\begin{array}{ll}\text { RISCO MÍNIMO x } & \text { RISCO MÉDIO } \\ \text { RISCO BAIXO } \square & \text { RISCO MAIOR }\end{array}$

4.DURAÇÃO DA PESQUISA : 24 meses 


\section{HOSPITAL DAS CLÍNICAS DA FACULDADE DE MEDICINA DA UNIVERSIDADE DE SÃO PAULO-HCFMUSP}

1- Estas informações estão sendo fornecidas para sua participação voluntária neste estudo. O objetivo deste estudo é descobrir o tipo sanguíneo do seu bebê antes do nascimento através de uma amostra do seu sangue. Os resultados deste estudo poderão ajudar no acompanhamento pré-natal de gestantes com o tipo de sangue "negativo", como o seu, para a prevenção de uma doença grave em que o sangue da mãe causa destruição das células vermelhas do sangue do bebê.

2- Caso você aceite participar, serão coletados $10 \mathrm{ml}$ de seu sangue (quantidade semelhante ao que se colhe de rotina durante o pré-natal) os quais serão distribuídos em 2 tubos: um para confirmar o seu tipo sanguíneo $A B O / R h$, e outro para estudo do tipo sanguíneo do bebê através da pesquisa de material genético presente em pequena quantidade no seu sangue. Essa coleta pode produzir dor e aparecimento de "roxos" no local da picada como em qualquer coleta de sangue de rotina. O sangue será coletado com agulhas e seringas descartáveis e com o uso de luvas descartáveis. No momento do parto, será coletado 1 tubo contendo aproximadamente $4 \mathrm{ml}$ de sangue do cordão umbilical do seu bebê para confirmação do tipo sanguíneo $\mathrm{ABO} / \mathrm{Rh}$. Este exame já faz parte da rotina neonatal. Caso realize o parto em outro hospital, você deverá se comprometer a trazer seu bebê até 1 (hum) mês de vida para coletar 1 tubo $(4 \mathrm{ml})$ de sangue para a confirmação da tipagem sanguínea.

3- DESCONFORTO E RISCOS ESPERADOS: O desconforto e o risco esperados com sua participação serão mínimos, sendo os mesmos da coleta de sangue para exames.

4- BENEFICIOS QUE PODERÃO SER OBTIDOS COM A PARTICIPAÇÃO NO ESTUDO: Você não terá nenhum beneficio direto pela participação no estudo. Trata-se de um estudo experimental que visa a aplicação do teste de genotipagem RhD fetal através do plasma materno na prática clínica. Sua participação contribuirá para melhorar a identificação do tipo sanguíneo do bebê e consequentemente um tratamento mais eficaz para a doença hemolítica do recém-nascido.

5- Em qualquer etapa do estudo, você terá acesso aos profissionais responsáveis pela pesquisa para esclarecimento de eventuais dúvidas. O principal investigador é o Dr. Adolfo Liao que pode ser encontrado de segunda a sexta, 08 às $12 \mathrm{~h}$, na Clínica Obstétrica, $10^{\circ}$ andar Instituto Central, Av. Dr. Eneas de carvalho Aguiar, 255 Cerqueira Cesar Telefone 1130696209.

Se você tiver alguma consideração ou dúvida sobre a ética da pesquisa, entre em contato com o Comitê de Ética em Pesquisa (CEP) - Rua Ovídio Pires de Campos, $225-5^{\circ}$ andar - tel: 3069-6442 ramais 16, 17, 18 ou 20, FAX: 3069-6442 ramal 26 - E-mail: cappesq@hcnet.usp.br

6- É garantido a você a liberdade da retirar este consentimento a qualquer momento e deixar de participar do estudo, sem qualquer prejuízo à continuidade de seu atendimento nesta Instituição.

7- As informações obtidas com o estudo serão analisadas em conjunto com outras gestantes participantes. Em nenhuma circunstância será divulgada a identificação de qualquer uma das gestantes participantes do estudo.

8- Não haverá despesas pessoais para a participante em qualquer fase do estudo, incluindo exames e consultas. Aquelas gestantes que realizarem o parto em outro 
hospital deverão se comprometer a retornar para a coleta do RN, e receberão um reembolso dos gastos com transporte no valor de $\mathrm{R} \$ 20,00$ (Vinte Reais).

9- O pesquisador se compromete a utilizar o material coletado para esta pesquisa ou pesquisas relacionadas à aloimunização na gestação.

Acredito ter sido suficientemente esclarecida a respeito das informações que li ou que foram lidas para mim, descrevendo o estudo.

"Determinação do genótipo RHD fetal no plasma materno: acurácia do teste semiautomatizado".

Eu discuti com o Dr. Adolfo Liao sobre a minha decisão em participar deste estudo. Ficaram claros para mim quais são os propósitos do estudo, os procedimentos a serem realizados, seus desconfortos e riscos, as garantias de confidencialidade e de esclarecimentos permanentes. Ficou claro também que minha participação é isenta de despesas e que tenho garantia do acesso a tratamento hospitalar quando necessário. Concordo voluntariamente em participar deste estudo e poderei retirar o meu consentimento a qualquer momento, antes ou durante o mesmo, sem penalidades ou prejuízo ou perda de qualquer benefício que eu possa ter adquirido, ou no meu atendimento neste Serviço.

Assinatura do paciente/representantelegal

Assinatura da testemunha
Data

Data

11

para casos de pacientes menores de 18 anos, analfabetos, semianalfabetos ou portadores de deficiência auditiva ou visual.

\section{(Somente para o responsável do projeto)}

Declaro que obtive de forma apropriada e voluntária o Consentimento Livre e Esclarecido deste paciente ou representante legal para a participação neste estudo. 


\section{ANEXO 3 - Ficha de Identificação \\ Determinação do genótipo RHD fetal no plasma materno: acurácia do teste semiautomatizado}

FICHA DE IDENTIFICAÇÃO

Nome:

Registro Hospitalar:

Etnia: ( ) Branco ( ) Negro ( ) Pardo ( )Asiático

Data de Nascimento: 1

Idade: anos

Endereço:

Bairro: Cidade: Estado:

Telefone Residencial: Celular:( )

Telefone para recado: $(\quad$ )

Nome do marido/Pai da criança atual:

Doenças nesta gestação: Medicações:

Gesta: Para: Ab: DUM:

Data do primeiro exame USG: Idade Gestacional:

Data de coleta da amostra: _______ Idade Gestacional: semanas

Tipagem Sanguínea (gestante):

Aloimunizada: Anticorpo: Título:

Tipagem Sanguínea filho(a)

Já recebeu transfusão de sangue: ( ) Não Sim ( ) Quando: _l__ Responsável pela coleta da amostra: 


\section{ANEXO 4 -}

Protocolo de reação duplex $R H D$ (éxon 5 e 7).

\begin{tabular}{|c|c|c|c|}
\hline Reagente: (Duplex Éxons 5 e 7) & por tubo (uL) & Fabricante & [FINAL] \\
\hline $\begin{array}{l}\text { 2x TaqMan Universal PCR master } \\
\text { mix com UNG* }\end{array}$ & 12 & $\begin{array}{c}\text { Applied } \\
\text { BioSystems }{ }^{\circledR}\end{array}$ & $1 X$ \\
\hline \multicolumn{4}{|l|}{ Éxon 7} \\
\hline Primer: 940F 10uM & 1,5 & $\begin{array}{c}\text { Applied } \\
\text { BioSystems }{ }^{\circledR} \\
\text { Applied }\end{array}$ & $600 \mathrm{nM}$ \\
\hline Primer: 1064R 10uM & 1,5 & $\begin{array}{l}\text { BioSystems }{ }^{\circledR} \\
\text { Applied }\end{array}$ & $600 \mathrm{nM}$ \\
\hline Sonda: 968T 5uM (FAM/TAM) & 0,5 & BioSystems ${ }^{\circledR}$ & 100nM \\
\hline \multicolumn{4}{|l|}{ Éxon 5} \\
\hline Primer: ex5F 10uM & 1,5 & $\begin{array}{c}\text { Applied } \\
\text { BioSystems } ® \\
\text { Applied }\end{array}$ & 600nM \\
\hline Primer: ex5R 10uM & 1,5 & $\begin{array}{l}\text { BioSystems }{ }^{\circledR} \\
\text { Applied }\end{array}$ & $600 \mathrm{nM}$ \\
\hline Sonda: ex5T 5uM (VIC/TAM) & 0,5 & BioSystems ${ }^{\circledR}$ & 100nM \\
\hline Total & 19 & & \\
\hline DNA & 6 & & \\
\hline Volume final & 25 & & \\
\hline
\end{tabular}

*Taqman Universal Master mix com UNG é composto dos reagentes necessários para a realização da atividade 5'nucleásica, como enzima AMpliTaq Gold, Enzima AmpErase UNG e dNTPs com dUTP.

Protocolo de reação do CCR5 (controle de DNA total).

\begin{tabular}{|c|c|c|c|}
\hline Reagente: (CCR5) & por tubo (uL) & Fabricante & [FINAL] \\
\hline $\begin{array}{l}\text { 2x TaqMan Universal PCR master } \\
\text { mix com UNG }\end{array}$ & 12,5 & $\begin{array}{c}\text { Applied } \\
\text { BioSystems }{ }^{\circledR}\end{array}$ & $1 \mathrm{X}$ \\
\hline \multicolumn{4}{|l|}{$\underline{\text { CCR5 }}$} \\
\hline Primer: CCR5F 5uM & 1,5 & $\begin{array}{c}\text { Applied } \\
\text { BioSystems }{ }^{\circledR} \\
\text { Applied }\end{array}$ & 300nM \\
\hline Primer: CCR5R 5uM & 1,5 & $\begin{array}{l}\text { BioSystems }{ }^{\circledR} \\
\quad \text { Applied }\end{array}$ & 300nM \\
\hline Sonda: CCR5 5uM (FAM) & 0,5 & BioSystems $®$ & 100nM \\
\hline Água & 3 & & \\
\hline Total & 19 & & \\
\hline DNA & 6 & & \\
\hline Volume final & 25 & & \\
\hline
\end{tabular}


Condições de temperatura aplicados na PCR em tempo real para o protocolo duplex (éxon 5 e 7) e CCR5.

\begin{tabular}{ll}
\hline Temperatura & Tempo \\
\hline Incubação inicial: $50 \circ \mathrm{C}$ & 2 minutos \\
Desnaturação: $950 \mathrm{C}$ & 10 minutos \\
Desnaturação:95oC & 15 segundos \\
Anelamento: $60 \circ \mathrm{oC}$ & 1 minuto \\
Quantidade de ciclos da PCR: 50 & Aproximadamente:1 hora e 40 minutos \\
\hline
\end{tabular}

Protocolo de reação do Pseudogene $R H D \Psi$ na PCR em tempo real.

\begin{tabular}{|c|c|c|c|}
\hline Reagente: (Pseudogene RHD $\Psi$ ) & por tubo (uL) & Fabricante & [FINAL] \\
\hline $\begin{array}{l}\text { 2x TaqMan Universal PCR master } \\
\text { mix com UNG }\end{array}$ & 12,5 & $\begin{array}{c}\text { Applied } \\
\text { BioSystems }{ }^{\circledR}\end{array}$ & $1 \mathrm{X}$ \\
\hline \multicolumn{4}{|l|}{ Pseudogene RHD $\Psi$} \\
\hline Primer: Pseudo F 10uM & 2,5 & $\begin{array}{c}\text { Applied } \\
\text { BioSystems }{ }^{\circledR} \\
\text { Applied }\end{array}$ & 1000nM \\
\hline Primer: Pseudo-R 10uM & 2,5 & $\begin{array}{c}\text { BioSystems }{ }^{\circledR} \\
\text { Applied }\end{array}$ & $1000 \mathrm{nM}$ \\
\hline Sonda: Pseudo 10 uM & 1 & BioSystems $®$ & 400nM \\
\hline Total & 18,5 & & \\
\hline DNA* $^{*}$ & 6,5 & & \\
\hline Volume final & 25 & & \\
\hline
\end{tabular}

Condições de temperatura aplicados na PCR em tempo real.

\begin{tabular}{ll}
\hline Temperatura & Tempo \\
\hline Incubação inicial: $50 \circ \mathrm{C}$ & 2 minutos \\
Desnaturação: $95 \circ \mathrm{C}$ & 10 minutos \\
Desnaturação:95oC & 15 segundos \\
Anelamento: $60 \circ \mathrm{C}$ & 1 minuto \\
Quantidade de ciclos da PCR: 50 & Aproximadamente:1 hora e 40 minutos \\
\hline
\end{tabular}


Protocolo de reação do Multiplex RHD (Intron 4/Éxon 7), Pseudogene, $\mathrm{RH}^{\star} \mathrm{C} / \mathrm{c}$ na PCR convencional.

\begin{tabular}{|c|c|c|c|}
\hline \multicolumn{2}{|c|}{ RHD/Pseudogene/RHCc por tubo (uL) } & \multirow{2}{*}{ Lote } & \multirow{2}{*}{$\begin{array}{c}\text { Fabricante } \\
-\end{array}$} \\
\hline $\mathrm{H}_{2} \mathrm{Odd}$ & 9,5 & & \\
\hline Tampão(15Mm $\mathrm{MgCl}_{2}$ ) & 3 & ZDMB1e & Invitrogen \\
\hline $\mathrm{MgCl}_{2}$ & 1 & ZDMB1b & Invitrogen \\
\hline $\begin{array}{l}\text { DNTPs mix }(10 \mathrm{mM}) \\
\text { Pool In3for2/E4insert }\end{array}$ & 1 & 1253500 & $\begin{array}{l}\text { Invitrogen } \\
\text { MWG }\end{array}$ \\
\hline rev(100ng) Pseudo & 4 & $51704447200 / 51704448200$ & $\begin{array}{l}\text { Biotech AG } \\
\quad \text { MWG }\end{array}$ \\
\hline Pool c for/ c rev (100ng) & 1 & $51704451200 / 51704455200$ & Biotech AG \\
\hline Taq Platinum & 0,5 & ZDSB1C & Invitrogen \\
\hline Total & 20 & & \\
\hline Extração DNA & 5 & & \\
\hline
\end{tabular}

Condições de temperatura aplicados na reação de PCR convencional realizada em termociclador.

\begin{tabular}{ll}
\hline Temperatura & Tempo \\
\hline Desnaturação: $95^{\circ} \mathrm{C}$ & 15 minutos \\
Desnaturação: $94^{\circ} \mathrm{C}$ & 1 minuto \\
Anelamento: $65,5^{\circ} \mathrm{C}$ & 1 minuto \\
Extensão: $72^{\circ} \mathrm{C}$ & 3 minutos e 30 segundos \\
Extensão: $72^{\circ} \mathrm{C}$ & 10 minutos \\
Quantidade de ciclos:30 & \\
\hline
\end{tabular}


Protocolo de reação do Multiplex $R H D$ (éxons $3,4,5,6,7$ e 9) na PCR convencional aplicado no estudo.

\begin{tabular}{|c|c|c|c|}
\hline RHD Parcial & $\begin{array}{c}\text { por tubo } \\
\text { (uL) }\end{array}$ & Lote & Fabricante \\
\hline $\mathrm{H}_{2} \mathrm{Odd}$ & 15,5 & - & - \\
\hline Tampão(15Mm $\left.\mathrm{MgCl}_{2}\right)$ & 3 & ZDMB1e & Invitrogen \\
\hline $\mathrm{MgCl}_{2}$ & 1 & ZDMB1b & Invitrogen \\
\hline $\begin{array}{l}\text { DNTPs mix (10mM) } \\
\text { Pool R364 /R474M (100ng) }\end{array}$ & 1 & 1253500 & $\begin{array}{l}\text { Invitrogen } \\
\text { MWG }\end{array}$ \\
\hline $\begin{array}{l}\text { Ex3 } \\
\text { Pool R496 /R621(100ng) }\end{array}$ & 0,6 & 2140231560/151704E02 & $\begin{array}{l}\text { Biotech AG } \\
\quad \text { MWG }\end{array}$ \\
\hline $\begin{array}{l}\text { Ex4 } \\
\text { Pool R648 /Rex5AD2 }\end{array}$ & 0,6 & $2720053768 / 2720053868$ & Biotech AG \\
\hline $\begin{array}{l}\text { (100ng) Ex5 } \\
\text { Pool R973 /R1068 (100ng) }\end{array}$ & 2 & $157281 \mathrm{G} 11 / 157281 \mathrm{G} 10$ & $\begin{array}{l}\text { Invitrogen } \\
\text { MWG }\end{array}$ \\
\hline $\begin{array}{l}\text { Ex7 } \\
\text { Pool Rex9SD2/R1219M }\end{array}$ & 0,6 & $2720054368 / 2720054468$ & Biotech AG \\
\hline $\begin{array}{l}\text { (100ng) Ex9 } \\
\text { R898M / Rex6AD3 (100ng) }\end{array}$ & 1,6 & $157281 \mathrm{G} 12 / 157281 \mathrm{H} 01$ & Invitrogen \\
\hline Ex6 & 0,6 & 162209E03/162209E04 & Invitrogen \\
\hline Taq DNA Platinum & 0,5 & ZDSB1C & Invitrogen \\
\hline $\begin{array}{l}\text { Total } \\
\text { Extração DNA }\end{array}$ & $\begin{array}{c}27 \\
3\end{array}$ & & \\
\hline
\end{tabular}

Condições de temperatura aplicados na reação de PCR convencional realizada em termociclador.

\begin{tabular}{ll}
\hline Temperatura & Tempo \\
\hline Desnaturação: $95^{\circ} \mathrm{C}$ & 5 minutos \\
Desnaturação: $95^{\circ} \mathrm{C}$ & 1 minuto \\
Anelamento: $56^{\circ} \mathrm{C}$ & 1 minuto \\
Extensão: $72^{\circ} \mathrm{C}$ & 45 segundos \\
Extensão: $72^{\circ} \mathrm{C}$ & 5 minutos \\
Quantidade de ciclos:30 &
\end{tabular}




\section{ANEXO 5}

\section{PROTOCOLO PARA EXTRAÇÃO DE DNA - BRAZOL}

1. Pipetar 200 uL (microlitros) da amostra de sangue em um microtubo de $2.0 \mathrm{~mL}$, devidamente identificados. A amostra de sangue deve ser homogeneizada antes de pipetar. Em algumas situações é possível pipetar o buffy coat

2. Adicionar 500 ul de Brazol gelado $\left(4^{\circ} \mathrm{C}\right)$ e agitar no vortex até a amostra adquirir aspecto homogêneo

3. Adicionar 100 ul de cloroformio gelado $\left(4^{\circ} \mathrm{C}\right)$ e misturar no vortex até a amostra adquirir uma coloração "cor de chocolate"

4. Centrifugar por 12 minutos a $10.000 \mathrm{rpm}$ em T.A.

5. Após a centrifugação, retirar o microtubo cuidadosamente da centrífuga e verificar se a solução está dividida em 2 partes

6. Pipetar cuidadosamente a fase superior (SOBRENADANTE) e transferir para tubos de $1,5 \mathrm{~mL}$ identificados corretamente.

7. Adicionar $500 u$ de etanol $100 \%$ gelado (armazenado a $4^{\circ} \mathrm{C}$ ), homogeneizar no vortex e observar a formação de um precipitado. O precipitado é usualmente visualizado em 30 a 60 segundos.

8. Centrifugar por 15 minutos a $10.000 \mathrm{rpm}$ em T.A.

9. Decantar o sobrenadante e adicionar novamente 500ul de etanol $100 \%$ gelado (armazenado a $4^{\circ} \mathrm{C}$ )

10. Centrifugar por 12 minutos a $10.000 \mathrm{rpm}$ em T.A. 
11. Decantar o sobrenadante

12. Remover o etanol residual com pipeta e colocar no banho seco $56^{\circ} \mathrm{C}$ por 10 minutos

13. Adicionar 50uL de água destilada estéril em cada tubo $\left(\mathrm{H}_{2} \mathrm{Odd}\right)$

Importante verificar se não há resíduo de etanol antes de adicionar água destilada estéril para diluir o DNA (resíduos de etanol pode inibir o DNA)

14. Quantificar o DNA genômico utilizando o equipamento NanoDrop1000

15. Armazenar o DNA purificado a $4^{\circ} \mathrm{C}$ ou $-20^{\circ} \mathrm{C}$. 
1. Baiochi E, Nardozza LMM. Aloimunização. Rev Bras Ginecol Obstet. 2009:31(6):311-9.

2. Urbaniak SJ, Greiss MA. RhD haemolytic disease of the fetus and the newborn. Blood Rev. 2000;14(1):44-61.

3. ISBT, Internacional Society of Blood Transfusion [citado 15 jan 2015]. Disponível em: http://www.isbtweb.org/working-parties/red-cellimmunogenetics-and-blood-group-terminology

4. Hartwell EA. Use of Rh immune globulin: ASCP practice parameter. American Society of Clinical Pathologists. Am J Clin Pathol. 1998; 110(3):281-92.

5. Moise KJ. Fetal anemia due to non-Rhesus-D red-cell alloimmunization. Semin Fetal Neonatal Med. 2008;(13):207-14.

6. Nardozza LM, Lobo GR, Moron AF, Camano L, Araujo E Jr, Guimarães Filho HA. Anti-Lewis alloimmunization: report of seven cases. Clin Exp Obstet Gynecol. 2008;35(4):311-2.

7. M de Haas, Thurik FF, Koelewijn JM, van der Schoot CE. Haemolytic disease of the fetus and newborn. Vox Sang. 2015 Aug;109(2):99-113.

8. Chinoca KN, Liao AW, Bianchi JVDS, Francisco RPV, Jens E, Zugaib M. Caracterização imunohematológica de gestantes aloimunizadas da Clínica Obstétrica do Hospital das Clínicas da FMUSP; HEMO Congresso Brasileiro de Hematologia, Hemoterapia e Terapia Celular; 2012; Rio de Janeiro. 
9. Daniels G. Human Blood Groups: Rh and RHAG blood group systems. 3a ed. Bristol: Wiley-Blackwell, 2013.

10. Baiochi E, Camano L, Sass N, Colas OR. Frequências dos grupos sanguíneos e incompatibilidades $A B O$ e RHD em puérperas e seus recém-nascidos. Rev Assoc Med Bras. 2007; 53(1): 44-6.

11. Cruz BR, Chiba AK, Moritz E, Bordin JO. RHD alleles in Brazilian blood donors with weak D or D-negative phenotypes. Transfus Med. 2012 Apr;22(2):84-9.

12. DATASUS. Tecnologia da Informação a Serviço do SUS [citado 13 jun 2015].

http://tabnet.datasus.gov.br/cgi/tabcgi.exe?sinasc/cnv/nvuf.def.

13. Santos MCP. Uso da imunoglobulina humana em recém-nascidos com anemia hemolítica por Aloimunização Rh (D): ensaio clínico duplo cego, randomizado. [Tese]. Rio de Janeiro: Instituto Nacional de Saúde da Mulher, da Criança e do Adolescente Fernandes Figueira; Fundação Oswaldo Cruz; 2009.

14. Kent J, Farrell AM, Soothill P. Routine administration of Anti-D: the ethical case for offering pregnant women fetal RHD genotyping and a review of policy and practice. BMC Pregnancy Childbirth. 2014;14:87.

15. Crowther $\mathrm{C}$, Middleton $\mathrm{P}$. Anti-D administration after childbirth for preventing Rhesus alloimmunisation. Cochrane Database Syst Rev. 2000;(2):CD000021..

16. Pacheco CAMS. Doença hemolítica perinatal RhD: um problema de saúde pública no Brasil. [Tese]. Rio de Janeiro: Instituto Nacional de Saúde da Mulher, da Criança e do Adolescente Fernandes Figueira; Fundação Oswaldo Cruz; 2013. 
17. Avent ND, Finning KM, Martin PG, Soothill PW. Prenatal determination of fetal blood group status. Vox Sang. 2000;78 Suppl 2:155-62.

18. Wagner FF. 1998. The RhesusBase, Department of Transfusion Medicine,University Hospital, Ulm, Germany. [citado 20 ago 2015]. Disponível em: http://www.uni-ulm.de/ wflegel/RH/RB

19. Machado IN, Castilho L, Pellegrino J, Barini R. Fetal RhD genotyping from maternal plasma in a population with a highly diverse ethnic background. Rev Assoc Med Bras. 2006;52(4):232-5.

20. Rodeck $\mathrm{CH}$, Whittle MJ. Medicina fetal: Fundamentos e prática clínica. Rio de Janeiro: Revinter; 2005.

21. Moise Jr KJ. Management of rhesus alloimmunization in pregnancy. Obstet Gynecol. 2008;112(1):164-76.

22. Lo YM, Hjelm NM, Fidler C, Sargent IL, Murphy MF, Chamberlain PF, et al. Prenatal diagnosis of fetal RhD status by molecular analysis of maternal plasma. N Engl J Med. 1998;339(24):1734-8.

23. Geifman-Holtzman O, Grotegut CA, Gaughan JP. Diagnostic accuracy of noninvasive fetal Rh genotyping from maternal blood--a metaanalysis. Am J Obstet Gynecol. 2006;195(4):1163-73.

24. Clausen FB, Damkjær MB, Dziegiel $\mathrm{MH}$. Noninvasive fetal RhD genotyping. Transfus Apher Sci. 2014;50(2):154-62.

25. El Messaoudi S, Rolet F, Mouliere F, Thierry AR. Circulating cell free DNA: Preanalytical considerations. Clin Chim Acta. 2013;424:222-30. 
26. Clausen FB, Jakobsen TR, Rieneck K, Krog GR, Nielsen LK, Tabor A, Dziegiel $\mathrm{MH}$. Pre-analytical conditions in non-invasive prenatal testing of cell-free fetal RHD. PLoS One. 2013;8(10):276990.

27. Finning KM, Martin PG, Soothill PW, Avent ND. Prediction of fetal D status from maternal plasma: introduction of a new noninvasive fetal RHD genotyping service. Transfusion. 2002;42(8):1079-85.

28. Chinen PA. Determinação do genótipo RHD fetal, no sangue materno, pela técnica da reação em cadeia da polimerase em tempo real. [Tese]. São Paulo: Escola Paulista de Medicina; Universidade Federal de São Paulo, 2008.

29. Teitelbaum L, Metcalfe A, Clarke G, Parboosingh JS, Wilson RD, Johnson JM. Costs and benefits of non-invasive fetal RhD determination. Ultrasound Obstet Gynecol. 2015;45(1):84-8.

30. M de Haas M, Van der Ploeg CPB, Scheffer PG, Verlinden DA, Hirschberg H, Abbink F, Van der Schoot CE. A nation-wide fetal RHD screening programme for targeted antenatal and postnatal anti-D. ISBT Science Series. 2012;7:164-167.

31. Clausen FB, Christiansen $M$, Steffensen $R$, Jørgensen $S$, Nielsen $C$, Jakobsen MA, et al. Report of the first nationally implemented clinical routine screening for fetal $R H D$ in D-pregnant women to ascertain the requirement for antenatal RhD prophylaxis. Transfusion. 2012;52(4): 752-8.

32. Damkjaer MB, Perslev A, Clausen FB, Dziegiel MH,Jorgensen FS. Study of compliance with a new, targeted antenatal Dimmunization prevention. programme in Denmark. Vox Sang. 2012 Aug;103(2):145-9. 
33. Soothill P, Finning K, Latham T, Wreford-Bush T, Ford J, Daniels G. Use of cffDNA to avoid administration of anti-D to pregnant women when the fetus is RhD-negative: implementation in the NHS. BJOG. 2014 Aug 21.

34. Wikman AT, Tiblad E, Karlsson A, Olsson ML, Westgren M, Reilly M. Noninvasive single-ÉXON fetal RHD determination in a routine screening program in early pregnancy. Obstet Gynecol. 2012;120(2 Pt 1):227-34.

35. Chérif-Zahar B, Mattei M G, Le Van Kim C, Bailly P, Cartron J P. Localization of the human $\mathrm{Rh}$ blood group gene structure to chromosome region $1 \mathrm{p} 34.3-1 \mathrm{p} 36.1$ by in situ hybridization. Human Genetics. 1991;86:398-400.

36. Reid ME, Francis CL, Olsson ML. The blood group antigen: Rh blood group system. 3a ed. New York: Academic Press; 2012.

37. Wagner FF, Flegel WA. RHD gene deletion occurred in the Rhesus box. Blood. 2000;95(12):3662-8.

38. Wagner FF, Flegel WA. Review: the molecular basis of the Rh blood group phenotypes. Immunohematology. 2004;20(1):23-36.

39. Daniels G, Poole J, de Silva M, Callaghan T, MacLennan S, Smith N. The clinical significance of blood group antibodies. Transfus Med. 2002; 12(5):287-95.

40. Tilley L, Green C, Poole J, Gaskell A, Ridgwell K, Burton NM, et al. A new blood group system, RHAG: three antigens resulting from amino acid substitutions in the Rh-associated glycoprotein. Vox Sang. 2010; $98(2): 151-9$. 
41. Cartron JP. RH blood group system and molecular basis of Rhdeficiency. Baillieres Best Pract Res Clin Haematol. 1999;12(4):655-89.

42. Flegel WA. Molecular genetics and clinical applications for $\mathrm{RH}$. Transfus Apher Sci. 2011;44(1):81-91.

43. Daniels G, Finning K, Martin P, Summers J. Fetal RhD genotyping: a more efficient use of anti-D immunoglobulin. Transfus Clin Biol. 2007; 14(6):568-71.

44. Chou ST, Westhoff CM. Molecular biology of the Rh system: clinical considerations for transfusion in sickle cell disease. Hematology Am Soc Hematol Educ Program. 2009:178-84.

45. Singleton BK, Green CA, Avent ND, Martin PG, Smart E, Daka A, et al. The presence of an RHD pseudogene containing a 37 base pair duplication and a nonsense mutation in africans with the Rh D-negative blood group phenotype. Blood. 2000;95(1):12-8.

46. Rodrigues A, Rios M, Pellegrino Jr J, Costa FF, Castilho L. Presence of RHD pseudogene and the hybrid RHD-CE-Ds gene in Brazilians with the Dnegative phenotype. Braz J Med Biol Res. 2002;35:767-773.

47. Mota M, Dezan M, Valgueiro MC, Sakashita AM, Kutner JM, Castilho L. RHD allelic identification among D-Brazilian blood donors as a routine test using pools of DNA. J Clin Lab Anal. 2012;26(2):104-8.

48. Wagner FF, Frohmajer A, Flegel WA. RHD positive haplotypes in D negative Europeans. BMC Genetics. 2001;21:10. 
49. Minon JM, Senterre JM, Schaaps JP, Foldart JM. An unusual falsepositive fetal RHD typing result using DNA derived from maternal plasma from solid organ transplant recipient. Transfusion 2006; 46:1454-1455.

50. Mota M. Identificação do gene RHD em doadores voluntários de sangue fenotipados como RHD negativo utilizando pools de DNA. [Tese]. Campinas: Universidade Estadual de Campinas; 2012.

51. Müller TH, Wagner FF, Trockenbacher A, Eicher NI, Flegel W, Schönitzer D, Schunter F, Gassner C. PCR screening for common weak $D$ types shows different distributions in three Central Europeans populations. Transfusion. 2001;41:45-52.

52. Westhoff CM. Rh complexities: serology and DNA genotyping. Transfusion. 2007;47(1 Suppl):17S-22S.

53. Schmidt LC. Genotipagem RHD fetal no plasma materno como ferramenta não invasiva na predição do risco da doença hemolítica perinatal em gestantes RhD negativo [Dissertação]. Belo Horizonte: Universidade Federal de Minas Gerais; 2010.

54. Denomme GA, Dake LR, Vilensky D, Ramyar L, Judd WJ. Rh discrepancies caused by variable reactivity of partial and weak $D$ types with different serologic techniques. Transfusion. 2008;48(3):473-8.

55. Litton C, Stone J, Eddleman K, Lee MJ. Noninvasive prenatal diagnosis: past, present, and future. Mt Sinai J Med. 2009;76(6):521-8.

56. Ipursky A, Hull A, White FD, Israels LG. Foetal erythrocytes in the maternal circulation. Lancet. 1959;1(7070):451-2. 
57. Bianchi DW. Current knowledge about fetal blood cells in the maternal circulation. J Perinat Med. 1998;26(3):175-85.

58. Chen XQ, Stroun M, Magnenat JL, Nicod LP, Kurt AM, Lyautey J, et al. Microsatellite alterations in plasma DNA of small cell lung cancer patients. Nat Med. 1996;2(9):1033-5.

59. Lo YM, Corbetta N, Chamberlain PF, Rai V, Sargent IL, Redman CW, et al. Presence of fetal DNA in maternal plasma and serum. Lancet. 1997;350(9076):485-7.

60. Avent ND, Madgett TE, Maddocks DG, Soothill PW. Cell-free fetal DNA in the maternal serum and plasma: current and evolving applications. Curr Opin Obstet Gynecol. 2009;21(2):175-9.

61. Alberry M, Maddocks D, Jones M, Abdel Hadi M, Abdel-Fattah S, Avent $\mathrm{N}$, et al. Free fetal DNA in maternal plasma in anembryonic pregnancies: confirmation that the origin is the trophoblast. Prenat Diagn. 2007;27(5):415-8.

62. Chan KC, Zhang J, Hui AB, Wong N, Lau TK, Leung TN, et al. Size distributions of maternal and fetal DNA in maternal plasma. Clin Chem. 2004;50(1):88-92.

63. Lo YM, Chan KC, Sun H, Chen EZ, Jiang P, Lun FM, et al. Maternal plasma DNA sequencing reveals the genome-wide genetic and mutational profile of the fetus. Sci Transl Med. 2010;2(61):61-91.

64. Galbiati S, Smid M, Gambini D, Ferrari A, Restagno G, Viora E, et al. Fetal DNA detection in maternal plasma throughout gestation. Hum Genet. 2005;117(2-3):243-8. 
65. Zhou L, Thorson JA, Nugent C, Davenport RD, Butch SH, Judd WJ. Noninvasive prenatal RHD genotyping by real-time polymerase chain reaction using plasma from D-negative pregnant women. Am J Obstet Gynecol. 2005;193(6):1966-71.

66. Wilson RD. Amniocentesis and chorionic villus sampling. Curr Opin Obstet Gynecol. 2000;12(2):81-6.

67. Gahan PB. Circulating nucleic acids in plasma and serum: applications in diagnostic techniques for noninvasive prenatal diagnosis. Int $\mathrm{J}$ Womens Health. 2013;5:177-86.

68. Hahn S, Zhong XY, Holzgreve W. Recent progress in non-invasive prenatal diagnosis. Semin Fetal Neonatal Med. 2008;13(2):57-62.

69. Nelson M, Eagle C, Langshaw M, Popp H, Kronenberg H. Genotyping fetal DNA by non-invasive means: extraction from maternal plasma. Vox Sang. 2001;80(2):112-6.

70. Daniels G, van der Schoot CE, Gassner C, Olsson ML. Report of the Third International Workshop on Molecular Blood Group Genotyping. Vox Sang. 2009;96(4):337-43.

71. Maddocks DG, Alberry MS, Attilakos G, Madgett TE, Choi K, Soothill PW, Avent ND. The SAFE project: towards non-invasive prenatal diagnosis. Biochem Soc Trans. 2009;37(Pt 2):460-5.

72. Avent ND. RHD genotyping from maternal plasma: guidelines and technical challenges. Methods Mol Biol. 2008;444:185-201.

73. Brojer E, Zupanska B, Guz K, Orziñska A, Kaliñska A. Noninvasive determination of fetal RHD status by examination of cell-free DNA in maternal plasma. Transfusion. 2005;45(9):1473-80. 
74. Barrett AN, Zimmermann BG, Wang D, Holloway A, Chitty LS. Implementing prenatal diagnosis based on cell-free fetal DNA: accurate identification of factors affecting fetal DNA yield. PLoS One. 2011;6(10): e25202.

75. Finning $\mathrm{K}$, Martin $\mathrm{P}$, Daniels $\mathrm{G}$. A clinical service in the UK to predict fetal Rh (Rhesus) D blood group using free fetal DNA in maternal plasma. Ann N Y Acad Sci. 2004;1022:119-23.

76. Gautier E, Benachi A, Giovangrandi Y, Ernault P, Olivi M, Gaillon T, et al. Fetal RhD genotyping by maternal serum analysis: a two-year experience. Am J Obstet Gynecol. 2005;192(3):666-9.

77. Finning K, Martin P, Summers J, Massey E, Poole G, Daniels G. Effect of high throughput RHD typing of fetal DNA in maternal plasma on use of anti-RhD immunoglobulin in RhD negative pregnant women: prospective feasibility study. BMJ. 2008;336(7648):816-8.

78. Fernando MR, Chen K, Norton S, Krzyzanowski G, Bourne D, Ryan WL, et al. A new methodology to preserve the original proportion and integrity of cell-free fetal DNA in maternal plasma during sample processing and storage. Prenat Diagn. 2010;30:418-24.

79. Wong D, Moturi S, Angkachatchai V, Mueller R, DeSantis G, van den Boom D, et al. Optimizing blood collection, transport and storage conditions for cell free DNA increases access to prenatal testing. Clin Biochem. 2013;46:1099-104.

80. Clausen FB, Krog GR, Rieneck K, Dziegiel MH. Improvement in fetal DNA extraction from maternal plasma. Evaluation of the NucliSens Magnetic Extraction system and the QIAamp DSP Virus Kit in comparison with the QIAamp DNA Blood Mini Kit. Prenat Diagn. 2007 Jan;27(1):6-10. 
81. Repiská G, Sedláčková $T$, Szemes $T$, Celec $P$, Minárik G. Selection of the optimal manual method of cell free fetal DNA isolation from maternal plasma. Clin Chem Lab Med. 2013 Jun;51(6):1185-9.

82. Muller SP, Bartels I, Stein W, Emons G, Gutensohn K, Legler TJ. Cellfree fetal DNA in specimen from pregnant women is stable up to 5 days. Prenat Diagn. 2011;31:1300-4.

83. Legler TJ, Liu Z, Mavrou A, Finning K, Hromadnikova I, Galbiati S, Meaney C, Hultén MA, Crea F, Olsson ML, Maddocks DG, Huang D, Fisher SA, Sprenger-Haussels M, Soussan AA, van der Schoot CE.. Workshop report on the extraction of foetal DNA from maternal plasma. Prenat Diagn. 2007;27(9):824-9.

84. Nascimento S, Suarez ER, Pinhal MPS. Tecnologia de PCR e RT-PCR em tempo real e suas aplicações na área médica. RBM Rev Bras Med. 2010:67:7-19.

85. Applied Biosystems StepOne ${ }^{\mathrm{TM}}$ and StepOnePlus ${ }^{\mathrm{TM}}$ Real-Time PCR Systems Genotyping Experiments. In: Biosystems A, editor. Applied Biosystems StepOne $^{\mathrm{TM}}$ and StepOnePlus ${ }^{\mathrm{TM}}{ }^{\mathrm{M}}$ Real-Time PCR Systems Genotyping Experiments; 2010. p. 1-127.

86. Daniels G, Finning K, Martin P, Massey E. Noninvasive prenatal diagnosis of fetal blood group phenotypes: current practice and future prospects. Prenat Diagn. 2009;29(2):101-7.

87. Kolialexi A, Tounta G, Mavrou A. Noninvasive fetal RhD genotyping from maternal blood. Expert Rev Mol Diagn. 2010;10(3):285-96.

88. Fass $B$, Beuling $E A$, Chiristianes $G C$, von dem Borne $A E$, van der Shoot CE. Detection of fetal RHD-specific sequences in maternal plasma. Lancet. 1998;352(9135):1196. 
89. Minon JM, Schaaps JP, Retz MC, Dricot JF, Foidart JM, Senterre JM. [Prenatal determination of fetal RHD in maternal plasma: two-years experience of routine clinical use]. J Gynecol Obstet Biol Reprod (Paris). 2005;34(5):448-53.

90. Müller SP, Bartels I, Stein W, Emons G, Gutensohn K, Köhler M, et al. The determination of the fetal $D$ status from maternal plasma for decision making on $\mathrm{Rh}$ prophylaxis is feasible. Transfusion. 2008; 48(11):2292-301.

91. Chan KC, Ding C, Gerovassili A, Yeung SW, Chiu RW, Leung TN, et al. Hypermethylated RASSF1A in maternal plasma: A universal fetal DNA marker that improves the reliability of noninvasive prenatal diagnosis. Clin Chem. 2006;52(12):2211-8.

92. Grootkerk-Tax MG, Soussan AA, de Haas M, Maaskant-van Wijk PA, van der Schoot CE. Evaluation of prenatal RHD typing strategies on cell-free fetal DNA from maternal plasma. Transfusion. 2006;46(12): 2142-8.

93. Chitty LS, Finning K, Wade A, Soothill P, Martin B, Oxenford K, et al. Diagnostic accuracy of routine antenatal determination of fetal RHD status across gestation: population based cohort study. BMJ. 2014;349: g5243.

94. Zhang J, Fidler C, Murphy MF, Chamberlain PF, Sargent IL, Redman $\mathrm{CW}$, et al. Determination of fetal RhD status by maternal plasma DNA analysis. Ann N Y Acad Sci. 2000;906:153-5.

95. Legler TJ, Lynen R, Maas JH, Pindur G, Kulenkampff D, Suren A, et al. Prediction of fetal Rh D and Rh CcEe phenotype from maternal plasma with real-time polymerase chain reaction. Transfus Apher Sci. 2002; 27(3):217-23. 
96. Costa JM, Giovangrandi Y, Ernault P, Lohmann L, Nataf V, El Halali N, et al. Fetal RHD genotyping in maternal serum during the first trimester of pregnancy. Br J Haematol. 2002;119(1):255-60.

97. Turner MJ, Martin CM, O'Leary JJ. Detection of fetal Rhesus D gene in whole blood of women booking for routine antenatal care. Eur J Obstet Gynecol Reprod Biol. 2003;108(1):29-32.

98. Randen I, Hauge R, Kjeldsen-Kragh J, Fagerhol MK. Prenatal genotyping of RHD and SRY using maternal blood. Vox Sang. 2003; 85(4):300-6.

99. Rijnders RJ, Christiaens GC, de Haas M, van der Schoot CE. [Fetal DNA in maternal blood]. Ned Tijdschr Geneeskd. 2004;148(4):170-4.

100. Hromadnikova I, Vechetova L, Vesela K, Benesova B, Doucha J, Kulovany E, et al. Non-invasive fetal RHD exon 7 and exon 10 genotyping using real-time PCR testing of fetal DNA in maternal plasma. Fetal Diagn Ther. 2005;20(4):275-80.

101. Van der Schoot CE, Soussan AA, Koelewijn J, Bonsel G, PagetChristiaens LG, de Haas M. Non-invasive antenatal RHD typing. Transfus Clin Biol 2006;13:53-7.

102. Rouillac-Le Sciellour C, Puillandre P, Gillot R, Baulard C, Métral S, Le Van Kim C, et al. Large-scale pre-diagnosis study of fetal RHD genotyping by PCR on plasma DNA from RhD-negative pregnant women. Mol Diagn. 2004;8(1):23-31.

103. Minon JM, Gerard C, Senterre JM, Schaaps JP, Foidart JM. Routine fetal RHD genotyping with maternal plasma: a four-year experience in Belgium. Transfusion. 2008;48(2):373-81. 
104. Chinen PA, Nardozza LM, Martinhago CD, Camano L, Daher S, Pares $\mathrm{DB}$, et al. Noninvasive determination of fetal rh blood group, $\mathrm{D}$ antigen status by cell-free DNA analysis in maternal plasma: experience in a Brazilian population. Am J Perinatol. 2010;27(10):759-62.

105. Amaral DR, Credidio DC, Pellegrino J, Castilho L. Fetal RHD genotyping by analysis of maternal plasma in a mixed population. J Clin Lab Anal. 2011;25(2):100-4.

106. De Hass $M$, Van der Ploeg CPB, Scheffer PG, Verlinden DA, Hirschberg $H$, Abbink $F$, et al. A nation-wide fetal RHD screening programme for targeted antenatal and posnatal anti-D. ISBT Sci Ser. 2012;7:164-7

107. Daniels G, Finning K, Wade A, Massey E, Soothill P, Martin WL et al. Implementation of routine of fetal RHD typing in all RHD-negative pregnant women: timing, costs, and efficiency. Vox Sang. 2012:103 (suppl 1):34.

108. Dovč-Drnovšek T, Klemenc P, Toplak N, Blejec T, Bricl I, Rožman P. Reliable determination of fetal RhD status by RHD genotyping from maternal Plasma. Transfus Med Hemother. 2013;40(1):37-43.

109. Grande M, Ordoñez E, Cirigliano V, Cid J, Grau E, Pericot A, et al. Clinical application of midtrimester non-invasive fetal RHD genotyping and identification of RHD variants in a mixed-ethnic population. Prenat Diagn. 2013;33(2):173-8.

110. Schmidt LC, Cabral AC, Faria MA, Monken F, Tarazona-Santos E, Martins ML. Noninvasive fetal RHD genotyping from maternal plasma in an admixed Brazilian population. Genet Mol Res. 2014;13(1):799-805. 
111. Chiu RW, Poon LL, Lau TK, Leung TN, Wong EM, Lo YM. Effects of blood-processing protocols on fetal and total DNA quantification in maternal plasma. Clin Chem. 2001;47(9):1607-13.

112. MagNA Pure Compact Nucleic Acid Isolation Kit I - Large Volume [catálogo]. Cat. No. 03730972001. Roche; 2010. p. 1-24.

113. Maaskant-van Wijk PA, Faas $B H$, de Ruijter JA, Overbeeke MA, von dem Borne AE, van Rhenen DJ, et al. Genotyping of RHD by multiplex polymerase chain reaction analysis of six RHD-specific ÉXONs. Transfusion. 1998;38(11-12):1015-21.

114. SIGTAP, Sistema de Gerenciamento da Tabela de Procedimentos, Medicamentos e OPM do SUS [29 jun 2015]. Disponível em: http://sigtap.datasus.gov.br/tabela-unificada/app/sec/inicio.jsp.

115. Prudhomme C, D'Vernois JF. Guia Farmacêutico - BRASINDICE. 828, Ano 51. São Paulo: Andrei; 2015.

116. Huang DJ, Zimmermann BG, Holzgreve W, Hahn S. Use of an automated method improves the yield and quality of cell free fetal DNA extracted from maternal plasma. Clin Chem. 2005 Dec;51(12):2419-20.

117. Illanes S, Denbow M, Kailasam C, Finning K, Soothill PW. Early detection of cell-free fetal DNA in maternal plasma. Early Hum Dev. 2007 Sep;83(9):563-6.

118. Devaney SA, Palomaki GE, Scott JA, Bianchi DW. Noninvasive fetal sex determination using cell-free fetal DNA: a systematic review and meta-analysis. JAMA. 2011 Aug 10;306(6):627-36.

119. Meisel H, Reip A, Faltus B, Lu M, Porst H, Wiese M, et al. Transmission of hepatitis $\mathrm{C}$ virus to children and husbands by women infected with 
contaminated anti-D immunoglobulin. Lancet 1995 May 13;345(8959): 1209-11.

120. Kenny-Walsh E. Clinical outcomes after hepatitis $C$ infection from contaminated anti-D immune globulin. Irish Hepatology Research Group. N Engl J Med. 1999 Apr 22;340(16):1228-33.

121. De Haas M. van der Schoot E. Prenatal screnning. ISBT Sci Ser. 2013:8:6-10. 
Dados clínicos e resultados laboratoriais da casuística

\section{Legenda}

IG: Idade gestacional

TS: Tipagem sanguínea

RN: Recém-nascido

Éxon 5 : gene $R H D$

Éxon 7 : gene $R H D$

CCR5: gene CCR5

$R H D \Psi:$ Pseudogene RHD $\Psi$

ND: Não determinado

$F$ : Feminino

M: Masculino 


\begin{tabular}{|c|c|c|c|c|c|c|c|c|c|c|c|c|c|c|}
\hline AMOSTRA & IG & $\begin{array}{c}\text { TS } \\
\text { MATERNA }\end{array}$ & TS RN1 & $\begin{array}{c}\text { SEXO } \\
\text { RN1 }\end{array}$ & TS RN2 & $\begin{array}{c}\text { SEXO } \\
\text { RN2 }\end{array}$ & $\begin{array}{l}\text { ÉXON } 5 \\
\text { EX5T_1 }\end{array}$ & $\begin{array}{l}\text { ÉXON } 5 \\
\text { EX5T_2 }\end{array}$ & $\begin{array}{l}\text { ÉXON } 5 \\
\text { EX5T_3 }\end{array}$ & $\begin{array}{l}\text { ÉXON } 5 \\
\text { Média }\end{array}$ & $\begin{array}{l}\text { ÉXON } 7 \\
968 T \_1\end{array}$ & $\begin{array}{l}\text { ÉXON } 7 \\
968 T \_2\end{array}$ & $\begin{array}{l}\text { ÉXON } \\
968 T \_3\end{array}$ & $\begin{array}{c}\text { ÉXON } 7 \\
\text { Média }\end{array}$ \\
\hline 2 & 23 & O RhD- & O RhD- & $\mathrm{M}$ & & & ND & ND & ND & ND & 35,61 & 36,88 & 36,03 & 36,18 \\
\hline 7 & 28 & O RhD- & O RhD- & $M$ & O RhD- & $\mathrm{F}$ & ND & ND & ND & ND & ND & ND & ND & ND \\
\hline 11 & 25 & A RhD- & $\mathrm{ORhD+}$ & $M$ & & & 38,77 & 46,97 & 41,56 & 42,43 & 38,23 & 43,85 & 40,35 & 40,81 \\
\hline 13 & 22 & O RhD- & O RhD- & $\mathrm{F}$ & & & ND & ND & ND & ND & ND & ND & ND & ND \\
\hline 14 & 20 & O RhD- & $\mathrm{O} \mathrm{RhD}+$ & $\mathrm{F}$ & & & 37,42 & 38,49 & 40,66 & 38,86 & 39,96 & 39,35 & 41,42 & 40,24 \\
\hline 15 & 13 & O RhD- & B RhD- & $\mathrm{F}$ & & & ND & ND & ND & ND & ND & ND & ND & ND \\
\hline 16 & 27 & O RhD- & O RhD+ & $\mathrm{F}$ & & & 35,93 & 36,96 & 36,33 & 36,41 & 39,35 & 39,96 & 37,73 & 39,01 \\
\hline 18 & 27 & B RhD- & A RhD+ & M & & & 37,06 & 36,91 & 39,91 & 37,96 & 40,56 & 40,45 & 38,86 & 39,96 \\
\hline 24 & 15 & O RhD- & O RhD- & $\mathrm{F}$ & O RhD- & $\mathrm{F}$ & ND & ND & ND & ND & ND & ND & ND & ND \\
\hline 25 & 23 & O RhD- & $\mathrm{O}$ RhD+ & $\mathrm{F}$ & & & 33,56 & 33,05 & 32,69 & 33,10 & 36,15 & 36,12 & 35,56 & 35,94 \\
\hline 26 & 16 & O RhD- & $\mathrm{O} \mathrm{RhD}+$ & M & & & 36,33 & 37,15 & 36,38 & 36,62 & ND & 40,69 & 40,22 & 40,46 \\
\hline 28 & 12 & O RhD- & O RhD- & M & & & ND & ND & & ND & ND & ND & & ND \\
\hline 31 & 24 & B RhD- & B RhD- & $\mathrm{F}$ & & & ND & ND & ND & ND & 36,84 & 37,92 & 37,00 & 37,25 \\
\hline 32 & 19 & A RhD- & A RhD+ & $\mathrm{F}$ & & & 37,44 & 36,01 & 38,31 & 37,25 & 42,40 & 39,43 & 40,72 & 40,85 \\
\hline 34 & 27 & O RhD- & $\mathrm{O}$ RhD+ & $\mathrm{F}$ & & & 37,85 & 36,36 & 36,85 & 37,02 & 39,40 & 36,99 & 37,45 & 37,95 \\
\hline 36 & 16 & B RhD- & $\mathrm{B} \mathrm{RhD+}$ & $\mathrm{F}$ & & & 40,04 & 42,38 & 43,28 & 41,90 & 38,90 & 39,35 & 40,78 & 39,68 \\
\hline 39 & 21 & A RhD- & A RhD+ & M & & & 36,17 & 39,67 & 36,00 & 37,28 & 39,61 & 42,18 & 39,37 & 40,39 \\
\hline 41 & 25 & B RhD- & B RhD+ & $\mathrm{F}$ & & & 35,45 & 34,94 & 36,27 & 35,56 & 37,40 & 37,56 & 37,89 & 37,62 \\
\hline 42 & 28 & B RhD- & O RhD- & $\mathrm{F}$ & & & ND & ND & ND & ND & ND & ND & ND & ND \\
\hline 43 & 13 & A RhD- & A RhD+ & $\mathrm{F}$ & & & 36,08 & 36,29 & 36,01 & 36,13 & 35,78 & 35,53 & 35,32 & 35,54 \\
\hline 44 & 28 & O RhD- & A RhD+ & $\mathrm{F}$ & & & 33,95 & 35,63 & 35,10 & 34,89 & ND & 35,40 & 35,22 & 35,31 \\
\hline 45 & 21 & A RhD- & $\mathrm{O} \mathrm{RhD}^{+}$ & M & & & & 34,85 & 35,67 & 35,26 & & 36,99 & 36,31 & 36,65 \\
\hline 46 & 17 & B RhD- & $\mathrm{O} \mathrm{RhD}+$ & M & & & 39,95 & 38,92 & ND & 39,43 & 39,53 & 39,99 & 41,38 & 40,30 \\
\hline 47 & 23 & A RhD- & A RhD- & M & & & ND & ND & ND & ND & ND & ND & ND & ND \\
\hline 48 & 28 & AB RhD- & $\mathrm{B} \mathrm{RhD+}$ & M & & & 35,28 & 35,07 & 35,16 & 35,17 & 39,92 & 37,85 & 37,09 & 38,29 \\
\hline
\end{tabular}




\begin{tabular}{|c|c|c|c|c|c|c|c|c|c|c|c|c|c|c|}
\hline AMOSTRA & IG & $\begin{array}{c}\text { TS } \\
\text { MATERNA }\end{array}$ & TS RN1 & $\begin{array}{c}\text { SEXO } \\
\text { RN1 }\end{array}$ & TS RN2 & $\begin{array}{l}\text { SEXO } \\
\text { RN2 }\end{array}$ & $\begin{array}{l}\text { ÉXON } 5 \\
\text { EX5T_1 }\end{array}$ & $\begin{array}{l}\text { ÉXON } 5 \\
\text { EX5T_2 }\end{array}$ & $\begin{array}{l}\text { ÉXON } 5 \\
\text { EX5T_3 }\end{array}$ & $\begin{array}{l}\text { ÉXON } 5 \\
\text { Média }\end{array}$ & $\begin{array}{l}\text { ÉXON } 7 \\
968 T \_1\end{array}$ & $\begin{array}{l}\text { ÉXON } 7 \\
968 T \_2\end{array}$ & $\begin{array}{l}\text { ÉXON } \\
\text { 968T_3 }\end{array}$ & $\begin{array}{c}\text { ÉXON } 7 \\
\text { Média }\end{array}$ \\
\hline 50 & 12 & A RhD- & AB RhD+ & $\mathrm{F}$ & & & 37,18 & 37,85 & 37,48 & 37,51 & 38,81 & 39,64 & 39,15 & 39,20 \\
\hline 51 & 27 & O RhD- & O RhD+ & $M$ & & & 34,84 & 34,59 & 35,68 & 35,04 & 37,27 & 37,66 & 37,29 & 37,41 \\
\hline 52 & 27 & O RhD- & O RhD+ & $M$ & & & 36,57 & 34,62 & 35,00 & 35,40 & 36,85 & 36,83 & 36,80 & 36,82 \\
\hline 53 & 25 & O RhD- & O RhD+ & M & & & 37,61 & 40,62 & 36,77 & 38,33 & 39,02 & 41,23 & 38,99 & 39,75 \\
\hline 54 & 12 & A RhD- & A RhD+ & M & & & 30,71 & 30,86 & 31,58 & 31,05 & 32,97 & 32,82 & 33,24 & 33,01 \\
\hline 55 & 13 & O RhD- & O RhD+ & $\mathrm{F}$ & & & 34,88 & 36,55 & 35,94 & 35,79 & 40,03 & 36,77 & 40,44 & 39,08 \\
\hline 56 & 19 & B RhD- & O RhD+ & $\mathrm{F}$ & & & & 39,48 & 39,00 & 39,24 & & 38,19 & 39,76 & 38,98 \\
\hline 57 & 10 & A RhD- & O RhD+ & M & & & 36,02 & 37,08 & 37,31 & 36,80 & 38,09 & 37,19 & 37,47 & 37,58 \\
\hline 58 & 21 & AB RhD- & B RhD- & $\mathrm{F}$ & & & ND & ND & ND & ND & ND & ND & ND & ND \\
\hline 59 & 10 & AB RhD- & A RhD+ & $\mathrm{F}$ & & & 37,21 & 37,99 & 36,48 & 37,23 & 37,88 & 37,27 & 37,35 & 37,50 \\
\hline 60 & 23 & A RhD- & O RhD+ & M & & & 35,22 & 34,81 & 35,44 & 35,15 & 36,88 & 36,13 & 37,97 & 36,99 \\
\hline 61 & 23 & A RhD- & A RhD+ & M & & & 38,89 & 37,13 & 37,75 & 37,92 & 38,11 & 40,94 & 38,44 & 39,16 \\
\hline 62 & 22 & O RhD- & A RhD+ & $\mathrm{M}$ & & & 37,85 & 35,96 & 38,65 & 37,49 & 40,29 & 39,19 & 38,95 & 39,48 \\
\hline 63 & 18 & O RhD- & B RhD+ & $\mathrm{F}$ & & & 37,08 & 36,14 & 37,02 & 36,75 & 40,52 & 37,31 & 39,06 & 38,96 \\
\hline 64 & 15 & A RhD- & A RhD+ & $M$ & & & 38,22 & 35,33 & 37,51 & 37,02 & 37,98 & 37,91 & 43,33 & 39,74 \\
\hline 65 & 27 & O RhD- & O RhD+ & $M$ & & & 41,56 & 41,73 & 42,15 & 41,81 & 41,09 & 41,07 & 43,18 & 41,78 \\
\hline 66 & 25 & O RhD- & A RhD+ & $M$ & & & 40,96 & 45,39 & 41,82 & 42,72 & 38,97 & 44,65 & 41,11 & 41,57 \\
\hline 67 & 16 & O RhD- & O RhD+ & $M$ & & & 44,55 & 38,75 & 41,66 & 41,65 & 41,27 & 38,44 & 42,00 & 40,57 \\
\hline 68 & 23 & O RhD- & O RhD+ & $\mathrm{F}$ & & & 42,12 & 40,10 & 41,75 & 41,33 & 35,94 & 34,80 & 36,53 & 35,76 \\
\hline 70 & 19 & O RhD- & O RhD- & $\mathrm{F}$ & & & ND & ND & ND & ND & ND & ND & ND & ND \\
\hline 72 & 24 & O RhD- & O RhD+ & $M$ & & & 40,36 & 42,10 & 42,69 & 41,72 & 37,91 & 38,42 & 41,61 & 39,31 \\
\hline 73 & 22 & A RhD- & A RhD- & $M$ & & & ND & ND & ND & ND & ND & ND & ND & ND \\
\hline 74 & 20 & O RhD- & B RhD- & $M$ & & & ND & ND & ND & ND & ND & ND & ND & ND \\
\hline 75 & 28 & O RhD- & O RhD+ & $\mathrm{F}$ & & & 33,88 & 34,50 & 34,30 & 34,23 & 34,96 & 34,51 & 35,16 & 34,88 \\
\hline 76 & 12 & O RhD- & O RhD+ & $M$ & & & 36,46 & 35,05 & 36,67 & 36,06 & 39,12 & 37,47 & 35,98 & 37,52 \\
\hline 77 & 19 & B RhD- & O RhD- & $\mathrm{F}$ & & & ND & ND & ND & ND & ND & ND & ND & ND \\
\hline 78 & 27 & O RhD- & O RhD- & $M$ & & & ND & ND & ND & ND & ND & ND & ND & ND \\
\hline
\end{tabular}




\begin{tabular}{|c|c|c|c|c|c|c|c|c|c|c|c|c|c|c|}
\hline AMOSTRA & IG & $\begin{array}{c}\text { TS } \\
\text { MATERNA }\end{array}$ & TS RN1 & $\begin{array}{c}\text { SEXO } \\
\text { RN1 }\end{array}$ & TS RN2 & $\begin{array}{c}\text { SEXO } \\
\text { RN2 }\end{array}$ & $\begin{array}{l}\text { ÉXON } 5 \\
\text { EX5T_1 }\end{array}$ & $\begin{array}{l}\text { ÉXON } 5 \\
\text { EX5T_2 }\end{array}$ & $\begin{array}{l}\text { ÉXON } 5 \\
\text { EX5T_3 }\end{array}$ & $\begin{array}{l}\text { ÉXON } 5 \\
\text { Média }\end{array}$ & $\begin{array}{l}\text { ÉXON } 7 \\
968 T \_1\end{array}$ & $\begin{array}{l}\text { ÉXON } 7 \\
968 T \_2\end{array}$ & $\begin{array}{l}\text { ÉXON } \\
968 T \_3\end{array}$ & $\begin{array}{l}\text { ÉXON } 7 \\
\text { Média }\end{array}$ \\
\hline 79 & 16 & O RhD- & O RhD+ & $\mathrm{F}$ & & & 40,64 & & 40,77 & 40,71 & 39,97 & & 39,42 & 39,70 \\
\hline 80 & 13 & O RhD- & A RhD+ & M & & & 36,84 & ND & 36,36 & 36,60 & 39,47 & 39,29 & 37,99 & 38,92 \\
\hline 81 & 13 & A RhD- & A RhD+ & M & & & 38,04 & 37,73 & 37,70 & 37,82 & 37,65 & 36,02 & 36,70 & 36,79 \\
\hline 82 & 11 & O RhD- & O RhD+ & $\mathrm{F}$ & & & 37,01 & 36,87 & 36,94 & 36,94 & 37,63 & 38,01 & 36,68 & 37,44 \\
\hline 83 & 17 & A RhD- & $\mathrm{O} \mathrm{RhD}+$ & $\mathrm{F}$ & & & 34,68 & 35,44 & 35,71 & 35,28 & 36,89 & 37,22 & 36,32 & 36,81 \\
\hline 84 & 23 & B RhD- & O RhD- & M & & & ND & ND & ND & ND & ND & ND & ND & ND \\
\hline 85 & 25 & B RhD- & $\mathrm{O}$ RhD+ & M & & & 35,57 & 37,09 & 35,80 & 36,15 & 36,84 & 36,88 & 36,76 & 36,83 \\
\hline 86 & 28 & B RhD- & B RhD- & $\mathrm{F}$ & & & ND & ND & ND & ND & ND & ND & ND & ND \\
\hline 87 & 26 & O RhD- & O RhD+ & $M$ & O RhD+ & M & 38,48 & 38,16 & 38,95 & 38,53 & 36,73 & 38,40 & 36,73 & 37,29 \\
\hline 88 & 24 & A RhD- & A RhD+ & $\mathrm{F}$ & & & 39,96 & 40,68 & 40,98 & 40,54 & 38,72 & 38,81 & 46,91 & 41,48 \\
\hline 89 & 27 & O RhD- & O RhD+ & M & & & 34,66 & 34,74 & 34,60 & 34,67 & 36,14 & 36,62 & 35,66 & 36,14 \\
\hline 90 & 9 & O RhD- & B RhD- & M & & & ND & ND & ND & ND & ND & ND & ND & ND \\
\hline 91 & 25 & A RhD- & A RhD+ & M & & & 39,92 & 39,43 & & 39,67 & 39,76 & 38,27 & & 39,02 \\
\hline 92 & 22 & O RhD- & O RhD- & M & & & ND & ND & ND & ND & ND & ND & ND & ND \\
\hline 93 & 27 & O RhD- & O RhD+ & $\mathrm{F}$ & & & 35,53 & 37,52 & 45,71 & 39,59 & 36,96 & 36,71 & 46,91 & 40,19 \\
\hline 94 & 24 & AB RhD- & B RhD+ & M & & & 40,19 & 38,06 & 39,53 & 39,26 & 43,98 & 37,93 & 38,40 & 40,11 \\
\hline 95 & 7 & B RhD- & B RhD- & $\mathrm{F}$ & & & ND & ND & ND & ND & ND & ND & ND & ND \\
\hline 96 & 21 & A RhD- & AB RhD- & $M$ & & & ND & ND & ND & ND & 36,53 & 36,01 & 35,29 & 35,94 \\
\hline 97 & 22 & A RhD- & A RhD+ & $M$ & & & 38,98 & 39,59 & & 39,28 & 37,96 & 40,09 & & 39,03 \\
\hline 98 & 20 & O RhD- & O RhD- & $\mathrm{F}$ & & & ND & ND & & ND & ND & ND & & ND \\
\hline 99 & 21 & B RhD- & B RhD+ & $\mathrm{F}$ & & & 39,26 & 38,56 & 38,57 & 38,80 & 38,23 & 38,45 & 39,78 & 38,82 \\
\hline 100 & 9 & O RhD- & O RhD+ & $M$ & & & 36,47 & 33,38 & 34,05 & 34,63 & 37,30 & 33,64 & 33,76 & 34,90 \\
\hline 101 & 17 & O RhD- & A RhD- & $M$ & & & ND & ND & ND & ND & ND & ND & ND & ND \\
\hline 102 & 20 & A RhD- & A RhD- & $\mathrm{F}$ & A RhD- & $M$ & ND & ND & ND & ND & ND & ND & ND & ND \\
\hline 103 & 25 & O RhD- & A RhD- & $M$ & & & ND & ND & ND & ND & ND & ND & ND & ND \\
\hline 104 & 27 & A RhD- & A RhD+ & M & & & 34,58 & 34,37 & 34,23 & 34,39 & 35,22 & 34,21 & 34,11 & 34,51 \\
\hline 105 & 15 & O RhD- & O RhD- & M & & & ND & ND & ND & ND & ND & ND & ND & ND \\
\hline
\end{tabular}




\begin{tabular}{|c|c|c|c|c|c|c|c|c|c|c|c|c|c|c|}
\hline AMOSTRA & IG & \begin{tabular}{c|} 
TS \\
MATERNA
\end{tabular} & TS RN1 & $\begin{array}{c}\text { SEXO } \\
\text { RN1 }\end{array}$ & TS RN2 & $\begin{array}{c}\text { SEXO } \\
\text { RN2 }\end{array}$ & $\begin{array}{l}\text { ÉXON } 5 \\
\text { EX5T_1 }\end{array}$ & $\begin{array}{l}\text { ÉXON } 5 \\
\text { EX5T_2 }\end{array}$ & $\begin{array}{l}\text { ÉXON } 5 \\
\text { EX5T_3 }\end{array}$ & $\begin{array}{l}\text { ÉXON } 5 \\
\text { Média }\end{array}$ & $\begin{array}{l}\text { ÉXON } 7 \\
968 T \text { 1 }\end{array}$ & $\begin{array}{l}\text { ÉXON } 7 \\
968 T \_2\end{array}$ & $\begin{array}{l}\text { ÉXON } \\
968 T \_3\end{array}$ & $\begin{array}{c}\text { ÉXON } 7 \\
\text { Média }\end{array}$ \\
\hline 106 & 27 & O RhD- & O RhD+ & $\mathrm{F}$ & & & 36,18 & 35,37 & 35,15 & 35,57 & 35,77 & 35,39 & 35,78 & 35,65 \\
\hline 107 & 27 & A RhD- & A RhD+ & $\mathrm{F}$ & & & 35,58 & 36,97 & 37,39 & 36,65 & 37,35 & 37,53 & 37,95 & 37,61 \\
\hline 108 & 26 & B RhD- & B RhD+ & $M$ & & & 38,65 & 37,90 & 38,70 & 38,42 & 38,93 & 38,86 & 37,58 & 38,46 \\
\hline 110 & 27 & B RhD- & B RhD+ & $M$ & & & 35,77 & 34,32 & 34,42 & 34,84 & 37,98 & 36,44 & 35,89 & 36,77 \\
\hline 111 & 17 & A RhD- & O RhD+ & $M$ & & & 39,35 & 38,57 & 39,42 & 39,12 & 40,70 & 39,25 & 40,88 & 40,28 \\
\hline 112 & 9 & O RhD- & O RhD+ & $\mathrm{F}$ & & & 37,32 & 37,56 & 37,04 & 37,31 & 38,63 & 39,20 & 39,05 & 38,96 \\
\hline 113 & 19 & B RhD- & O RhD+ & $M$ & & & 37,59 & 38,23 & 37,46 & 37,76 & 39,85 & 39,03 & ND & 39,44 \\
\hline 114 & 13 & O RhD- & O RhD- & $M$ & & & ND & ND & ND & ND & ND & ND & ND & ND \\
\hline 115 & 21 & O RhD- & B RhD+ & $\mathrm{F}$ & & & 38,36 & 38,17 & 36,31 & 37,61 & 39,12 & 38,21 & 38,56 & 38,63 \\
\hline 116 & 23 & B RhD- & A RhD+ & $\mathrm{F}$ & & & 39,53 & 39,23 & 42,87 & 40,54 & 38,21 & 38,76 & 46,40 & 41,12 \\
\hline 117 & 18 & O RhD- & O RhD+ & $\mathrm{F}$ & & & 36,33 & 37,34 & 38,96 & 37,54 & 38,74 & 43,03 & 38,96 & 40,25 \\
\hline 118 & 28 & A RhD- & A RhD+ & $\mathrm{F}$ & & & 37,56 & 36,65 & 37,64 & 37,28 & 38,40 & 37,47 & 38,35 & 38,07 \\
\hline 119 & 11 & O RhD- & O RhD+ & $\mathrm{F}$ & & & 37,39 & 36,47 & ND & 36,93 & ND & 36,80 & 37,41 & 37,10 \\
\hline 120 & 15 & B RhD- & B RhD- & M & & & ND & ND & ND & ND & ND & ND & ND & ND \\
\hline 121 & 12 & O RhD- & O RhD+ & $\mathrm{F}$ & & & 36,17 & 37,74 & 36,70 & 36,87 & 37,29 & 39,16 & 38,43 & 38,30 \\
\hline 122 & 24 & O RhD- & O RhD+ & $\mathrm{F}$ & & & 35,54 & 35,22 & 33,50 & 34,75 & 36,49 & 35,58 & 35,47 & 35,85 \\
\hline 124 & 27 & O RhD- & O RhD+ & $\mathrm{F}$ & & & 31,14 & 31,22 & 31,03 & 31,13 & 32,48 & 32,76 & 31,80 & 32,35 \\
\hline 125 & 27 & O RhD- & O RhD+ & $\mathrm{F}$ & & & 35,74 & 35,30 & 36,64 & 35,89 & 35,70 & 35,81 & 36,59 & 36,03 \\
\hline 126 & 20 & A RhD- & A RhD+ & $M$ & & & 43,12 & 38,43 & 39,72 & 40,42 & 41,94 & 37,83 & 40,20 & 39,99 \\
\hline 127 & 28 & O RhD- & O RhD+ & $M$ & & & 36,63 & 34,64 & 34,75 & 35,34 & 36,39 & 36,44 & 37,31 & 36,71 \\
\hline 128 & 24 & A RhD- & A RhD+ & $\mathrm{F}$ & & & 38,47 & 37,32 & 38,03 & 37,94 & 39,88 & 38,86 & 39,46 & 39,40 \\
\hline 130 & 13 & AB RhD- & A RhD- & $M$ & & & ND & ND & ND & ND & ND & ND & ND & ND \\
\hline 131 & 23 & O RhD- & A RhD- & $M$ & & & ND & ND & ND & ND & ND & ND & ND & ND \\
\hline 132 & 28 & A RhD- & A RhD+ & $M$ & & & 38,57 & 40,29 & 38,78 & 39,22 & 40,18 & 41,08 & 39,79 & 40,35 \\
\hline 133 & 12 & A RhD- & O RhD+ & $\mathrm{F}$ & & & 38,08 & 38,75 & 39,21 & 38,68 & 39,84 & 41,43 & 41,37 & 40,88 \\
\hline 134 & 12 & O RhD- & O RhD- & $\mathrm{F}$ & & & ND & ND & ND & ND & ND & ND & ND & ND \\
\hline 135 & 23 & O RhD- & A RhD- & $M$ & & & ND & ND & ND & ND & ND & ND & ND & ND \\
\hline
\end{tabular}




\begin{tabular}{|c|c|c|c|c|c|c|c|c|c|c|c|c|c|c|}
\hline AMOSTRA & IG & $\begin{array}{c}\text { TS } \\
\text { MATERNA }\end{array}$ & TS RN1 & $\begin{array}{c}\text { SEXO } \\
\text { RN1 }\end{array}$ & TS RN2 & $\begin{array}{l}\text { SEXO } \\
\text { RN2 }\end{array}$ & $\begin{array}{l}\text { ÉXON } 5 \\
\text { EX5T_1 }\end{array}$ & $\begin{array}{l}\text { ÉXON } 5 \\
\text { EX5T_2 }\end{array}$ & $\begin{array}{l}\text { ÉXON } 5 \\
\text { EX5T_3 }\end{array}$ & $\begin{array}{l}\text { ÉXON } 5 \\
\text { Média }\end{array}$ & $\begin{array}{l}\text { ÉXON } 7 \\
968 T \_1\end{array}$ & $\begin{array}{l}\text { ÉXON } 7 \\
968 T \_2\end{array}$ & $\begin{array}{l}\text { ÉXON } \\
968 T \_3\end{array}$ & $\begin{array}{l}\text { ÉXON } 7 \\
\text { Média }\end{array}$ \\
\hline 136 & 28 & O RhD- & A RhD- & M & A RhD- & M & ND & ND & ND & ND & ND & ND & ND & ND \\
\hline 137 & 22 & O RhD- & O RhD- & $\mathrm{F}$ & & & ND & ND & ND & ND & ND & ND & ND & ND \\
\hline 138 & 24 & O RhD- & O RhD+ & $\mathrm{F}$ & O RhD+ & $\mathrm{F}$ & 33,42 & 32,85 & 32,68 & 32,98 & 35,24 & 35,46 & 35,71 & 35,47 \\
\hline 139 & 26 & O RhD- & A RhD+ & M & & & 35,07 & ND & 34,98 & 35,02 & 38,08 & 36,77 & 37,90 & 37,58 \\
\hline 140 & 19 & A RhD- & A RhD- & $\mathrm{F}$ & & & ND & ND & ND & ND & ND & ND & ND & ND \\
\hline 141 & 11 & O RhD- & A RhD- & M & & & ND & ND & ND & ND & ND & ND & ND & ND \\
\hline 142 & 20 & O RhD- & O RhD+ & M & & & 37,81 & 37,00 & 38,79 & 37,87 & 37,34 & 38,22 & 37,45 & 37,67 \\
\hline 143 & 28 & O RhD- & O RhD+ & $M$ & & & 35,53 & 36,17 & 36,09 & 35,93 & 35,16 & 36,67 & 36,77 & 36,20 \\
\hline 144 & 22 & A RhD- & A RhD+ & $\mathrm{F}$ & & & 33,21 & 32,94 & 33,88 & 33,34 & 33,96 & 33,66 & 34,33 & 33,98 \\
\hline 146 & 12 & O RhD- & A RhD+ & $\mathrm{F}$ & & & 36,19 & 35,85 & 36,08 & 36,04 & 36,31 & 36,38 & 37,14 & 36,61 \\
\hline 147 & 10 & O RhD- & O RhD- & $\mathrm{F}$ & & & ND & ND & ND & ND & ND & ND & ND & ND \\
\hline 148 & 25 & A RhD- & A RhD- & $\mathrm{F}$ & & & ND & ND & ND & ND & ND & ND & ND & ND \\
\hline 149 & 11 & O RhD- & A RhD+ & $\mathrm{F}$ & & & 38,98 & 38,88 & 40,46 & 39,44 & 37,58 & 37,42 & 39,51 & 38,17 \\
\hline 150 & 22 & A RhD- & A RhD+ & $\mathrm{F}$ & & & 36,40 & 37,76 & 34,95 & 36,37 & 38,16 & 36,51 & 36,73 & 37,13 \\
\hline 151 & 12 & O RhD- & A RhD- & $\mathrm{F}$ & & & ND & ND & ND & ND & ND & ND & ND & ND \\
\hline 152 & 13 & A RhD- & A RhD- & $\mathrm{F}$ & & & ND & ND & ND & ND & 32,71 & 33,50 & 33,66 & 33,29 \\
\hline 153 & 19 & A RhD- & A RhD+ & M & & & 37,17 & 35,93 & 37,11 & 36,74 & 38,75 & 36,32 & 38,52 & 37,86 \\
\hline 154 & 26 & O RhD- & O RhD+ & M & & & 34,01 & 33,55 & 34,34 & 33,97 & 33,99 & 33,88 & 34,13 & 34,00 \\
\hline 155 & 19 & B RhD- & AB RhD- & $M$ & & & ND & ND & ND & ND & ND & ND & ND & ND \\
\hline 157 & 14 & O RhD- & A RhD+ & $M$ & & & 37,03 & 36,92 & 35,96 & 36,64 & 39,16 & 37,88 & 38,67 & 38,57 \\
\hline 158 & 19 & B RhD- & A RhD- & $M$ & & & ND & ND & ND & ND & ND & ND & ND & ND \\
\hline 159 & 18 & AB RhD- & B RhD+ & $\mathrm{F}$ & & & 37,71 & 37,95 & ND & 37,83 & 42,21 & 40,25 & 41,66 & 41,37 \\
\hline 160 & 16 & A RhD- & AB RhD- & $M$ & & & ND & ND & ND & ND & 32,68 & 33,35 & 33,69 & 33,24 \\
\hline 161 & 14 & O RhD- & O RhD+ & $\mathrm{F}$ & O RhD- & $\mathrm{F}$ & 35,83 & 37,88 & 35,25 & 36,32 & 37,55 & 39,12 & 41,65 & 39,44 \\
\hline 162 & 28 & A RhD- & AB RhD+ & M & & & 34,80 & 36,10 & 34,51 & 35,14 & 37,53 & 37,13 & 35,20 & 36,62 \\
\hline 163 & 17 & O RhD- & O RhD+ & $\mathrm{F}$ & & & 38,05 & 35,05 & 36,66 & 36,59 & 37,20 & 37,08 & 38,45 & 37,58 \\
\hline 164 & 26 & AB RhD- & A RhD+ & M & & & ND & 35,43 & 37,46 & 36,45 & 36,04 & 36,88 & 37,19 & 36,70 \\
\hline
\end{tabular}




\begin{tabular}{|c|c|c|c|c|c|c|c|c|c|c|c|c|c|c|}
\hline AMOSTRA & IG & \begin{tabular}{c|} 
TS \\
MATERNA
\end{tabular} & TS RN1 & $\begin{array}{c}\text { SEXO } \\
\text { RN1 }\end{array}$ & TS RN2 & $\begin{array}{c}\text { SEXO } \\
\text { RN2 }\end{array}$ & $\begin{array}{l}\text { ÉXON } 5 \\
\text { EX5T_1 }\end{array}$ & $\begin{array}{l}\text { ÉXON } 5 \\
\text { EX5T_2 }\end{array}$ & $\begin{array}{l}\text { ÉXON } 5 \\
\text { EX5T_3 }\end{array}$ & $\begin{array}{l}\text { ÉXON } 5 \\
\text { Média }\end{array}$ & $\begin{array}{l}\text { ÉXON } 7 \\
968 T \text { 1 }\end{array}$ & $\begin{array}{l}\text { ÉXON } 7 \\
968 T \_2\end{array}$ & $\begin{array}{l}\text { ÉXON } \\
968 T \_3\end{array}$ & $\begin{array}{c}\text { ÉXON } 7 \\
\text { Média }\end{array}$ \\
\hline 165 & 16 & O RhD- & O RhD+ & $\mathrm{F}$ & & & 35,99 & 35,96 & 35,07 & 35,67 & 37,55 & 37,72 & 36,54 & 37,27 \\
\hline 166 & 19 & O RhD- & O RhD+ & $\mathrm{F}$ & & & 35,55 & ND & ND & 35,55 & 38,67 & 37,39 & 38,00 & 38,02 \\
\hline 168 & 12 & A RhD- & A RhD+ & $M$ & & & 37,77 & ND & & 37,77 & 42,92 & 39,38 & & 41,15 \\
\hline 169 & 8 & B RhD- & O RhD+ & $M$ & & & 40,61 & 43,12 & & 41,87 & 41,42 & ND & & 41,42 \\
\hline 170 & 8 & O RhD- & O RhD+ & $M$ & & & 40,35 & 39,40 & 41,36 & 40,37 & 43,53 & 40,73 & 40,97 & 41,74 \\
\hline 171 & 16 & O RhD- & O RhD+ & $\mathrm{F}$ & & & 35,49 & 36,12 & & 35,80 & 39,02 & 40,11 & & 39,56 \\
\hline 172 & 16 & A RhD- & A RhD- & $M$ & & & ND & ND & ND & ND & ND & ND & ND & ND \\
\hline 173 & 18 & A RhD- & A RhD+ & $M$ & & & 39,41 & 42,04 & 40,46 & 40,64 & 38,75 & 40,33 & 39,09 & 39,39 \\
\hline 174 & 24 & O RhD- & O RhD+ & $\mathrm{F}$ & & & 40,02 & 41,82 & 40,23 & 40,69 & 37,59 & 39,25 & 38,22 & 38,35 \\
\hline 175 & 26 & AB RhD- & A RhD+ & $M$ & & & 39,82 & 38,89 & 38,49 & 39,07 & 38,69 & 37,18 & 38,20 & 38,03 \\
\hline 176 & 24 & B RhD- & B RhD+ & $M$ & & & 39,89 & 42,28 & 40,78 & 40,98 & 34,84 & 34,72 & 35,38 & 34,98 \\
\hline 177 & 28 & O RhD- & O RhD+ & $\mathrm{F}$ & & & 38,13 & 37,03 & 35,65 & 36,94 & 35,92 & 34,63 & 33,47 & 34,67 \\
\hline 178 & 20 & O RhD- & O RhD+ & $\mathrm{F}$ & & & 39,99 & 39,11 & 40,59 & 39,90 & 39,20 & 38,17 & 38,92 & 38,76 \\
\hline 179 & 24 & A RhD- & A RhD+ & M & & & 41,71 & 39,49 & 41,50 & 40,90 & 39,99 & 39,58 & 41,43 & 40,34 \\
\hline 180 & 19 & AB RhD- & B RhD+ & $\mathrm{F}$ & & & 39,21 & 38,67 & & 38,94 & 42,51 & 41,81 & & 42,16 \\
\hline 181 & 27 & O RhD- & O RhD+ & $M$ & & & 35,61 & 36,32 & & 35,96 & 39,61 & 40,47 & & 40,04 \\
\hline 182 & 24 & A RhD- & A RhD- & $\mathrm{F}$ & & & ND & ND & & ND & ND & ND & & ND \\
\hline 183 & 22 & O RhD- & O RhD+ & $M$ & & & 38,12 & 37,34 & & 37,73 & 40,40 & 39,97 & & 40,18 \\
\hline 184 & 24 & A RhD- & A RhD+ & $M$ & & & 37,03 & 38,60 & & 37,82 & 41,75 & 41,56 & & 41,65 \\
\hline 185 & 17 & O RhD- & A RhD+ & $\mathrm{F}$ & & & 39,35 & 39,13 & & 39,24 & 43,32 & 40,83 & & 42,08 \\
\hline 186 & 26 & AB RhD- & B RhD+ & $M$ & & & ND & 38,03 & & 38,03 & 40,65 & 39,70 & & 40,17 \\
\hline 187 & 22 & O RhD- & O RhD+ & $M$ & & & 34,32 & 34,72 & & 34,52 & 37,70 & 36,68 & & 37,19 \\
\hline 188 & 24 & O RhD- & O RhD+ & M & & & 34,47 & 33,54 & 34,17 & 34,06 & 36,60 & 36,50 & 37,43 & 36,84 \\
\hline 189 & 21 & A RhD- & B RhD+ & $\mathrm{F}$ & & & ND & ND & ND & ND & 35,85 & 37,97 & 36,75 & 36,86 \\
\hline 190 & 24 & A RhD- & O RhD+ & $\mathrm{F}$ & & & 35,72 & 36,04 & 35,39 & 35,72 & 37,56 & 38,40 & 38,76 & 38,24 \\
\hline 191 & 28 & A RhD- & A RhD- & $\mathrm{F}$ & & & ND & ND & ND & ND & ND & ND & ND & ND \\
\hline 192 & 23 & O RhD- & A RhD+ & $\mathrm{F}$ & A RhD+ & $\mathrm{F}$ & 34,27 & 33,92 & 35,53 & 34,58 & 35,62 & 36,49 & 37,46 & 36,53 \\
\hline
\end{tabular}




\begin{tabular}{|c|c|c|c|c|c|c|c|c|c|c|c|c|c|c|}
\hline AMOSTRA & IG & $\begin{array}{c}\text { TS } \\
\text { MATERNA }\end{array}$ & TS RN1 & \begin{tabular}{|c|} 
SEXO \\
RN1
\end{tabular} & TS RN2 & $\begin{array}{c}\text { SEXO } \\
\text { RN2 }\end{array}$ & $\begin{array}{l}\text { ÉXON } 5 \\
\text { EX5T_1 }\end{array}$ & $\begin{array}{l}\text { ÉXON } 5 \\
\text { EX5T_2 }\end{array}$ & $\begin{array}{l}\text { ÉXON } 5 \\
\text { EX5T_3 }\end{array}$ & $\begin{array}{c}\text { ÉXON } 5 \\
\text { Média }\end{array}$ & $\begin{array}{l}\text { ÉXON } 7 \\
968 T \_1\end{array}$ & $\begin{array}{l}\text { ÉXON } 7 \\
968 T \_2\end{array}$ & $\begin{array}{l}\text { ÉXON } \\
968 T \_3\end{array}$ & $\begin{array}{l}\text { ÉXON } 7 \\
\text { Média }\end{array}$ \\
\hline 194 & 10 & A RhD- & A RhD+ & $M$ & & & 37,04 & 38,40 & 37,95 & 37,80 & 38,43 & 38,43 & 38,65 & 38,50 \\
\hline 195 & 18 & O RhD- & O RhD+ & $\mathrm{F}$ & & & 36,24 & 46,06 & 38,46 & 40,25 & 38,94 & 40,26 & 39,76 & 39,66 \\
\hline 196 & 21 & A RhD- & O RhD+ & $M$ & & & 37,55 & 35,80 & 34,99 & 36,12 & 43,09 & 39,54 & 40,73 & 41,12 \\
\hline 198 & 21 & O RhD- & O RhD+ & $\mathrm{F}$ & & & 34,81 & 39,08 & 46,34 & 40,08 & 39,10 & 43,89 & 45,32 & 42,77 \\
\hline 199 & 16 & B RhD- & B RhD- & $M$ & & & ND & ND & ND & ND & ND & ND & ND & ND \\
\hline 200 & 27 & A RhD- & O RhD+ & $\mathrm{F}$ & & & 33,90 & 33,91 & 34,10 & 33,97 & 43,75 & 39,44 & 37,42 & 40,20 \\
\hline 201 & 21 & A RhD- & A RhD- & $\mathrm{F}$ & & & ND & ND & ND & ND & ND & ND & ND & ND \\
\hline 202 & 22 & A RhD- & O RhD+ & $\mathrm{F}$ & & & 35,28 & 35,45 & 35,17 & 35,30 & 41,83 & 45,91 & 39,74 & 42,49 \\
\hline 203 & 22 & O RhD- & O RhD- & $\mathrm{F}$ & & & ND & ND & ND & ND & ND & ND & ND & ND \\
\hline 204 & 20 & B RhD- & B RhD+ & $M$ & & & 36,90 & 36,88 & 36,84 & 36,87 & 37,87 & 39,54 & 47,40 & 41,60 \\
\hline 205 & 18 & O RhD- & O RhD+ & $\mathrm{F}$ & & & 40,03 & 36,94 & 45,59 & 40,86 & 41,58 & 41,63 & 37,28 & 40,16 \\
\hline 206 & 14 & O RhD- & O RhD+ & $\mathrm{F}$ & & & 37,60 & 35,65 & 36,39 & 36,55 & 40,37 & 36,79 & 36,75 & 37,97 \\
\hline 208 & 28 & O RhD- & O RhD+ & $\mathrm{F}$ & & & 35,68 & 35,29 & 36,87 & 35,95 & 39,18 & 38,67 & 38,12 & 38,65 \\
\hline 209 & 25 & A RhD- & O RhD+ & $M$ & & & ND & ND & ND & ND & 37,47 & 36,88 & 36,09 & 36,81 \\
\hline 210 & 22 & O RhD- & O RhD- & $\mathrm{F}$ & & & ND & ND & ND & ND & ND & ND & ND & ND \\
\hline 211 & 20 & A RhD- & A RhD+ & $M$ & & & 36,36 & 38,84 & 38,39 & 37,86 & 34,76 & 35,92 & 35,36 & 35,34 \\
\hline 212 & 16 & O RhD- & O RhD+ & M & & & 36,20 & 32,97 & 35,25 & 34,81 & 33,53 & 33,31 & 33,71 & 33,52 \\
\hline 213 & 20 & B RhD- & A RhD+ & $\mathrm{F}$ & & & 38,31 & 35,95 & 35,09 & 36,45 & 37,65 & 38,49 & 38,46 & 38,20 \\
\hline 214 & 28 & B RhD- & O RhD- & M & & & ND & ND & ND & ND & ND & ND & ND & ND \\
\hline 215 & 18 & A RhD- & A RhD- & $\mathrm{F}$ & & & ND & ND & ND & ND & ND & ND & ND & ND \\
\hline 216 & 21 & O RhD- & O RhD+ & M & & & 36,40 & 34,96 & 35,01 & 35,46 & 38,20 & 38,10 & 38,20 & 38,17 \\
\hline 217 & 19 & O RhD- & O RhD- & $M$ & & & ND & ND & & ND & ND & ND & & ND \\
\hline 218 & 21 & A RhD- & A RhD+ & M & & & 35,19 & 35,22 & 35,96 & 35,46 & 38,74 & 38,19 & 38,89 & 38,61 \\
\hline 219 & 27 & O RhD- & O RhD- & $M$ & & & ND & ND & ND & ND & ND & ND & ND & ND \\
\hline 220 & 28 & A RhD- & A RhD- & $\mathrm{F}$ & & & ND & ND & ND & ND & ND & ND & ND & ND \\
\hline
\end{tabular}




\begin{tabular}{|c|c|c|c|c|c|c|c|c|c|c|c|c|c|}
\hline AMOSTRA & IG & $\begin{array}{c}\text { TS } \\
\text { MATERNA }\end{array}$ & $\begin{array}{c}\text { TS } \\
\text { RN1 }\end{array}$ & $\begin{array}{l}\text { SEXO } \\
\text { RN1 }\end{array}$ & TS RN2 & $\begin{array}{l}\text { SEXO } \\
\text { RN2 }\end{array}$ & $\begin{array}{c}\text { CCR5 } \\
1\end{array}$ & $\begin{array}{c}\text { CCR5 } \\
2\end{array}$ & $\begin{array}{l}\text { CCR5 } \\
\text { Média }\end{array}$ & $\begin{array}{c}R H D \Psi \\
1\end{array}$ & $\begin{array}{c}R H D \Psi \\
2\end{array}$ & $\begin{array}{c}R H D \Psi \\
3\end{array}$ & 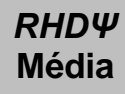 \\
\hline 2 & 23 & O RhD- & O RhD- & $\mathrm{M}$ & & & 34,72 & 34,39 & 34,55 & 25,80 & 25,50 & 25,48 & 25,59 \\
\hline 7 & 28 & O RhD- & O RhD- & $M$ & O RhD- & $\mathrm{F}$ & 35,21 & 35,56 & 35,39 & & & & \\
\hline 11 & 25 & A RhD- & O RhD+ & $M$ & & & 36,26 & 35,69 & 35,98 & & & & \\
\hline 13 & 22 & O RhD- & O RhD- & $\mathrm{F}$ & & & 34,48 & 35,45 & 34,97 & & & & \\
\hline 14 & 20 & O RhD- & O RhD+ & $\mathrm{F}$ & & & 35,97 & 34,96 & 35,47 & & & & \\
\hline 15 & 13 & O RhD- & B RhD- & $\mathrm{F}$ & & & 35,68 & 36,24 & 35,96 & & & & \\
\hline 16 & 27 & O RhD- & O RhD+ & $\mathrm{F}$ & & & 36,69 & 37,20 & 36,95 & & & & \\
\hline 18 & 27 & B RhD- & A RhD+ & $M$ & & & 36,44 & 35,71 & 36,08 & & & & \\
\hline 24 & 15 & O RhD- & O RhD- & $\mathrm{F}$ & O RhD- & $\mathrm{F}$ & 34,09 & 33,91 & 34,00 & & & & \\
\hline 25 & 23 & O RhD- & O RhD+ & $\mathrm{F}$ & & & 34,27 & 33,76 & 34,02 & & & & \\
\hline 26 & 16 & O RhD- & O RhD+ & $\mathrm{M}$ & & & 35,62 & 36,02 & 35,82 & & & & \\
\hline 28 & 12 & O RhD- & O RhD- & $\mathrm{M}$ & & & 37,90 & & 37,90 & & & & \\
\hline 31 & 24 & B RhD- & B RhD- & $\mathrm{F}$ & & & 36,42 & 36,97 & 36,69 & 22,28 & 22,26 & 22,37 & 22,30 \\
\hline 32 & 19 & A RhD- & A RhD+ & $\mathrm{F}$ & & & 35,10 & 35,58 & 35,34 & & & & \\
\hline 34 & 27 & O RhD- & O RhD+ & $\mathrm{F}$ & & & 34,87 & 34,82 & 34,85 & & & & \\
\hline 36 & 16 & B RhD- & B RhD+ & $\mathrm{F}$ & & & 36,61 & 35,49 & 36,05 & & & & \\
\hline 39 & 21 & A RhD- & A RhD+ & $\mathrm{M}$ & & & 33,76 & 33,46 & 33,61 & & & & \\
\hline 41 & 25 & B RhD- & B RhD+ & $\mathrm{F}$ & & & 34,08 & 34,23 & 34,16 & & & & \\
\hline 42 & 28 & B RhD- & O RhD- & $\mathrm{F}$ & & & 34,98 & 33,96 & 34,47 & & & & \\
\hline 43 & 13 & A RhD- & A RhD+ & $\mathrm{F}$ & & & 33,16 & & 33,16 & & & & \\
\hline 44 & 28 & O RhD- & A RhD+ & $\mathrm{F}$ & & & 32,98 & & 32,98 & & & & \\
\hline 45 & 21 & A RhD- & O RhD+ & $\mathrm{M}$ & & & 33,12 & 33,45 & 33,28 & & & & \\
\hline 46 & 17 & B RhD- & O RhD+ & $M$ & & & 35,49 & 34,98 & 35,24 & & & & \\
\hline 47 & 23 & A RhD- & A RhD- & $\mathrm{M}$ & & & 35,37 & 35,54 & 35,45 & & & & \\
\hline
\end{tabular}




\begin{tabular}{|c|c|c|c|c|c|c|c|c|c|c|c|c|c|}
\hline AMOSTRA & IG & $\begin{array}{c}\text { TS } \\
\text { MATERNA }\end{array}$ & $\begin{array}{c}\text { TS } \\
\text { RN1 } \\
\end{array}$ & $\begin{array}{l}\text { SEXO } \\
\text { RN1 }\end{array}$ & TS RN2 & $\begin{array}{l}\text { SEXO } \\
\text { RN2 }\end{array}$ & $\begin{array}{c}\text { CCR5 } \\
1 \\
\end{array}$ & $\begin{array}{c}\text { CCR5 } \\
2 \\
\end{array}$ & $\begin{array}{l}\text { CCR5 } \\
\text { Média }\end{array}$ & $\begin{array}{c}\text { RHD } \Psi \\
1 \\
\end{array}$ & $\begin{array}{c}\text { RHD } \Psi \\
2 \\
\end{array}$ & $\begin{array}{c}\text { RHD } \Psi \\
3 \\
\end{array}$ & $\begin{array}{l}\text { RHDU } \\
\text { Média }\end{array}$ \\
\hline 48 & 28 & AB RhD- & B RhD+ & $\mathrm{M}$ & & & 34,45 & 34,63 & 34,54 & & & & \\
\hline 50 & 12 & A RhD- & AB RhD+ & $\mathrm{F}$ & & & 33,37 & 33,07 & 33,22 & & & & \\
\hline 51 & 27 & O RhD- & O RhD+ & $M$ & & & 33,15 & 33,83 & 33,49 & & & & \\
\hline 52 & 27 & O RhD- & O RhD+ & $\mathrm{M}$ & & & 30,29 & 30,12 & 30,20 & & & & \\
\hline 53 & 25 & O RhD- & O RhD+ & $\mathrm{M}$ & & & 34,73 & 35,76 & 35,25 & & & & \\
\hline 54 & 12 & A RhD- & A RhD+ & $\mathrm{M}$ & & & 32,38 & 33,09 & 32,73 & & & & \\
\hline 55 & 13 & O RhD- & O RhD+ & $\mathrm{F}$ & & & 35,75 & 35,67 & 35,71 & & & & \\
\hline 56 & 19 & B RhD- & O RhD+ & $\mathrm{F}$ & & & 35,03 & 34,95 & 34,99 & & & & \\
\hline 57 & 10 & A RhD- & O RhD+ & $\mathrm{M}$ & & & 35,95 & 35,83 & 35,89 & & & & \\
\hline 58 & 21 & AB RhD- & B RhD- & $\mathrm{F}$ & & & 34,75 & 34,90 & 34,83 & & & & \\
\hline 59 & 10 & AB RhD- & A RhD+ & $\mathrm{F}$ & & & 34,06 & 33,94 & 34,00 & & & & \\
\hline 60 & 23 & A RhD- & O RhD+ & $\mathrm{M}$ & & & 33,45 & 33,58 & 33,52 & & & & \\
\hline 61 & 23 & A RhD- & A RhD+ & $\mathrm{M}$ & & & 34,84 & 34,62 & 34,73 & & & & \\
\hline 62 & 22 & O RhD- & A RhD+ & $\mathrm{M}$ & & & 35,45 & 35,46 & 35,46 & & & & \\
\hline 63 & 18 & O RhD- & B RhD+ & $\mathrm{F}$ & & & 35,35 & 34,96 & 35,15 & & & & \\
\hline 64 & 15 & A RhD- & A RhD+ & $\mathrm{M}$ & & & 36,27 & 35,66 & 35,96 & & & & \\
\hline 65 & 27 & O RhD- & O RhD+ & $M$ & & & 36,96 & 38,48 & 37,72 & & & & \\
\hline 66 & 25 & O RhD- & A RhD+ & $M$ & & & 35,76 & 36,14 & 35,95 & & & & \\
\hline 67 & 16 & O RhD- & O RhD+ & $M$ & & & 37,32 & 37,52 & 37,42 & & & & \\
\hline 68 & 23 & O RhD- & O RhD+ & $\mathrm{F}$ & & & 35,06 & 34,40 & 34,73 & & & & \\
\hline 70 & 19 & O RhD- & O RhD- & $\mathrm{F}$ & & & 36,24 & 36,16 & 36,20 & & & & \\
\hline 72 & 24 & O RhD- & O RhD+ & $M$ & & & 37,88 & 35,80 & 36,84 & & & & \\
\hline 73 & 22 & A RhD- & A RhD- & $M$ & & & 35,62 & 35,43 & 35,53 & & & & \\
\hline 74 & 20 & O RhD- & B RhD- & $M$ & & & 33,99 & 34,02 & 34,01 & & & & \\
\hline 75 & 28 & O RhD- & O RhD+ & $\mathrm{F}$ & & & 34,06 & 33,97 & 34,02 & & & & \\
\hline 76 & 12 & O RhD- & O RhD+ & $\mathrm{M}$ & & & 34,37 & 34,33 & 34,35 & & & & \\
\hline 77 & 19 & B RhD- & O RhD- & $\mathrm{F}$ & & & 34,67 & 34,45 & 34,56 & & & & \\
\hline
\end{tabular}




\begin{tabular}{|c|c|c|c|c|c|c|c|c|c|c|c|c|c|}
\hline AMOSTRA & IG & $\begin{array}{c}\text { TS } \\
\text { MATERNA }\end{array}$ & $\begin{array}{c}\text { TS } \\
\text { RN1 } \\
\end{array}$ & $\begin{array}{l}\text { SEXO } \\
\text { RN1 }\end{array}$ & TS RN2 & $\begin{array}{l}\text { SEXO } \\
\text { RN2 }\end{array}$ & $\begin{array}{c}\text { CCR5 } \\
1 \\
\end{array}$ & $\begin{array}{c}\text { CCR5 } \\
2 \\
\end{array}$ & $\begin{array}{l}\text { CCR5 } \\
\text { Média }\end{array}$ & $\begin{array}{c}\text { RHD } \Psi \\
1 \\
\end{array}$ & $\begin{array}{c}\text { RHD } \Psi \\
2 \\
\end{array}$ & $\begin{array}{c}\text { RHD } \Psi \\
3 \\
\end{array}$ & $\begin{array}{l}\text { RHDU } \\
\text { Média }\end{array}$ \\
\hline 78 & 27 & O RhD- & O RhD- & $\mathrm{M}$ & & & 32,43 & 32,28 & 32,35 & & & & \\
\hline 79 & 16 & O RhD- & O RhD+ & $\mathrm{F}$ & & & 37,09 & 36,93 & 37,01 & & & & \\
\hline 80 & 13 & O RhD- & A RhD+ & $\mathrm{M}$ & & & 35,21 & 35,32 & 35,26 & & & & \\
\hline 81 & 13 & A RhD- & A RhD+ & $\mathrm{M}$ & & & 34,31 & 34,56 & 34,44 & & & & \\
\hline 82 & 11 & O RhD- & O RhD+ & $\mathrm{F}$ & & & 34,10 & 34,22 & 34,16 & & & & \\
\hline 83 & 17 & A RhD- & O RhD+ & $\mathrm{F}$ & & & 35,34 & 36,50 & 35,92 & & & & \\
\hline 84 & 23 & B RhD- & O RhD- & $M$ & & & 36,57 & 35,90 & 36,23 & & & & \\
\hline 85 & 25 & B RhD- & O RhD+ & $\mathrm{M}$ & & & 34,84 & 34,83 & 34,84 & & & & \\
\hline 86 & 28 & B RhD- & B RhD- & $\mathrm{F}$ & & & 33,49 & 33,64 & 33,56 & & & & \\
\hline 87 & 26 & O RhD- & O RhD+ & $\mathrm{M}$ & O RhD+ & $\mathrm{M}$ & 34,80 & 35,39 & 35,09 & & & & \\
\hline 88 & 24 & A RhD- & A RhD+ & $\mathrm{F}$ & & & 35,48 & 35,64 & 35,56 & & & & \\
\hline 89 & 27 & O RhD- & O RhD+ & $\mathrm{M}$ & & & 34,24 & 34,27 & 34,25 & & & & \\
\hline 90 & 9 & O RhD- & B RhD- & $M$ & & & 37,27 & 36,59 & 36,93 & & & & \\
\hline 91 & 25 & A RhD- & A RhD+ & $M$ & & & 37,96 & & 37,96 & & & & \\
\hline 92 & 22 & O RhD- & O RhD- & $\mathrm{M}$ & & & 36,37 & & 36,37 & & & & \\
\hline 93 & 27 & O RhD- & O RhD+ & $\mathrm{F}$ & & & 34,05 & & 34,05 & & & & \\
\hline 94 & 24 & AB RhD- & B RhD+ & $M$ & & & 34,02 & & 34,02 & & & & \\
\hline 95 & 7 & B RhD- & B RhD- & $\mathrm{F}$ & & & 34,97 & & 34,97 & & & & \\
\hline 96 & 21 & A RhD- & AB RhD- & $M$ & & & 34,46 & 34,36 & 34,41 & 24,37 & 24,62 & 24,94 & 24,64 \\
\hline 97 & 22 & A RhD- & A RhD+ & $\mathrm{M}$ & & & 34,44 & & 34,44 & & & & \\
\hline 98 & 20 & O RhD- & O RhD- & $\mathrm{F}$ & & & 34,15 & & 34,15 & & & & \\
\hline 99 & 21 & B RhD- & B RhD+ & $\mathrm{F}$ & & & 35,04 & & 35,04 & & & & \\
\hline 100 & 9 & O RhD- & O RhD+ & $M$ & & & 36,02 & & 36,02 & & & & \\
\hline 101 & 17 & O RhD- & A RhD- & $\mathrm{M}$ & & & 36,74 & & 36,74 & & & & \\
\hline 102 & 20 & A RhD- & A RhD- & $\mathrm{F}$ & A RhD- & $M$ & 37,94 & & 37,94 & & & & \\
\hline 103 & 25 & O RhD- & A RhD- & $M$ & & & 35,16 & & 35,16 & & & & \\
\hline 104 & 27 & A RhD- & A RhD+ & $M$ & & & 29,92 & & 29,92 & & & & \\
\hline
\end{tabular}




\begin{tabular}{|c|c|c|c|c|c|c|c|c|c|c|c|c|c|}
\hline AMOSTRA & IG & $\begin{array}{c}\text { TS } \\
\text { MATERNA }\end{array}$ & $\begin{array}{c}\text { TS } \\
\text { RN1 } \\
\end{array}$ & $\begin{array}{c}\text { SEXO } \\
\text { RN1 }\end{array}$ & $\begin{array}{c}\text { TS } \\
\text { RN2 } \\
\end{array}$ & $\begin{array}{l}\text { SEXO } \\
\text { RN2 }\end{array}$ & $\begin{array}{c}\text { CCR5 } \\
1 \\
\end{array}$ & $\begin{array}{c}\text { CCR5 } \\
2 \\
\end{array}$ & $\begin{array}{l}\text { CCR5 } \\
\text { Média }\end{array}$ & $\begin{array}{c}\text { RHD } \Psi \\
1 \\
\end{array}$ & $\begin{array}{c}\text { RHD } \Psi \\
2 \\
\end{array}$ & $\begin{array}{c}\text { RHD } \Psi \\
3 \\
\end{array}$ & $\begin{array}{l}\text { RHDU } \\
\text { Média }\end{array}$ \\
\hline 105 & 15 & O RhD- & O RhD- & $\mathrm{M}$ & & & 34,79 & & 34,79 & & & & \\
\hline 106 & 27 & O RhD- & O RhD+ & $\mathrm{F}$ & & & 33,70 & & 33,70 & & & & \\
\hline 107 & 27 & A RhD- & A RhD+ & $\mathrm{F}$ & & & 40,13 & & 40,13 & & & & \\
\hline 108 & 26 & B RhD- & B RhD+ & $\mathrm{M}$ & & & 37,17 & & 37,17 & & & & \\
\hline 110 & 27 & B RhD- & B RhD+ & $\mathrm{M}$ & & & 31,36 & 34,29 & 32,82 & & & & \\
\hline 111 & 17 & A RhD- & O RhD+ & $\mathrm{M}$ & & & 37,46 & 36,67 & 37,06 & & & & \\
\hline 112 & 9 & O RhD- & O RhD+ & $\mathrm{F}$ & & & 35,62 & 36,04 & 35,83 & & & & \\
\hline 113 & 19 & B RhD- & O RhD+ & $\mathrm{M}$ & & & 36,32 & 35,83 & 36,08 & & & & \\
\hline 114 & 13 & O RhD- & O RhD- & $M$ & & & 35,80 & & 35,80 & & & & \\
\hline 115 & 21 & O RhD- & B RhD+ & $\mathrm{F}$ & & & 35,47 & & 35,47 & & & & \\
\hline 116 & 23 & B RhD- & A RhD+ & $\mathrm{F}$ & & & 44,60 & 45,33 & 44,96 & & & & \\
\hline 117 & 18 & O RhD- & O RhD+ & $\mathrm{F}$ & & & 33,62 & 32,96 & 33,29 & & & & \\
\hline 118 & 28 & A RhD- & A RhD+ & $\mathrm{F}$ & & & 34,20 & 34,89 & 34,55 & & & & \\
\hline 119 & 11 & O RhD- & O RhD+ & $\mathrm{F}$ & & & 36,98 & 36,36 & 36,67 & & & & \\
\hline 120 & 15 & B RhD- & B RhD- & $\mathrm{M}$ & & & 33,78 & 34,05 & 33,91 & & & & \\
\hline 121 & 12 & O RhD- & O RhD+ & $\mathrm{F}$ & & & 35,56 & 35,80 & 35,68 & & & & \\
\hline 122 & 24 & O RhD- & O RhD+ & $\mathrm{F}$ & & & 34,61 & 34,63 & 34,62 & & & & \\
\hline 124 & 27 & O RhD- & O RhD+ & $\mathrm{F}$ & & & 34,84 & 35,07 & 34,96 & & & & \\
\hline 125 & 27 & O RhD- & O RhD+ & $\mathrm{F}$ & & & 36,14 & 36,91 & 36,52 & & & & \\
\hline 126 & 20 & A RhD- & A RhD+ & $\mathrm{M}$ & & & 39,00 & 40,15 & 39,58 & & & & \\
\hline 127 & 28 & O RhD- & O RhD+ & $M$ & & & 34,68 & 34,39 & 34,54 & & & & \\
\hline 128 & 24 & A RhD- & A RhD+ & $\mathrm{F}$ & & & 35,19 & 35,80 & 35,50 & & & & \\
\hline 130 & 13 & AB RhD- & A RhD- & $M$ & & & 35,12 & 34,30 & 34,71 & & & & \\
\hline 131 & 23 & O RhD- & A RhD- & $M$ & & & 36,51 & 35,49 & 36,00 & & & & \\
\hline 132 & 28 & A RhD- & A RhD+ & $\mathrm{M}$ & & & 37,22 & 37,43 & 37,33 & & & & \\
\hline 133 & 12 & A RhD- & O RhD+ & $\mathrm{F}$ & & & 37,62 & 37,24 & 37,43 & & & & \\
\hline 134 & 12 & O RhD- & O RhD- & $\mathrm{F}$ & & & 37,26 & 37,25 & 37,26 & & & & \\
\hline
\end{tabular}




\begin{tabular}{|c|c|c|c|c|c|c|c|c|c|c|c|c|c|}
\hline AMOSTRA & IG & $\begin{array}{c}\text { TS } \\
\text { MATERNA }\end{array}$ & $\begin{array}{c}\text { TS } \\
\text { RN1 }\end{array}$ & $\begin{array}{c}\text { SEXO } \\
\text { RN1 }\end{array}$ & $\begin{array}{c}\text { TS } \\
\text { RN2 }\end{array}$ & $\begin{array}{c}\text { SEXO } \\
\text { RN2 }\end{array}$ & $\begin{array}{c}\text { CCR5 } \\
1 \\
\end{array}$ & $\begin{array}{c}\text { CCR5 } \\
2 \\
\end{array}$ & $\begin{array}{l}\text { CCR5 } \\
\text { Média } \\
\end{array}$ & $\begin{array}{c}R H D \Psi \\
1 \\
\end{array}$ & $\begin{array}{c}R H D \Psi \\
2 \\
\end{array}$ & $\begin{array}{c}\text { RHD } \Psi \\
3 \\
\end{array}$ & 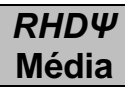 \\
\hline 135 & 23 & O RhD- & A RhD- & $\mathrm{M}$ & & & 37,76 & 37,87 & 37,81 & & & & \\
\hline 136 & 28 & O RhD- & A RhD- & $M$ & A RhD- & $\mathrm{M}$ & 38,95 & & 38,95 & & & & \\
\hline 137 & 22 & O RhD- & O RhD- & $\mathrm{F}$ & & & 37,24 & 38,00 & 37,62 & & & & \\
\hline 138 & 24 & O RhD- & O RhD+ & $\mathrm{F}$ & ORhD+ & $\mathrm{F}$ & 30,54 & 30,44 & 30,49 & & & & \\
\hline 139 & 26 & O RhD- & A RhD+ & $M$ & & & 33,71 & 33,65 & 33,68 & & & & \\
\hline 140 & 19 & A RhD- & A RhD- & $\mathrm{F}$ & & & 31,34 & 31,89 & 31,61 & & & & \\
\hline 141 & 11 & O RhD- & A RhD- & $M$ & & & 33,54 & 33,32 & 33,43 & & & & \\
\hline 142 & 20 & O RhD- & O RhD+ & $\mathrm{M}$ & & & 35,05 & 35,57 & 35,31 & & & & \\
\hline 143 & 28 & O RhD- & O RhD+ & $M$ & & & 35,46 & 35,55 & 35,50 & & & & \\
\hline 144 & 22 & A RhD- & A RhD+ & $\mathrm{F}$ & & & 31,96 & 31,87 & 31,91 & & & & \\
\hline 146 & 12 & O RhD- & A RhD+ & $\mathrm{F}$ & & & 34,74 & 34,87 & 34,80 & & & & \\
\hline 147 & 10 & O RhD- & O RhD- & $\mathrm{F}$ & & & 36,87 & 36,78 & 36,83 & & & & \\
\hline 148 & 25 & A RhD- & A RhD- & $\mathrm{F}$ & & & 35,43 & 35,46 & 35,44 & & & & \\
\hline 149 & 11 & O RhD- & A RhD+ & $\mathrm{F}$ & & & 36,01 & 36,50 & 36,26 & & & & \\
\hline 150 & 22 & A RhD- & A RhD+ & $\mathrm{F}$ & & & 35,11 & 35,52 & 35,31 & & & & \\
\hline 151 & 12 & O RhD- & A RhD- & $\mathrm{F}$ & & & 36,19 & 36,75 & 36,47 & & & & \\
\hline 152 & 13 & A RhD- & A RhD- & $\mathrm{F}$ & & & 35,50 & 35,39 & 35,44 & 22,59 & 23,05 & 22,43 & 22,69 \\
\hline 153 & 19 & A RhD- & A RhD+ & $M$ & & & 35,78 & 35,75 & 35,76 & & & & \\
\hline 154 & 26 & O RhD- & O RhD+ & $M$ & & & 32,68 & 32,91 & 32,80 & & & & \\
\hline 155 & 19 & B RhD- & AB RhD- & $\mathrm{M}$ & & & 36,48 & 35,42 & 35,95 & & & & \\
\hline 157 & 14 & O RhD- & A RhD+ & $M$ & & & 35,64 & 35,51 & 35,57 & & & & \\
\hline 158 & 19 & B RhD- & A RhD- & $M$ & & & 34,51 & 34,49 & 34,50 & & & & \\
\hline 159 & 18 & AB RhD- & B RhD+ & $\mathrm{F}$ & & & 33,32 & 34,35 & 33,83 & & & & \\
\hline 160 & 16 & A RhD- & AB RhD- & $M$ & & & 35,96 & 35,18 & 35,57 & 20,97 & 21,47 & 21,47 & 21,30 \\
\hline 161 & 14 & O RhD- & O RhD+ & $\mathrm{F}$ & O RhD- & $\mathrm{F}$ & 34,74 & 34,91 & 34,83 & & & & \\
\hline 162 & 28 & A RhD- & AB RhD+ & $M$ & & & 35,46 & 35,74 & 35,60 & & & & \\
\hline 163 & 17 & O RhD- & O RhD+ & $\mathrm{F}$ & & & 34,83 & 34,96 & 34,89 & & & & \\
\hline
\end{tabular}




\begin{tabular}{|c|c|c|c|c|c|c|c|c|c|c|c|c|c|}
\hline AMOSTRA & IG & $\begin{array}{c}\text { TS } \\
\text { MATERNA }\end{array}$ & TS RN1 & $\begin{array}{c}\text { SEXO } \\
\text { RN1 }\end{array}$ & TS RN2 & $\begin{array}{c}\text { SEXO } \\
\text { RN2 } \\
\end{array}$ & $\begin{array}{c}\text { CCR5 } \\
1 \\
\end{array}$ & $\begin{array}{c}\text { CCR5 } \\
2 \\
\end{array}$ & $\begin{array}{l}\text { CCR5 } \\
\text { Média }\end{array}$ & $\begin{array}{c}R H D \Psi \\
1\end{array}$ & $\begin{array}{c}\text { RHDU } \\
2 \\
\end{array}$ & $\begin{array}{c}\text { RHDW } \\
3 \\
\end{array}$ & $\begin{array}{l}\text { RHD } \Psi \\
\text { Média }\end{array}$ \\
\hline 164 & 26 & AB RhD- & A RhD+ & $\mathrm{M}$ & & & 36,32 & 36,03 & 36,17 & & & & \\
\hline 165 & 16 & O RhD- & O RhD+ & $\mathrm{F}$ & & & 34,98 & 34,68 & 34,83 & & & & \\
\hline 166 & 19 & O RhD- & O RhD+ & $\mathrm{F}$ & & & 31,22 & 31,50 & 31,36 & & & & \\
\hline 168 & 12 & A RhD- & A RhD+ & $M$ & & & 32,13 & & 32,13 & & & & \\
\hline 169 & 8 & B RhD- & O RhD+ & $M$ & & & 34,51 & 34,70 & 34,60 & & & & \\
\hline 170 & 8 & O RhD- & O RhD+ & $M$ & & & 36,15 & 36,11 & 36,13 & & & & \\
\hline 171 & 16 & O RhD- & O RhD+ & $\mathrm{F}$ & & & 31,23 & 31,32 & 31,28 & & & & \\
\hline 172 & 16 & A RhD- & A RhD- & $M$ & & & 35,55 & 39,10 & 37,33 & & & & \\
\hline 173 & 18 & A RhD- & A RhD+ & $M$ & & & 33,52 & 33,53 & 33,53 & & & & \\
\hline 174 & 24 & O RhD- & O RhD+ & $\mathrm{F}$ & & & 32,16 & 32,11 & 32,14 & & & & \\
\hline 175 & 26 & AB RhD- & A RhD+ & $M$ & & & 34,15 & 33,89 & 34,02 & & & & \\
\hline 176 & 24 & B RhD- & B RhD+ & $M$ & & & 34,34 & 34,97 & 34,65 & & & & \\
\hline 177 & 28 & O RhD- & O RhD+ & $\mathrm{F}$ & & & 31,46 & 31,35 & 31,41 & & & & \\
\hline 178 & 20 & O RhD- & O RhD+ & $\mathrm{F}$ & & & 33,79 & 33,25 & 33,52 & & & & \\
\hline 179 & 24 & A RhD- & A RhD+ & $M$ & & & 35,35 & 34,98 & 35,17 & & & & \\
\hline 180 & 19 & AB RhD- & B RhD+ & $\mathrm{F}$ & & & 36,22 & & 36,22 & & & & \\
\hline 181 & 27 & O RhD- & O RhD+ & $M$ & & & 33,98 & & 33,98 & & & & \\
\hline 182 & 24 & A RhD- & A RhD- & $\mathrm{F}$ & & & 31,52 & & 31,52 & & & & \\
\hline 183 & 22 & O RhD- & O RhD+ & $M$ & & & 33,55 & & 33,55 & & & & \\
\hline 184 & 24 & A RhD- & A RhD+ & $M$ & & & 34,74 & & 34,74 & & & & \\
\hline 185 & 17 & O RhD- & A RhD+ & $\mathrm{F}$ & & & 33,90 & & 33,90 & & & & \\
\hline 186 & 26 & AB RhD- & B RhD+ & $M$ & & & 38,35 & & 38,35 & & & & \\
\hline 187 & 22 & O RhD- & O RhD+ & $M$ & & & 31,59 & & 31,59 & & & & \\
\hline 188 & 24 & O RhD- & O RhD+ & $M$ & & & 32,51 & 31,77 & 32,14 & & & & \\
\hline 189 & 21 & A RhD- & B RhD+ & $\mathrm{F}$ & & & 31,61 & 31,54 & 31,57 & ND & ND & & ND \\
\hline 190 & 24 & A RhD- & O RhD+ & $\mathrm{F}$ & & & 31,81 & 31,79 & 31,80 & & & & \\
\hline 191 & 28 & A RhD- & A RhD- & $\mathrm{F}$ & & & 33,53 & 33,69 & 33,61 & & & & \\
\hline
\end{tabular}




\begin{tabular}{|c|c|c|c|c|c|c|c|c|c|c|c|c|c|}
\hline AMOSTRA & IG & $\begin{array}{c}\text { TS } \\
\text { MATERNA }\end{array}$ & TS RN1 & $\begin{array}{c}\text { SEXO } \\
\text { RN1 }\end{array}$ & TS RN2 & $\begin{array}{l}\text { SEXO } \\
\text { RN2 }\end{array}$ & $\begin{array}{c}\text { CCR5 } \\
1 \\
\end{array}$ & $\begin{array}{c}\text { CCR5 } \\
2 \\
\end{array}$ & $\begin{array}{l}\text { CCR5 } \\
\text { Média }\end{array}$ & $\begin{array}{c}\text { RHD } \Psi \\
1 \\
\end{array}$ & $\begin{array}{c}\text { RHD } \Psi \\
2 \\
\end{array}$ & $\begin{array}{c}\text { RHD } \Psi \\
3 \\
\end{array}$ & $\begin{array}{l}\text { RHD } \Psi \\
\text { Média }\end{array}$ \\
\hline 192 & 23 & O RhD- & A RhD+ & $\mathrm{F}$ & A RhD+ & $\mathrm{F}$ & 32,64 & 32,81 & 32,73 & & & & \\
\hline 194 & 10 & A RhD- & A RhD+ & $M$ & & & 32,62 & 32,53 & 32,57 & & & & \\
\hline 195 & 18 & O RhD- & O RhD+ & $\mathrm{F}$ & & & 32,89 & 33,42 & 33,15 & & & & \\
\hline 196 & 21 & A RhD- & O RhD+ & $\mathrm{M}$ & & & 33,86 & 33,43 & 33,64 & & & & \\
\hline 198 & 21 & O RhD- & O RhD+ & $\mathrm{F}$ & & & 36,28 & 35,12 & 35,70 & & & & \\
\hline 199 & 16 & B RhD- & B RhD- & $\mathrm{M}$ & & & 35,53 & 35,30 & 35,42 & & & & \\
\hline 200 & 27 & A RhD- & O RhD+ & $\mathrm{F}$ & & & 35,09 & 35,32 & 35,21 & & & & \\
\hline 201 & 21 & A RhD- & A RhD- & $\mathrm{F}$ & & & 35,40 & 34,97 & 35,18 & & & & \\
\hline 202 & 22 & A RhD- & O RhD+ & $\mathrm{F}$ & & & 35,68 & 35,71 & 35,70 & & & & \\
\hline 203 & 22 & O RhD- & O RhD- & $\mathrm{F}$ & & & 36,01 & 36,03 & 36,02 & & & & \\
\hline 204 & 20 & B RhD- & B RhD+ & $\mathrm{M}$ & & & 33,58 & 33,80 & 33,69 & & & & \\
\hline 205 & 18 & O RhD- & O RhD+ & $\mathrm{F}$ & & & 32,70 & 32,82 & 32,76 & & & & \\
\hline 206 & 14 & O RhD- & O RhD+ & $\mathrm{F}$ & & & 31,52 & 31,73 & 31,63 & & & & \\
\hline 208 & 28 & O RhD- & O RhD+ & $\mathrm{F}$ & & & 33,25 & 32,84 & 33,05 & & & & \\
\hline 209 & 25 & A RhD- & O RhD+ & $M$ & & & 29,32 & 28,78 & 29,05 & ND & ND & & ND \\
\hline 210 & 22 & O RhD- & O RhD- & $\mathrm{F}$ & & & 32,55 & 32,61 & 32,58 & & & & \\
\hline 211 & 20 & A RhD- & A RhD+ & $M$ & & & 32,71 & 33,36 & 33,04 & & & & \\
\hline 212 & 16 & O RhD- & O RhD+ & $M$ & & & 31,90 & 31,74 & 31,82 & & & & \\
\hline 213 & 20 & B RhD- & A RhD+ & $\mathrm{F}$ & & & 33,84 & 33,56 & 33,70 & & & & \\
\hline 214 & 28 & B RhD- & O RhD- & $M$ & & & 32,78 & 33,09 & 32,93 & & & & \\
\hline 215 & 18 & A RhD- & A RhD- & $\mathrm{F}$ & & & 32,66 & 33,38 & 33,02 & & & & \\
\hline 216 & 21 & O RhD- & O RhD+ & $M$ & & & 32,40 & 32,13 & 32,27 & & & & \\
\hline 217 & 19 & O RhD- & O RhD- & $M$ & & & 33,71 & 33,59 & 33,65 & & & & \\
\hline 218 & 21 & A RhD- & A RhD+ & $M$ & & & 32,68 & 32,83 & 32,76 & & & & \\
\hline 219 & 27 & O RhD- & O RhD- & $M$ & & & 33,38 & 32,79 & 33,09 & & & & \\
\hline 220 & 28 & A RhD- & A RhD- & $\mathrm{F}$ & & & 33,31 & 33,53 & 33,42 & & & & \\
\hline
\end{tabular}

